\title{
MOSSES AND LIVERWORTS
}

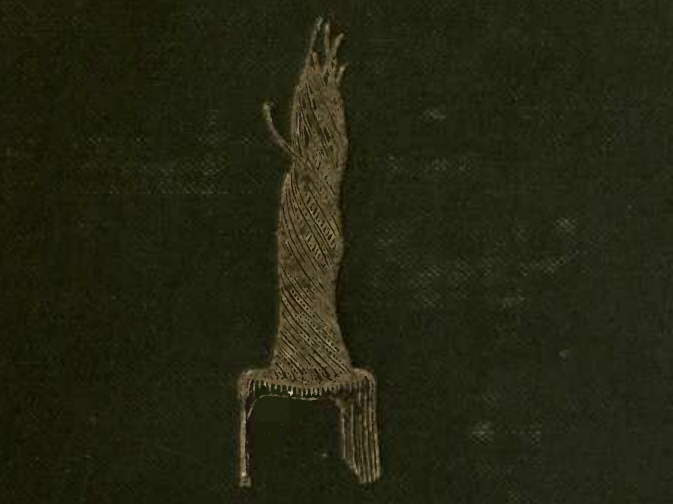

NEW \& REVISED EDITION

$$
T \cdot H \cdot R U S S E L L
$$




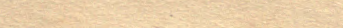

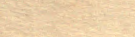

. 


\section{MOSSES AND LIVERWORTS}





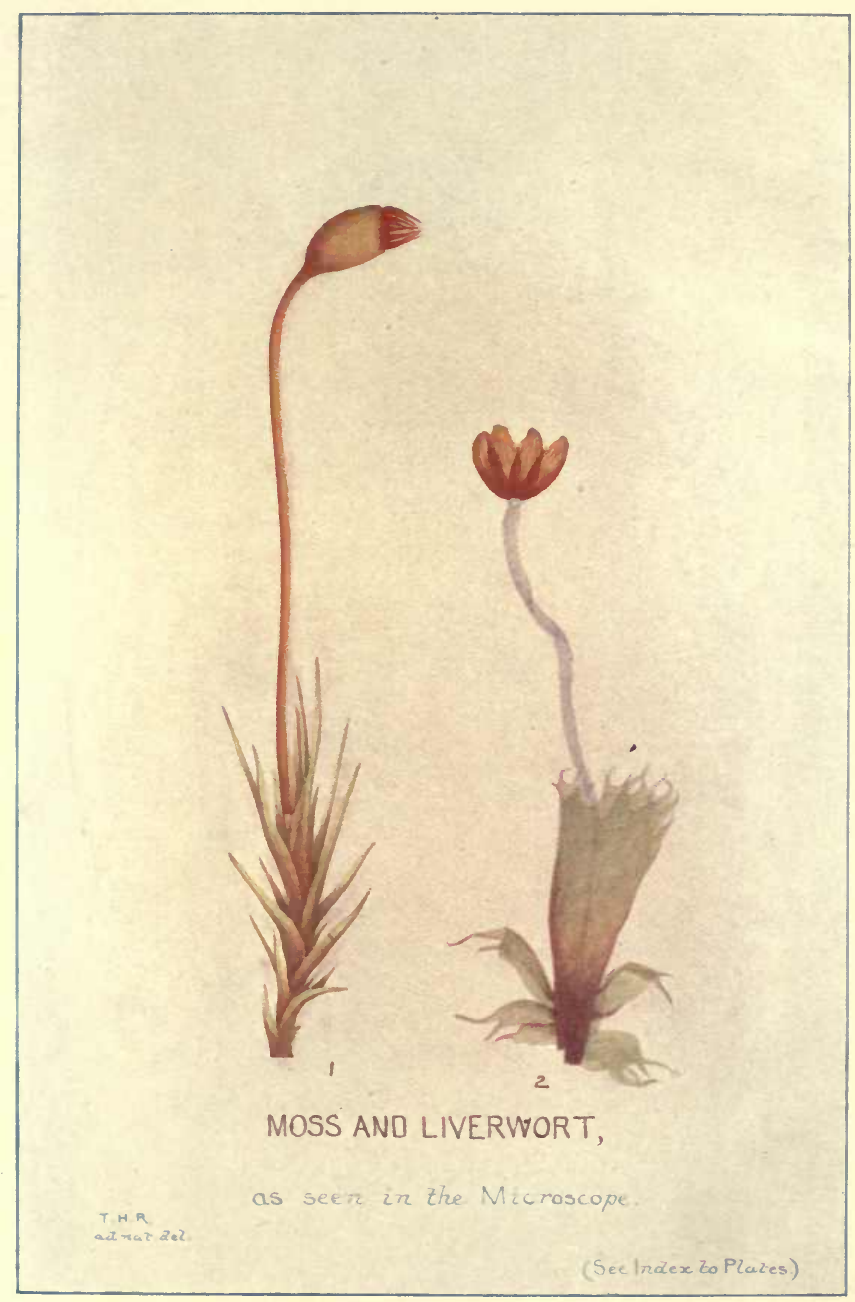




\section{MOSSES AND LIVERWORTS}

AN INTRODUCTION TO THEIR STUDY, WITH HINTS AS TO THEIR COLLECTION AND

PRESERVATION

BY

, T. H. RUSSELL, F.L.S.

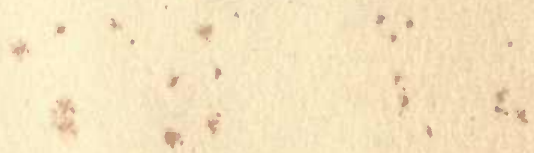

WITH ILLUSTRATIONS FROM ORTGINAL MICROSCOPICAL DRAWINGS

$$
2
$$

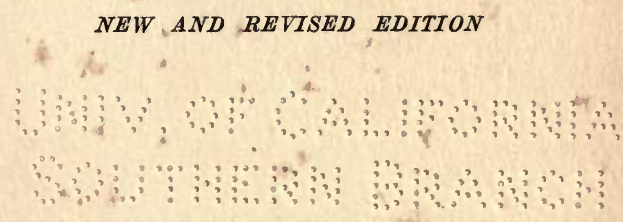

LONDON

SAMPSON LOW, MARSTON \& COMPANY, LD.

$$
\begin{gathered}
1910 \\
583^{\circ}
\end{gathered}
$$


PRINTED BY HAZELL, WATSON AND VINEY, LD., LONDON AND AYLESBURY.

3<smiles>c1ccccc1</smiles>

t.

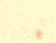




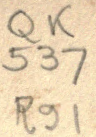

Dedication

To

\section{Y W I FE,}

THE CONSTANT COMPANION OF MY BOTANICAL RAMBLES, AND SHARER IN THE MANY HAPPY HOURS SPENT IN THE EXAMINATION OF THE SPOILS THEN OBTAINED, THE RESULTS OF WHICH ARE BUT DIMLY PORTRAYED IN THE FOLLOWING PAGES. 


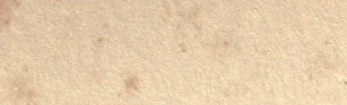

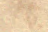
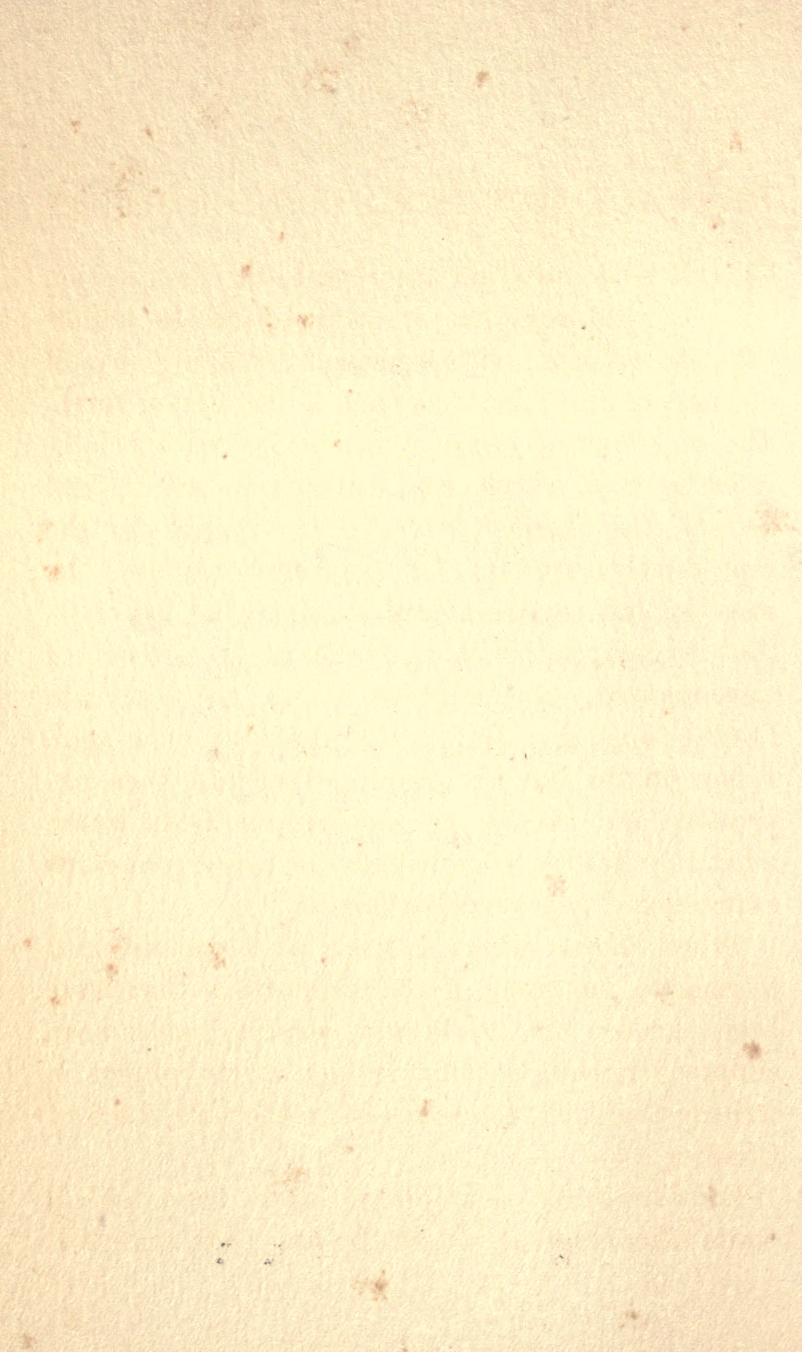


\section{PREFACE TO THE REVISED EDITION}

$7 \mathrm{HE}$ kind reception accorded to the first edition 1 of this work has emboldened me to undertake its revision, with a view to availing myself of some of the criticisms that it has called forth. The only one of these to which I need specially refer is that which was directed to my special use of the word "flowers" as applied to the reproductive organs. One so commonly uses the word in that sense-doubtless somewhat looselythat my adoption of it was, perhaps, not altogether unwarranted, especially as I am not alone in having done so. But, after what has been said, I bow to the adverse opinion that has been expressed, and in the present edition have, somewhat reluctantly, substituted the less euphonious expression "reproductive organs."

Other shortcomings I have also endeavoured to remove, but some of the suggestions that have been thrown out could not possibly have been adopted without sacrificing my prime object in writing the book, as expressed in the Introductory Chapter.

Four entirely new plates have been added, while the original Plate I. has been omitted. 


\section{viii PREFACE TO THE REVISED EDITION}

These fresh illustrations will, I think, help to still further elucidate many of the most interesting features of the subject.

I am much indebted to Mr. H. N. Dixon, M.A., for various most helpful suggestions, and for kindly advice on sundry points of doubt and difficulty.

\section{T. H. RUSSELL.}

17, Vicarage Road, Edgbaston,

BiRMiNGHAM.

July 25th, 1910. 


\section{PREFACE TO THE FIRST EDITION}

7 HE following pages have been penned in the 1 hope that, not only may they be the means of introducing the study of the little plants with the life-history of which they deal, to some who have not hitherto realised its possibilities, but may also be of service to others who, while not desirous of going at all deeply into the matter, may nevertheless wish to know something about the structure and growth of these humble members of the botanical community.

I have often observed, when lecturing to a general audience, how greatly the avoidance of scientific phraseology has been appreciated, and I feel sure that the use of even ordinary botanical terms, on such and similar occasions, is responsible for the fact that, to the lay mind, any subject connected with the world of plant life is too frequently considered as necessarily dry and uninteresting. With this in mind I have been specially anxious to use simple language, and have, therefore, in nearly every case employed English equivalents for the ordinary expressions, at the same time adding the latter in brackets. For the like reason I have given English names to the few 
species to which I refer as examples, believing, that here again, the dislike that is felt by so many to their Latin titles, might act as a deterrent if only the latter appeared. And herein has lain my chief difficulty, for there really are no truly "popular" names, for the simple reason that the plants themselves have never appealed to a democratic audience. With the Mosses I have endeavoured to make the best of the material at hand by simply adopting the English names given in Wilson's “ Bryologia Britannica," unsatisfactory as these only too often are, more especially since, in many instances, his classification has been considerably altered, so that the English term that he uses, does not now strictly correspond with the modern scientific one. With regard to the Liverworts the difficulty has lain in another direction. The most recent English names, so far as I know, are those contained in Dr. M. C. Cooke's " Guide to the British Hepaticæ," published many years ago in Science Gossip. The classification there used divides the tribe, in the first place, into three groups, to which he gives the respective generic appellations of "Scale Mosses," "Liverworts " and "Crystalworts." The first of these seems to me to be open to the inherent objection that it implies that the special plants to which it is applicable are mosses of some kind, which of course is not so. Then, although at one time, no doubt, " liverwort" was confined to a few species only, it has of late 


\section{PREFACE TO THE FIRST EDITION $x i$}

become customary to apply it to all of them indiscriminately, and consequently it seemed to me best to follow that course, while adopting Dr. Cooke's specific names.

I need hardly add that, where the serious study of these plants is undertaken, only their Latin names will be used, and that these will soon become quite familiar; but I am, of course, more especially appealing to the beginner and the uninitiated.

I must take this opportunity of acknowledging my indebtedness to my good friend, Mr. J. E. Bagnall, A.L.S., not only for numerous additions to my herbarium, and for his readiness at all times to give practical help and advice, but for his constant sympathy and encouragement, to which I owe more than I can tell in connection with the delightful study with which my book deals.

\section{T. H. RUSSELL.}

17, Vicarage Road, Edgbaston,

BirminghaM.

January 13th, 1908. 


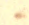

4 


\section{CONTENTS}

INTRODUCTION $. \quad . \quad$.
CHAPTER I

MOSSES

6

CHAPTER II

LIVERWORTS

CHAPTER II

\section{CHAPTER III}

BIBLIOGRAPHY $\quad . \quad$. $\quad . \quad$.

CHAPTER IV

COLLECTION AND PRESERVATION OF SPECIMENS

. 147

CHAPTER V

CONCLUSION

CHAPIER V

INDEX TO PLATES $\quad . \quad . \quad . \quad . \quad . \quad . \quad . \quad . \quad 187$

GLOSSARY OF TERMS USED . . . . . . . . . 199

$\operatorname{INDEX} \quad . \quad . \quad . \quad . \quad . \quad . \quad . \quad . \quad 205$ 


\title{
LIST OF ILLUSTRATIONS
}

\author{
FRONTISPIECE
}

A Moss AND A LIVERWort, AS SEEN IN THE MICROSCOPE

\section{PLATE I}

MOSS DEVELOPMENT, AS ILLUSTRATED BY THE PURPLE FORK-MOSS (CERATODON PURPOREOS)

(For details see Index to Plates, p. 187.)

\section{PLATE II}

EXAMPLES OF MOSS PLANTS (ABOUT FIVE AND A HALF TIMES LARGER THAN THE ORIGINALS)

(For details see Index to Plates, p. 188.)

PLATE III

ILLUSTRATIONS OF THE VARIOUS STAGES OF MOSS GROWTH, FROM THE SPORE TO THE CAPSULE

(For details see Index to Plates, p. 188.)

\section{PLATE IV}

MOSS CAPSULES, AND SUNDRY FEATURES OF MOSS STRUCTURE

(For details see Index to Plates, p. 189.)

PLATE IVa

MOSS CAPSULES, ETC.

(For details see Index to Plates, p. 190.)

PLATE IVb

MOSS CAPSULES AND PERISTOMES

(For details see Indess to Plates, p. 191.)

\section{PLATE V}

SOME OF THE VARIOUS FORMS ASSUMED BY THE PERISTOME OF A MOSS CAPSULE

(For details see Index to Plates, p. 191.) 


\title{
LIST OF ILLUSTRATIONS
}

\author{
PLATE Va \\ MOSS PERISTOMES AND PERISTOME TEETH \\ (For details see Index to Plates, p. 192.)
}

\section{PLATE VI}

ILLUSTRATIONS OF THE MANNER IN WHICH CERTAIN MOSS CAPSULES OPEN; ALSO OF VARIOUS SPECIAL MODES OF REPRODUCTION IN MOSSES, ETC.

(For details see Index to Plates, p. 192.)

\section{PLATE VII}

ILLUSTRATIONS OF MOSS LEAVES, AND THEIR CELL-STRUCTURE

(For details see Index to Plates, p. 193.)

PLATE VIII

EXAMPLES OF LIVERWORT PLANTS (ABOUT FIVE AND A HALF TIMES LARGER THAN THE ORIGINALS)

(For details see Index to Plates, p. 194.)

\section{PLATE IX}

ILLUSTRATIONS OF VARIOUS STAGES OF LIVERWORT GROWTH AND STRUCTURE, AND SPECIAL MODES OF REPRODUCTION

(For details see Index to Plates, p. 195.)

\section{PLATE $\mathrm{X}$}

ILLUSTRATIONS OF LIVERWORT LEAVES AND THEIR CELL-STRUCTURE (For details see Index to Plates, p. 196.)

N.B.-Plates I. to X. will be found at the end of the volume, immediately following page 212. 


\section{MOSSES AND LIVERWORTS}

\section{INTRODUCTION}

I WOULD venture to address what I have to say in the following pages-which attempt to give a short and simple sketch of the lifehistory of some of the smaller members of the great plant world-to those who, in the words of Longfellow,

love the haunts of nature,

Love the sunshine of the meadow,

Love the shadow of the forest,

Love the wind among the branches,

And the rain-shower, and the snow-storm,

And the rushing of great rivers,

for I am anxious to deal with my subject from the point of view of a simple lover of Nature, and, by avoiding technicalities, as far as may be, to introduce to my readers in a more attractive form than is possible in a purely scientific work, a branch of natural-history study which is full of wonder and charm. To those who have country tastes and longings, and to whom the fields and 
the hedegrows, the woods and the hills, speak in tones that are ever fresh, and that only grow in fascination as the years roll on, I cannot imagine a pursuit that will bring with it more pleasure and interest of a quiet kind, than the study of these lowly members of the botanical community. A hobby of any kind is a sure means of adding to the happiness of life; but one that, as in the present instance, may be followed out at all times and in all seasons, year in, year out; that, while giving zest to every country walk and ramble, yet provides endless occupation for the long winter evenings by the home fireside; that introduces its votaries to a world of hidden beauty, undreamt of by the casual observer, and thus, while educating the powers of observation and discrimination, gives food for pleasurable thoughts and recollections; such a hobby cannot but appeal in no uncertain voice to the ever-widening circle of natural-history lovers and workers. To those again who, while having no intention of embarking on the closer study of these little plants, are nevertheless interested in all Nature's works and ways, I trust that the story that I have to tell may not be without its attraction. For, while it is generally true that "a little learning is a dangerous thing," this caution cannot apply to the pursuit of naturalhistory, where the smallest amount of knowledge is better than none at all, increasing, as it must do, our marvel at the ways of this wondrous world, 
and thus directly adding to the interest of life. As Wordsworth has so beautifully put it:

\section{Nature never did betray}

The heart that loved her. 'Tis her privilege, Through all the years of this our life to lead From joy to joy.

It is therefore in the hope that I may be able to bring to the notice of others a pursuit which has been to me a constant source of refreshment and delight, that these pages have been written.

As the mosses are the more familiar plants, I propose to confine myself, in the first instance, to them, giving a few of the more generally interesting facts respecting them, and passing to a short sketch of their life-history, and various modes of reproduction. I shall then deal, on the same lines, with that small but fascinating tribe that comes next below the mosses in the botanical social scale, the liverworts, and shall conclude with a few practical suggestions as to the collection, examination, and preservation of specimens. I wish, however, to say most emphatically at the outset, that I do not pretend to do more than to give a broad outline of the subject, my object being, not to write a treatise of some scientific value, but to raise in others the desire for fuller information, and thus to induce them, not only to consult more advanced works, but to go to the fountain-head of knowledge, and to make 
themselves personally acquainted with these beautiful children of Nature. I have so often been asked where a simple statement of the facts of moss-life can be found that I am led to think that, notwithstanding the multitude of books on naturalhistory topics that recent years have called forth, there is even yet an opening for an unpretentious volume having the above objects in view. And I am the more anxious to make the attempt to fill the gap, because I cannot help feeling that the would-be inquirer into this particular region of plant-lore is often discouraged by the unattractive nature of ordinary botanical phraseology, and the scientific nomenclature necessarily used in more advanced works, and that he is in need of something in the nature of stepping-stones to start him on his way. I propose, therefore, as far as possible, to use English names and expressions, while, at the same time, giving the scientific equivalents for the various terms that I shall coin for my purpose. And, after all, this is really only doing at first hand what is constantly done by two steps, for the bulk of non-scientific readers, either consciously or unconsciously, make a mental translation of the technical expressions that they meet with, at all events until they have become so accustomed to them by constant use, that their meaning naturally suggests itself without the need for assistance.

A few words must be added as to the illustra- 
tions which will be found in the plates at the end of the volume. No descriptions, however vivid, will, in a matter of this kind, suffice to give such distinct impressions of the objects to be described as some delineation of them, or, better still, a glance at the originals, will afford, for here, as so often, "seeing is believing." I hope, therefore, that my drawings will not only elucidate the descriptions I shall give, but will also act as a further inducement to my readers to see for themselves the many beautiful forms which can, at best, be so inadequately represented on paper. These drawings have all been made, by means of the microscope, from specimens in my own collection, and I have, as far as possible, confined myself to plants which are most frequently to be found.

It must, however, be borne in mind that all the objects of which I have to speak are very smallsome of them, indeed, so minute as to be practically invisible to the unaided eye ; hence my drawings have to be on a large scale, in some cases between one and two hundred times larger than the originals. 


\section{CHAPTER I}

\section{MOSSES}

A S I am not writing a scientific treatise, I do not propose to begin in the orthodox fashion by attempting to give a definition of a moss, seeing that I have no desire to disgust my readers on the very threshold of the subject, by placing before them a number of dry, technical details which would, after all, be of little real service; it will be time enough, when we have made some practical acquaintance with the plants themselves, to seek for a scientific description of them. Fortunately, mosses are, as a rule, easily recognised, and a comparatively short acquaintance with them enables one, almost intuitively, to distinguish them, even in the field, from other plants ; indeed, the only members of the botanical world with which there is any danger of their being confused are some of that small tribe, as to which I shall have more to say hereafter-the liverworts. But even here it is only at first that any real difficulty is likely to arise, and after a little practice it soon becomes easy to tell at a glance whether any particular plant is a moss or a liverwort; while under the microscope, or with 
the help of an ordinary magnifying-glass, the differences of form and structure are at once apparent. It seems hardly necessary to mention that the beautiful little "Cup-moss," so frequently to be seen in the country, growing upon walls or on decaying tree-stumps, is not a moss at all, but a lichen, and thus occupies a lower position still in the scale of plant-life; while the so-called "Club-mosses" and "Stag's-horn-mosses" belong to a more highly organised tribe, and again are not true mosses. With the uninitiated the word "moss" seems to be a kind of general term, which is applied to all the smaller vegetable growths, and this, no doubt, accounts for the fact that the name is so frequently used inaccurately.

Number of Speoies.-But although most people know a moss when they see one, very few have any conception of the large number of different kinds that are to be met with in Nature. It is of course evident, even on the most superficial survey, that mosses are not all alike, for there are certain broad differences in their general appearance that at once mark some out as quite distinct from others; nevertheless, these external differences would never lead us to suppose that, in Britain alone, more than six hundred kinds have taken up their abode, to say nothing of many others which inhabit foreign countries but do not grow in these islands. Again, it is by no means an uncommon thing to find a plant which, though 
evidently belonging to some one kind or species, yet differs slightly from the ordinary type of that species, though not sufficiently to warrant a distinctive name being given to it; such plants are known as varieties, and these again go to swell the great number of different forms which the moss world includes. Many of the members of this large fraternity are, of course, common enough, as the banks and the woods, the walls and the roofs, in any part of the country will amply testify; others, again, are more fastidious, and must have a habitation just to their liking before they will settle down in life; while some are distinctly rare, and only inhabit a comparatively few favoured localities. There is thus plenty for a moss-hunter to do before he can be said to have exhausted the field of his inquiry; and though, in the case of the beginner, the plants to be gathered on any country ramble will afford plenty of material for study for some time to come, these will afterwards be supplemented from time to time by the more out-of-the-way kinds, which a holiday spent at the English Lakes, or among the Scotch mountains, will enable him to become acquainted with; and the search for these more hidden treasures will add zest to many a woodland stroll or mountain scramble. In what I have to say I shall try, as far as possible, to confine myself for examples to the commoner kinds, as my readers will then be the better able 
to see for themselves what I shall attempt to describe; occasionally, however, I shall be obliged to go somewhat farther afield. Let us now inquire a little more fully as to the

Habitats of Mosses.- "Where should we look for mosses?" is a question that naturally soon suggests itself. "Why, almost everywhere," I should reply; even in the near neighbourhood of the smoky town some few of the more hardy kinds will find a foothold, and these will be some of the last vestiges left behind by the country, as it recedes ever farther and farther away before the all too steady growth of our large cities. But if we would see moss-life in full perfection we must visit the haunts where Nature still holds undisputed sway, and roam among the woods and lanes, the heaths and moorlands, the hills and dales, far from our busy hives of industry.

Although most mosses are very cosmopolitan in their choice of an abode, and may be found in very various localities and positions, yet many have a more or less decided preference for some particular environment, while others, again, are still more closely restricted, either as to the nature of the soil, or the kind of place in which they grow; it is therefore always desirable to note carefully where and under what circumstances and surroundings a specimen has been gathered, as these facts may constitute important aids to its identification. Let us glance at some of the conditions under which 
we should be most likely to meet with the more familiar figures of the moss world, and incidentally we shall obtain an idea of the various forms which these tiny plants assume.

It almost goes without saying that mosses are, as a rule, moisture-loving plants; indeed, we naturally associate them with the trickle of water and with damp, shady places, for amid such surroundings they generally live and flourish as though it were a pleasure to be alive. Thus it is that Woods offer a home to many of the most beautiful kinds, and here we may find them covering the ground with a soft, green carpet, refreshing to the eye, and soft to the tread. And if by chance we light upon some dingle, screened from the blaze of the sun by the leafy canopy of the over-arching trees and shrubs, and where too

the silver brook

From its full laver pours the white cascade, And, babbling low amid the tangled woods, Slips down the moss-grown stones with endless laughter, ${ }^{1}$

not only the ground by the water-side, but the rocks and stones, the dead branches lying about, and the trunks of the trees themselves, will probably be more or less clothed with a delicate green mantle, formed of an almost infinite number of the minute leaves of these diminutive plants; while the nooks and crannies in the banks, which

1 Longfellow. 
are kept constantly moist by the splash of the water or the drip of the rain, will be tenanted by some of the smaller and more dainty species. And again, on looking down into the stream as it runs rippling along we may notice that the rocks and stones which form its very bed are often clothed with a dark green covering of moss, while in the deeper pools long green tresses float gracefully in the water, rising and falling with the current. Plate II. fig. 1 is an enlarged drawing. of a small piece of a particularly pretty little moss, with small, tapering leaves, known as the Dwarf Feather-moss (Eurhynchium pumilum), which generally chooses stony ground and rocks, in shady situations, on which to take up its abode, its small delicate leaves shrinking from exposure to the rays of the sun. Figs. 7 and 19 of the same plate represent small portions of another moss belonging to the same family, the Longbeaked Water Feather-moss (Eurhynchium rusciforme), which is extremely partial to moisture, for it frequently grows, not only on the rocks which are constantly drenched by the spray from some small waterfall, but also on those which are actually covered by the stream, where it seems to revel in the continual flow of the water. These two mosses are members of a large family (the Hypnacea) popularly known as the "Feathermosses," doubtless from the feather-like nature of their growth, though "fern-mosses" would 
almost seem to be a more appropriate designation for them, seeing that their general appearance more frequently reminds one of a fern than of a feather. These Feather-mosses usually grow close to the ground in moist and shady places, and hence it is that in the shelter of the roods we may come across many of them literally running wild, and clothing the soil with their beautiful pale green fronds. The Dotted Thyme Threadmoss (Mnium punctatum, Plate II. fig. 2) is also a familiar inhabitant of the woods, and its large, oval, filmy green leaves easily catch the eye amid the tangle of growth on the bank of path or stream ; it belongs to a specially large-leaved family, some thirteen members of which inhabit these islands. In this particular species, theleaves, when examined with the glass, will be seen to be bordered by a number of long, narrow cells, quite different in form from those which compose the blade of the leaf, which latter are large, and somewhat hexagonal in shape. A magnified drawing of one of these leaves is given at Plate VII. fig. 22.

Among the many other wood-dwellers mention can only be made of two or three. The Wavyleaved Hair-moss (Catharinea undulata) is a somewhat large plant for a moss, with dark green leaves, and is often to be met with in great abundance in woods, or on shady banks by the roadside. Its leaves form very interesting objects for microscopical study, as not only is the cell- 
formation very distinct, and the small grains of the green colouring matter, or chlorophyll, easily seen, but the blade of the leaf is bordered by two or three rows of narrow cells, and the margin bristles with sets of double spines or teeth, a few of which also grow from the back of the blade itself. The beautiful Tamarisk Feather-moss (Thuidium tamariscinum) is perhaps the most fern-like of all the Feather-mosses. Its tiny leaves when seen in profile under the microscope will be found to have a roughened surface, or, in botanical phraseology, to be papillose, a feature which characterises many mosses, and to which I shall have occasion to refer again hereafter. One of the leaves of this moss is drawn at Plate VII. fig. 24, but the scale of magnification is not sufficiently large to show the minute roughness just alluded to. The Broom Fork-moss (Dicranum scoparium) is a frequent denizen of similar localities; it is a robust-looking moss, with bright green leaves, which are all turned in the same direction (secund, as this form of growth is called), and are curved, or sickleshaped. The Wood Feather-moss (Plagiothecium sylvaticum) and the Sharp Flat-leaved Feathermoss (Plagiothecium denticulatum) are woodlovers too, and are common enough in the country; they both have a peculiarly flat growth, a very distinctive feature which is easily recognised again when once observed. The two plants so closely 
resemble one another in general appearance that it is not always easy, especially in the absence of fruit, to distinguish them.

Rocks provide camping-ground for numerous members of the moss tribe, though many of these might also be classed among the moisture-loving plants of which I have just been speaking. Any one who has walked much in a mountainous region will often have noticed some small plant growing in a crack or crevice of the rock, where it would seem that it must have no easy task to obtain a bare subsistence. It is for such a life as this that the tiny rock-growing mosses are peculiarly fitted, for, from their very size, they are able to find a lodgment where a more pretentious plant could not exist; and, being chiefly dependent for their means of livelihood on the air and the rain, they can flourish in situations where larger vegetable growth would be an impossibility. Many of these rock-dwellers, indeed, must be specially adapted to live among dry surroundings, for in the higher mountains, such as those of Wales or Cumberland, we may notice rocks, constantly exposed to the full blaze of the summer sun, which yet bear on their faces patches which, though more like dead seaweed than living plant, will prove, on examination, to be colonies of moss-plants. These particular members of the moss community seem to have the power of sustaining life for a considerable period 
without the aid of moisture, and to be able to revive when the first shower of rain comes to bring the means of subsistence on which they must in the end depend. Plate II. fig. 3 is a diminutive moss known as the Slender Beardless Moss (Weisia tenuis) that may sometimes be met with on sandstone rocks and walls, covering the face with what would appear to the casual observer as a green film of vegetable growth, unless indeed the plants should happen to be in fruit, when the tiny sporevessels will show that there is something of special interest to attract the attention. Under the microscope this little moss forms a beautiful object, with its small strap-shaped leaves, and soft green colouring. Plate II. fig. 8 is another small moss that grows in the cracks and crannies of rocks, usually in fairly high localities.

Walls, whether of stone or brick, are favourite haunts for many of the commoner kinds, as well as for some that are rarer; the cracks and holes in the stones, and in the mortar between the bricks, provide them with a firm anchorage, while the top of the wall, which offers a still more secure vantage-ground, will often be more or less covered with soft, round cushions of moss, formed of small colonies of plants tightly packed together; and these cushions will, at certain seasons of the year, bristle with numerous bright red or yellow stalks, each surmounted by a tiny spore-vessel, the crystal beads of dew or rain, 
which have become entangled among the leaves, glistening brightly in the sun.

It is almost needless to say that no hard-and-fast line can be drawn between the rock-loving mosses, to which I have just referred, and those that I am for convenience classing as wall-dwellers, for in many instances it seems to be quite a matter of indifference whether a habitation shall be sought on wall or rock. The well-known Wall Screw-moss (Tortula muralis, Plate II. fig. 10) is the commonest of our wall-growing mosses. So hardy is it that it will flourish even in the near neighbourhood of a town, and almost any wall, that is not quite too close to the smoke, and that has even the most meagre attractions to offer in the shape of a home, is pretty certain to be inhabited by it. It is easily recognised by the form of its leaves, which are rounded, or obtuse, at the end (spathulate, or spoon-shaped, in botanical language), each leaf being moreover terminated by a delicate, transparent hair, which is really a prolongation of the "midrib or "nerve," as it is called, of the leaf. When a number of these plants grow close together, as is frequently the case, these hair-points give quite a grey or hoary appearance to the green tuft. Plate VII. fig. 25 is a drawing of a leaf on a larger scale. The Grey-cushioned Grimmia (Grimmia pulvinata, Plate II. fig. 13) is another instance of a common wall-growing moss, with hair-points to 
the leaves, and, these being specially long, the hoary appearance of the cushion-like tufts is still more noticeable. At Plate VII. fig. 31 will be found an enlarged drawing of a leaf of one of these plants. The Silvery Thread-moss (Bryum argenteum), one of the lowliest members of the great Thread-moss (or Bryum) family, often grows in great abundance on walls, and, like the Wall Screw-moss above mentioned, will not be deterred even by the close proximity of a large manufacturing town. The plant from which the illustration given at Plate II. fig. 12 was made was gathered from a wall in a suburb of Birmingham, within a comparatively short distance from the centre of the city. This moss is easily recognised by its white, silvery appearance (whence its name), a feature which is due to the delicate and colourless leaves, considerable portions of which, when examined under the microscope, will be seen to be altogether devoid of the green colouring matter or chlorophyll, to which leaves in general owe their green tint.

There are various other members of this same Bryum family that are frequent inhabitants of walls, many of them having much larger leaves, and producing an abundance of pear-shaped sporevessels, which form very conspicuous objects in the spring or early summer, when their warm red colour denotes that they are full of ripe spores. In some parts of the country, as, for instance, in 
the Cotswold villages, the tops of the walls are covered with a thick coating of mud; these mudcapped walls are often tenanted by certain small but specially interesting plants, which seem to prefer this form of abode, more particularly if the district happens to be calcareous in nature, and a careful scrutiny of them will frequently result in a welcome addition being made to the herbarium.

The Hedgerows of our roads and lanes provide shelter for numerous kinds, though many that grow there will naturally also be found in the woods or other shady places. Plate II. fig. 4, the Common Pottia (Pottia truncatula), is a pretty little moss that frequents the banks by the roadside, where in the early spring it may often be seen, with its small, golden-yellow sporevessels, like so many delicate amber cups. The Green-tufted Weisia (Weisia viridula, fig. 9) also grows abundantly in similar situations, and in the spring produces a profusion of fruit; the leaves are long and narrow, and when examined under the microscope it will be found that the margin is slightly rolled or folded inwards (involute, as it is called), a feature which is very characteristic of this particular plant. It is wonderful to think that such a very minute trait, in such a small organism, should nevertheless be so constant as to form a never-failing means of recognition. 
Fallow-fields and bare ground would hardly, one would think, have much to offer to the moss-hunter, and yet in such places some of the specially small and interesting species may be met with. The little moss given at Plate II. fig. 6, the Pointed Earth-moss (Phascum cuspidatum), is an instance in point; it is so small, and grows so close to the earth, that it will pass unobserved unless a close watch is kept for it. The tiny round spore-ressel, with the long, narrow encircling leaves, forms an interesting object under the microscope. A still smaller relative of this moss, the Serrated Earth-moss (Ephemerum serratum), also lives in fallow-fields, and its discovery will well repay a careful search, though from its very small size it is not easily found ; for to the untrained eye, and without the help of a magnifying-glass, a colony of these little plants will only have the appearance of a thin film of green scum. As we shall presently see, it has an especial attraction for the mossstudent, owing to the fact that it affords a very good illustration of the first stage of moss-growth. The Common Pottia (Pottia truncatula), before described, is also a constant dweller on the bare ground of unsown fields, and many other mosses could be named that frequent similar localities.

Heaths and Commons are the abodes of some of the more hardy kinds, which are not dependent for their well-being on a moist atmosphere, but 
seem rather to prefer the bracing air of more exposed situations. Plate II. fig. 14, the Dwarf Swan-neck Moss (Campylopus pyriformis), is one of a family which owe their common name to the fact that the fruit-stalk, when moist, is considerably bent, and is strongly suggestive of the arching of a swan's neck; it is almost certain to be found on any moorland, where also some of the Hair-mosses (Polytrichum) will as surely be growing. These Hair-mosses are among the most robust of all the tribe, and often attain to a considerable size; any one who has noticed with some attention the ordinary growth on a wild open heath will remember a dark green and rather coarse kind of moss, with stiff, narrow, somewhat bristle-like leaves, giving to the tuft, when of any size, the appearance of a collection of so many small bottle-brushes. The Purple Fork-moss (Ceratodon purpureus), one of the most cosmopolitan of our mosses, grows most plentifully on peaty and sandy ground; and in April and May many a stretch of moorland becomes tinged with red, owing to the presence of innumerable spore-vessels of this prolific moss, each on its own bright crimson stalk. The Common Cord-moss (Funaria hygrometrica, Plate II. fig. 18) is also partial to similar positions, and especially to cinder-heaps, and to soil that has been burned. It is easily known by its large and somewhat filmy leaves, which grow in a bud-like 
cluster close to the ground, as also by its conspicuous, pear-shaped spore-vessel, formed at the end of a long, flexible stalk, which is frequently much curved; this spore-vessel, when ripe, forms a particularly beautiful object under the microscope.

Marshes and Bogs must always have an attraction for the moss-hunter, for here he may meet with some of the most beautiful of our species, such, for instance, as the exquisite Bog-mosses (Sphagna), those pale green, wet, spongy plants that are so familiar to frequenters of our Scotch and Welsh mountains. No words can do adequate justice to the extreme beauty of these Bog-mosses, as seen against a black background under the microscope, when, owing to the delicate structure of the leaves, and the practical absence of colour, they have all the appearance of being formed of some silvery-white material of almost unimaginable fineness. The cell-formation of the Sphagnum leaf is exceptionally large and open, thus enabling the plant to retain a considerable amount of water, to which fact it owes its spongy character. Plate VII. fig. 41 is a drawing of a small piece of a leaf of the Blunt-leaved Bog-moss (Sphagnum cymbifolium), one of the commonest of the family ; this is magnified 140 times, and thus shows very clearly the large, peculiarly shaped cells to which I have referred. The Pointed Bog Feathermoss (Hypnum cuspidatum) is also common in these moist regions; its glossy leaves are pale 
yellowish-green in colour, and those at the extreme tips of the stem and branches closely overlap one another, thus forming a somewhat bud-like point, which constitutes a very characteristic feature of the plant. The Fountain Apple-moss (Philonotis fontana), with its bright crimson stem, and light green foliage, seems to prefer the wettest of wet places, and on the margins of a mountain stream, or close to the place where a spring bubbles up on the hillside, we may often see it in great abundance.

Trunks of trees not unfrequently afford quarters for some very interesting plants, and a good deal of moss-lore may be picked up from them by the use of an ordinary hand magnifying-glass. In such positions, for instance, may be seen many of the members of the Bristle-moss family (Orthotrichum), the spore-vessels of which-sometimes nearly buried in the surrounding dark green leaves, and in other cases rising above them-offer, as we shall have occasion to note hereafter, several specially noteworthy features. The Bent-leaved Weisia (Dicranoweisia cirrata), which generally grows in compact, cushion-like masses, and often, in the winter, produces abundance of fruit, and the Green-tufted Yoke-moss (Zygodon viridissimus), which also forms closely packed tufts of pale green plants, are two further instances of tree-growing mosses.

Thatched roofs, when a friendly ladder is at 
hand, will often furnish many specimens for the collector, such as the Great Hairy Screw-moss (Tortula ruralis), a near relative of the Common Wall Screw-moss (Tortula muralis); certain forms of the Cypress-leaved Feather-moss (Hypnum cupressiforme), one of the commonest of our Feather-mosses; and the Bent-leaved Didymodon (Didymodon flexifolius), so called because its leaves are somewhat bent back (squarrose), as will be seen on reference to Plate VII. fig. 33 where a magnified drawing of one is given.

Not only do we find that, roughly speaking, certain mosses have a natural predilection for a special form of habitation, but further, that some are attracted by the geological character of some particular locality. Thus, many most interesting kinds abound in limestone districts, such as Dove Dale and Miller's Dale, in Derbyshire, for which we should search in vain in a non-calcareous region. Plate II. fig. 15 is a drawing of a small yellowish-green moss, the Curly-leaved Screwmoss (Trichostomum tortuosum), which is comparatively seldom met with except on limestone rocks; it has long fragile leaves, which, when dry, are strongly twisted or contorted-to which fact, no doubt, it owes its specific name. An enlarged drawing of one of these leaves, showing its peculiarly wavy margin, is given at Plate VII. fig. 32. The Crisped Neckera (Neckera crispa), with its delicate undulated leaves and 
its flat growth; the Eder's Apple-moss (Bartramia (Ederi), with its small, round, apple-like spore-vessel; the Tall Anomodon (Anomodon viticulosus); and the Star-leaved Thyme Threadmoss (Mnium stellare), are all instances, among many that could be quoted, of mosses that have a distinct preference for calcareous districts. On the other hand, the plant given at Plate II. fig. 5, the Yew-leaved Flat Fork-moss (Fissidens taxifolius), is equally partial to a heavy soil, such as marl or clay. This moss is a member of a small family, represented by some fifteen British individuals, all of which have a very strong family resemblance, and are, from their peculiar mode of growth, always easily known. It will be seen from the drawing that the plant has a markedly flat appearance, all the leaves being arranged on the stem on the same plane. And on looking closer still it will be found that each leaf-blade (lamina) is, for about a quarter of its surface, double, as though a tiny flange had been fastened to the mid-rib or nerve, the stem itself passing between these two leafy surfaces. This is more clearly shown at fig. 19 of Plate VII., which represents a leaf drawn to a larger scale. The shaded portions in this and the previous drawing indicate these double parts, the increased thickness rendering them somewhat more opaque. The Pointed-leaved Weisia (Weisia mucronata, Plate II. fig. 16), with its tapering and pointed 
leaves, and the Pale-leaved Thread-moss (Bryum pallens, fig. 17), with its bright crimson stem and somewhat large leaves, which are frequently tinted with the same bright colour, are further instances of clay-dwellers.

As a rule mosses do not like the sea, though here, as usual, Nature draws no hard-and-fast line, for some few may be occasionally met with growing comparatively close to the shore, and even on the sandhills flanking it. For instance, the Seaside Sessile Grimmia (Grimmia maritima, Plate II. fig. 11) is a very beautiful little moss that makes its home on rocks close to the sea. I gathered the plant from which my drawing was made in the splash of a small stream which trickles down the face of the rocks in one of the coves at Wooda Bay, in Devonshire, and here it was flourishing within a comparatively few yards of high-water mark, doubtless exposed to the spray as the waves break upon the cliffs.

It must not be supposed that the above slight sketch forms by any means an exhaustive enumeration of the homes of these plants; for, like the grass, the mosses may well say, "Lo! I come creeping, creeping everywhere." I have only attempted to give a rough idea of the positions or localities in which we may generally expect to find the tribe more or less plentifully represented. With the rarer species local considerations, such as the geological formation 


\section{MOSSES AND LIVERWORTS}

of the rocks, their altitude above sea-level, and other similar matters, have an important bearing, and' details such as these must be learned either from books, or, better still, from the experience which time and a close companionship with Nature will alone bring.

Seasons for Gathering.-As it is well to be conversant with the kind of place to which our search for treasure should be directed, so the further question, "When should we look for mosses?" is not without its importance. To this I should be inclined to answer, "Always; at any time"; for it is not the least among the many attractions that this particular study offers, that there is no "close time" for mosses, and even when the trees have been stripped of their leaves by the winter's frosts and winds, and the snow lies thickly upon the ground, the small green cushions on roof and wall-bristling perhaps with pale yellow stalks which betoken the coming fruit, or studded with the pretty cup-like heads of the newly formed spore-vessels-show that there is plenty abroad to interest a moss-student, and serve to remind us of the time when the woods will be green again, and the glory of the summertime will be with us once more.

But though to a lover of mosses a walk in the country at any season can never be without interest, yet there are certain times of the year that have a peculiar attraction for him, for it is when they are 
in fruit that mosses are most easily recognised, and then too it is that they afford specially fascinating material for microscopical examination. Though some of our British mosses have never been known to fruit here, and though in not a few kinds the fruit is comparatively rarely formed, yet in the large majority the spore-vessels are matured every year, and with each particular species at about the same time. The greater number reach this stage either in the spring or early summer, or in the late autumn or winter, and consequently these seasons are most favourable for the moss-hunter's work. Mosses being, as a rule, moisture-loving plants, the hot, dry summer days are naturally least conducive to their growth, though some select even that time of year for fruiting. Thus it is that all the year round the moss world has its attractions for him who has the eyes to see the beauties that it contains, and month by month it will yield material in abundance, which may provide an incentive for a country ramble, as well as endless pleasurable occupation for leisure hours.

\section{LIFE-HISTORY}

The story of the growth of a moss from its earliest start in life-as represented by the spore - to the time when it has developed its fruit, and may be deemed to have arrived at its most 
perfect form, is full of interest and wonder, even when such a story is briefly told on paper; but the interest and wonder are increased a hundredfold, if the various steps in this lifehistory are followed out through an actual acquaintance with the plants themselves, as may, to no inconsiderable extent, be done with the help of a comparatively inexpensive microscope, or even by means of a good hand magnifyingglass. I hope, therefore, that the following sketch of the development of a moss from infancy, through youth and maturity to old age, may serve to induce some of my readers to see for themselves what I now propose to try to explain. Let us begin our story with what will form a very convenient starting-point, namely,

The Spore, a tiny speck of vegetable life from which our future moss-plant, with all its wonderful mechanism, will take its rise. These mossspores vary somewhat in the different species, both as to size (often an important factor in the diagnosis of a specimen), and form, though they are usually round. In every case, however, a single one is so minute as to be practically invisible to the naked eye, and it is therefore only when present in large numbers that the spores can be seen without the aid of a glass; and even then they only appear as a delicate film of coloured dust, or, should they happen to be just making their escape from the spore-vessel, as a 
slight puff of smoke. Plate III. fig. 1 represents a collection of spores, and some idea may be obtained of their extreme minuteness from the fact, that, as thus drawn, they are fifty-one times larger than the originals.

While speaking of the spore a few words may be added as to the broad general distinction between the two divisions which botanists make of the members of the vegetable kingdom-namely, the so-called "flowerless plants" (cryptogams) on the one hand, to which the mosses and liverworts, among many others, belong; and what are popularly known as "flowering plants" (phanerogams), such as the common plants of our meadows and gardens, on the other. In the former case fresh individuals are produced from spores (each of which consists of a single cell), while the latter spring from seeds, which are multicellular, or built up of many separate cells.

Each individual spore is provided with two extremely delicate coverings or membranes, an outer and an inner one; and when we consider the actual size of these tiny specks it is almost impossible to believe that there can be so much detail in such a very restricted space, so true is it that the infinitely small in Nature is quite as wonderful in its way as the infinitely great.

Let us suppose that one of these spores has fallen to the ground under conditions favourable to its growth; what takes place? Well, in a short 
time it begins to swell, and presently the inner of the two coats or membranes bursts through the outer one in the form of a very fine threadlike growth, which grows and branches in various directions, often, and especially if moisture is present, increasing with considerable rapidity.

This first growth from the moss-spore is known as the Protonema of the moss. Tangled masses of these delicate threads, looking like soft green velvet, may frequently be seen on the surface of the earth in moist situations-as, for instance, on the soil in the flower-pots of a greenhouse, or in the nooks and corners in the banks of a stream. When examined with a good glass, or under the microscope, they will be found to consist of a succession of long, narrow cells, as shown in fig. 2 of Plate III., where I have drawn, on a somewhat large scale, a very small portion of one which was developed from a spore of that very tiny moss, the Serrated Earth-moss (Ephemerum serratum), which, as I have already stated, grows in fallow-fields, and in similarly exposed positions, and is so minute that nothing but a close and careful scrutiny of the ground will avail to discover it. It is especially interesting to the bryologist from the fact that, whereas in most mosses the thread-like growth dies away at an early period in the plant's history, in this one, as also in a few others, it frequently has a much longer existence, and consequently provides us 
with a specially good illustration of this stage of moss-life. While, as a rule, this first growth from the spore assumes this branching, threadlike form, in some few cases, as for instance in the Bog-mosses (Sphagna), it is represented by a flat green plate or frond, which, as we shall hereafter see, closely resembles the early stages of many of the liverworts.

After a time small bud-like bodies make their appearance at certain points on these green threads, as also shown at Plate III. fig. 2; these are the beginnings of future moss-plants, for each of them, as it increases in size, will send down tiny rootlets to anchor the plant, and stem and leaves will gradually make their way up into the light and air, and thus eventually the full-grown mossplant will be developed. Any one may easily see for himself these early days of a moss's career, by scattering some spores from a ripe spore-vessel on a bit of broken flower-pot; this should be placed upon a piece of flannel, the whole being then covered by a bell-glass. If the flannel is kept constantly moist, in course of time-sometimes many weeks after sowing-a thin green film will make its appearance on the crock, and soon after a plentiful crop of the green threads will follow. I have tried this experiment with the spores of the beautiful Swan-neck Thyme Thread-moss (Mnium hornum)-which should be sown in May-and after much waiting have been rewarded 
by the growth of a delicate little plant with tiny green leaves, scarcely more than the tenth of an inch high, and bearing only a distant resemblance to the form that it will eventually take.

The next step in our story brings us to the flowering part, or Inflorescence; for though mosses are commonly known as "flowerless plants," this is really only the popular way of saying that they cannot boast of anything which, in outside appearance, corresponds with the brilliantly coloured parts of the familiar plants of our hedgerows and gardens, which we designate by the word "flowers." A botanist, however, looks at the matter from a different point of view, and to him a flower may generally be said to be the part of the plant which contains the reproductive organs-the bodies, that is, to which is specially assigned the duty of providing for the production of fresh individuals. Thus, in the case of most ordinary flowers, coloured flowerleaves, or petals, enclose the stamens and seedvessels, which constitute the reproductive organs, and by means of which ripe seeds may be formed. Using the word in this wider sense, mosses are, as we shall see, entitled to rank as flowerproducing plants.

On examining various pieces of moss with a glass, a number of tiny bud-like growths will often be noticeable; these become all the more prominent when seen in the microscope, more 
especially in such plants as the Feather-mosses, where, as the leaves do not grow very close together, they are not liable to be covered over, as in many other cases. These are the so-called "flowers" of the moss, the name having doubtless been suggested by the fact that they contain the reproductive organs. But in external appearance they have nothing whatever in common with a "flower," as that word is popularly understood.

These moss-flowers will always be found in one or other of two positions on the plant, namely, either at the end of the stem, or of a branch from it, or on the side of the stem. In the former case the flower is said to be "terminal"; Plate III. fig. 4 is an illustration of this, taken from the Pink-fruited Thread-moss (Webera carnea), a plant which is partial to the moist banks of ditches and streams, and which turns a warm red when old. Here, it will be observed, there is a very decided swelling at the tip of the stem, giving the bud-like appearance to which I have alluded. Sometimes this terminal flower takes the form of a tiny rosette of leaves, a feature which, when once seen, is easily recognised again.

We have only to examine the ground on any heath or common in the spring to find this fact plentifully illustrated, for there some form of the sturdy little Hair-moss (Polytrichum) family, referred to on page 20 , is sure to be 
growing; and as these rosette-like flowers in the members of this particular group are often brightly coloured, they are all the more conspicuous. I well remember spending an early spring holiday, at the end of a specially wet season, on the borders of the New Forest; the constant rain had called forth the mosses in full perfection, and in one particular stretch of heathy land the ground in places was thickly carpeted with tufts of some of the smaller kinds of Hair-moss, which were covered with these tiny rosette-like flowers, some of them still quite young and of a pale greenish yellow, others more advanced and of a warm orange colour, while others, that were still more fully developed, showed up against the dark green bristle-like leaves in various shades of red and crimson. The sight was one not easily to be forgotten, especially by any one who could read the hidden meaning of these numberless small round heads of colour on the sombre tufts of moss.

In figs. 3 and 5 of Plate III. these bud-like growths have been formed in the second of the two positions above referred to, namely, on the side of the stem, nestling among the leaves. Here the flower grows in the angle formed by a leaf with the stem, or, in botanical language, in the axil of a leaf; hence it is said to be axillary. Fig. 3 of the same plate is a drawing of the Common Flat Fork-moss (Fissidens bryoides), 
another member of that interesting little group of plants of which mention has already been made (p. 24) as being distinguished by their specially flat growth, and by the curious double thickness of a portion of the leaf. In this particular plant one of the features by which it is recognised is the presence of these tiny flowers in the axils of many of the leaves, as shown in my drawing. Fig. 5 represents a small piece of one of the commonest of our Feather-mosses, the Prolonged Feather-moss (Eurhynchium pralongum), which grows creeping on the soil, or on tree-stumps in the shade of the hedgerow, and in other like situations, often sending out long, pale green, feathery fronds, which make their way into the cracks and crannies where they can get screened from the sunlight, clinging so tenaciously to the ground, by means of their tiny rootlets, that it is difficult to disentangle a perfect specimen. In this case three flowers are shown, each under cover of a leaf.

Now let us, with the help of a dissecting-glass and a pair of dissecting-needles, carefully cut away the leaves from some of these bud-like bodies. In the great majority of cases we shall be struck by the fact that these leaves are larger, and often much larger than the ordinary leaves of the plant, and, moreover, that they differ very considerably from them in form. How great this difference may be, will be readily understood by 
a comparison of figs. 15 and 16 of Plate IV. with fig. 17 of the same plate, the former representing some of the leaves taken from the stem and branches of the Common Rough-stalked Feathermoss (Brachythecium rutabulum) - frequently to be met with in the country, growing in bright, glossy green patches on banks, walls, trees, etc.while the latter gives one of the leaves of which the flower is formed. In some cases, however, the variation in form between the two kinds of leaf is very slight, as shown in figs. 18 and 19 of Plate IV., which give leaves (the former one of the ordinary leaves of the plant, the latter one from a flower) belonging to a very common moss (Camptothecium sericeum), the pale yellow, silky sprays of which often form conspicuous objects on walls, roots of trees, and banks by the roadside.

These large leaves doubtless serve a very real purpose in the life of the plant, as they must help to retain small drops of rain or dew round the reproductive organs enclosed in them, and thereby aid, as we shall presently see, in the fertilisation of the latter.

After removing several layers of these leaves, we shall come upon a quantity of loose cellular substance, which, when examined with a fairly strong lens in the microscope, is seen to consist of numerous very small bodies of a peculiar form; these are the Organs of Reproduction. There 
are two kinds, namely, (1) the fertilising organ (antheridium), and (2) the fruit-bearing organ (archegonium). Let us make a closer acquaintance with each, taking first

The Fertilising Organ (antheridium), the function of which is to provide that wonderful fertilising matter, by the aid of which the fruit is formed, and in the absence of which no fruit is ever produced. Plate III. fig. 7 is a highly magnified drawing of a group of these bodies, taken from the Common Hair-moss (Polytrichum commune), a denizen, as we have already learned, of our heaths and commons. They are almost always somewhat sausage- or cucumber-shaped, as in my illustration, and are accompanied by numerous very delicate threadlike bodies known as paraphyses, which sometimes, as in this instance, are swollen or thickened at the end, giving them a distinctly club-like form.

Botanists were for long puzzled as to what use these delicate threads could be to the plant, for their constant presence seemed to imply that they served some useful purpose, Nature not being given to wasting her energies in the production of parts to which no function is allotted. It is now believed that at least one duty which they perform is to help to retain moisture round the reproductive organs, a very important matter, owing to the fact that, without the presence of water, fertilisation cannot take place. 
The Fruit-bearing Organ (archegonium)-to which is entrusted the duty of producing the fruit of the moss-is very different in appearance from the fertilising organ, as will be seen by a reference to Plate III. fig. 6, which represents two taken from the Velvet Feather-moss (Brachythecium velutinum), another frequent inhabitant of our country hedgerows. It is somewhat flaskshaped, having a long, slender neck, ending in a round, swollen base, the whole resembling in outline a diminutive flask or bottle. In colour it is a deep crimson, and again the microscope generally discloses the presence round it of a number of the thread-like paraphyses. As the organ ripens, an extremely fine passage is formed down the centre of the slender neck, by the parting of certain of the cells. The cells, too, at the top of the neck roll back, thus opening the way into this passage, which leads directly into a cavity in the swollen base. Here there is one special cell, known as the oosphere, from which, in due course, the fruit will spring, and to which I shall refer again very shortly.

It is perhaps well that I should point out in passing the extreme minuteness of these reproductive organs; many of them, even when carefully mounted, are not more than just visible to the unaided eye, and large numbers may be packed in one of the small bud-like flowers, which is itself hardly noticeable, even on a more or 
less close inspection, unless with the help of a glass. The fact that those given at fig. 7 of Plate III. are thirty-one times, and those at fig. 6 fifty-one times, larger than the originals, will afford some idea of the microscopic size of these bodies. It will easily be believed that in order to examine such minute organisms properly it is necessary to have recourse to the help of a microscope, though, with a good magnifyingglass, such as one of the platyscopic lenses mentioned at page 151, they may be distinctly seen, after their leafy coverings have been removed.

While, in the majority of mosses, the reproductive organs are formed inside bud-like flowers, as already described, this is not always so, for sometimes they grow singly, or in clusters of very few, in the axils of the ordinary leaves, or in other positions, and in such cases are, of course, not so easily found. Indeed, to meet with them is then frequently a task calling for the exercise of considerable care and patience; and, needless to add, the help of a good glass and dissecting-needles is a necessity.

Fertilisation.-When the fertilising organ is ripe it bursts at its upper end, and discharges a cloud of very minute cells, inside each one of which is a still more minute spiral thread-like body (antherozoid); this is the wonderful fertilising medium to which reference has already been 
made, by the help of which the fruit is eventually formed. These spiral bodies are so diminutive that they only become visible at all when highly magnified; they have this wonderful faculty, that when they are freed from the surrounding cell-walls by which they are at first enclosedand this takes place soon after their escapethey are able to move about in water, by the help of two very delicate hairs, or cilia; indeed, when seen for the first time under the microscope they might easily be mistaken for microscopic animals, so decided is their motion. We can now understand how it is that water plays so important a part in this matter of fertilisation, for by its means one of these tiny spiral bodies can find its way to the head of one of the ripe fruitbearing organs; it can then pass down the narrow passage which, as we have seen, has been formed down the neck, and so enter the cavity in the swollen base, and it will there fertilise that special cell to which I have alluded above. Sometimes we may be so fortunate as to examine a specimen under the microscope just when the fertilising organs are ready to burst, and a slight pressure on the thin cover-glass will then suffice to bring this about, and we may see the cloud of cells escape under our very eyes. Plate III. fig. 9 is a drawing of a group of the reproductive organs of one of the Thread-mosses (Bryum intermedium), and shows one of the cucumber- 
shaped fertilising organs discharging its contents. The rosette-like flowers of the Hair-moss (Polytrichum) family, already described at page 34, will provide convenient illustrations of the same thing; they should be examined in early summer, and, of course, fresh specimens must be used.

There is one feature in connection with these reproductive organs that calls for special mention, as it often constitutes a very important item in the diagnosis of any particular species; this is the relative positions of the two kinds on the plant. In some instances the fertilising organs alone are formed on one plant, and the fruitbearing organs on an entirely separate one-in which case the moss is said to be dioicous; in others they both grow on the same plant, but separated the one from the other, and the moss is then spoken of as autoicous (or monoicous). Again, sometimes the two kinds are not only borne on the same plant, but are actually mixed together, and the moss is then known as synoicous; while if both fertilising and fruit-bearing organs are to be found in the same flower, but in distinct groups, as occasionally happens, we have a paroicous moss. Plate II. figs. 4 (Pottia truncatula), 5 (Fissidens taxifolius), 10 (Tortula muralis), and 13 (Grimmia pulvinata) are instances of autoicous plants, while those given at figs. 1 (Eurhynchium pumilum), 2 (Mnium punctatum), 12 
(Bryum argenteum), and 17 (Bryum pallens) are dioicous. At Plate III. fig. 8, moreover, we have an example of a synoicous group. This represents some of the reproductive organs of the Small-mouthed Thread-moss (Bryum inclinatum). It will be observed that the two kinds are intermingled, accompanied, as usual, by a number of the thread-like paraphyses.

It is impossible, I think, to contemplate this mysterious act of fertilisation without feelings of wonder, almost amounting to awe. That a living thing of any kind should originate from the union of two microscopic cells, is, of itself, marvellous enough. But when we know that that living organism will not only belong to one particular tribe of plants, but that it will reproduce the special form of the parent plant, and will, moreover, repeat all the minutest details of the latter, down to the shape and size of the cells, and even the thickness of the cell-walls, the marvel is increased beyond expression.

But here we have come to one of the limits to our knowledge, for we know no more what fertilisation really is, how it is that so much is brought about by the simple union of these two cells, than we know what life itself is, and how it originated. We can only note the altered conditions that result from varied circumstances. And this we do know, that when the fertilising body has found its way to the base of the fruit- 
bearing organ, and not until then, a change takes place in the latter. Instead of shrivelling up and dying, as it otherwise most assuredly would do, its swollen base becomes more and more swollen, owing to the growth inside of the young spore-vessel, which has arisen from the special fertilised cell (oosphere), and which is constantly increasing in size, and ever tending to force its way upwards towards the light. The pressure which it thus exerts on the delicate walls of its tiny prison at length becomes so great, that it bursts through them, and rises up on a stalk (seta) of its own, and generally bearing on its end the upper portion of the fruit-bearing organ inside which it was formed, which thus makes a kind of covering for the young spore-vessel, and is known as the reil or calyptra. The lower portion, left behind, is the sheath, or vaginula.

Fig. 10 of Plate III., taken from the Common Wall Screw-moss (Tortula muralis), to which reference has already been made, affords a good illustration of this, for on the end of the pale yellow fruit-stalk will be seen the veil, looking like a tiny extinguisher; and under a low power in the microscope we may get a glimpse, through its thin, transparent walls, of the young, halfformed spore-vessel inside, which, in this instance, is in a very early stage of its development, and is as yet hardly recognisable as a spore-vessel at all. Towards the close of winter, or in the very 
early days of spring, the small round cushions of this moss, on the tops of the walls, bristle all over with tiny pale yellow stalks, among which the rain-drops sparkle in the sunlight like so many diamonds; these bristling cushions will provide numerous examples of what I have just described, and an ordinary hand magnifying-glass will suffice to show that nearly every little stalk is terminated by one of these veils. At fig. 11 of the same plate we have a veil detached from its fruit-stalk, the small point at the top being the shrivelled-up end of the fruit-bearing organ, of which it once formed the upper part. The veil (calyptra) drawn at Plate IV.a, fig. 1 , is a still more notable instance of the same type. Well may the members of this particular family be known as the "Extinguisher-mosses." In this instance, too, the young spore-vessel is much more advanced, and closely resembles the appearance that it ultimately assumes.

The veil does not always take this extinguisher form; for instance, at Plate III. fig. 12 we have one that is wider, and is, moreover, covered with numerous long hairs, which give it quite the appearance of a fur cap; this veil is taken from the Aloe-leaved Hair-moss (Polytrichum aloides), another frequent inhabitant of our heaths and commons. Again, fig. 14 of the same plate shows an entirely different kind of veil; this is said to be mitre-shaped (mitriform), because of a resem- 
blance which it is supposed to bear to a bishop's mitre; its sides are marked by a number of grooves, running from one end to the other, and are also clothed with numerous short hairs. This is the veil of the River Bristle-moss (Orthotrichum rivulare), a very dark green, almost black moss, which loves to grow on rocks and tree-roots near to water, and which may even be seen with its very long branches floating in the stream.

There is one point in connection with the veil (calyptra) to which a few words of passing reference should be made, illustrating, as it does, the marvellous regularity that we find everywhere ruling in Nature, even down to the most minute details. When the upper portion of the fruitbearing organ bursts away, as above described, owing to the increasing size of the young sporevessel, thus forming the veil, this bursting may take place in one of several ways. For example, it may happen that the lower edge of the veil is, so to speak, clean cut, as in Plate III. fig. 11, or the tearing away may have left the margin jagged and irregular; or again, the veil itself may have a certain number of splits or cracks running up its sides, as though it had been strained beyond its utmost stretching-point. The interesting feature in the matter is, however, this, that whatever the particular manner of bursting, it is practically always the same in the same species, and thus not unfrequently this seemingly 
trivial detail may act as a clue to the correct naming of some particular plant: an illustration of the fact which is constantly impressed upon us in the study of any branch of natural-history -and which applies with special force to the moss world - that no point, however small, is too trivial to be taken account of.

The Capsule.-As the young spore-ressel increases in size it gradually pushes off the veil, and thus eventually we arrive at the fully developed spore-vessel, or capsule, the fruit of the moss. In its earlier days the capsule is generally green in colour, but as it ripens its hue changes to warm yellow, brown, or crimson, and in its mature stage it forms a very beautiful object for microscopical examination, under a low-power lens, and with a black background illumination. Moreover, as we shall soon see, from the point of view of its structure, and of the marvellous adaptation of its various parts to the ends which they are formed to serve, the interest of our story culminates with the capsule.

As may be supposed, the capsule varies greatly, both in form and size, in the various species; with the help of Plates III., IV., IV.a, and IV.b, let us take a glance at some of its most characteristic aspects. Plate III. fig. 15 gives the long, narrow capsule of our old friend the Wall Screw-moss (Tortula muralis), that constant denizen of walls, both brick and stone, and Plate IV.a, fig. 10, 
shows, on a somewhat larger scale, the similar capsule of another member of the same family, the Wide-leaved Screw-moss (Tortula lavipila). In both cases the form is said to be cylindrical, that is, like a small cylinder. Plate III. fig. 19 is an instance of the same thing, though in this case the capsule is not so long; it represents the capsule of the Purple Fork-moss (Ceratodon purpureus), to which reference has been made on page 20 , as one of the most widely distributed of all our mosses. This capsule is specially interesting from more than one point of view, as we shall have occasion to see. Fig. 16 of Plate III. is a very representative example; this is the capsule of the Velvet Feather-moss (Brachythecium velutinum), which is so common in country lanes, growing on the hedge banks, and on the roots of trees, etc.; it is egg-shaped (ovate) in form, and assumes a somewhat drooping or bent attitude on the fruit-stalk, a feature which, in a greater or less degree, characterises the capsules of many mosses, and is an important item in their diagnosis. Such capsules are said to be cernuous. A reference to Plate IV.a will show some of the more familiar variations in this matter of the position of the capsule as regards the fruit-stalk. Thus the capsule given in fig. 9 is erect; in fig. 6 it assumes a horizontal position; in fig. 7 the bend in the stalk is very pronounced; while in fig. 8 the capsule droops so much that 
it hangs with its mouth directed to the ground (pendulous, as this position is called). At fig. 17 of Plate III. we have a much more rounded or spherical capsule; it is taken from the Common Apple-moss (Bartramia pomiformis), a beautiful little pale green moss, which is particularly partial to dry, shady banks, where the soil is of a sandy nature. Under such conditions it often spreads and flourishes, and the groups of small round capsules-which in the spring, when newly formed, are light green in colour, and later on turn a warm brown-form very conspicuous objects. This particular capsule, moreover, is specially long-lived, and it is by no means unusual to find the vivid green heads of the young fruit growing side by side with the empty brown shells of those which were produced in the previous year. The name "Apple-moss," given to the members of this family, would seem to have been suggested by the evident resemblance which the capsule bears to an extremely diminutive apple. Fig. 11 of Plate IV.a shows this capsule on a larger scale.

The capsule drawn at fig. 18 of Plate III. is again rather long in proportion to its width, and is moreover distinctly bent, or inclined; it belongs to the Wavy-leaved Hair-moss (Catharinea undulata), mention of which has also been made in an earlier page (see page 12). The fresh green capsules of this moss, often still covered by the 
long, slender veil, are familiar objects in the autumn, growing in the shade of a roadside which is overhung by trees, or in the depths of the woods; and in the early spring these same capsules, which will then have turned a deep brown, may be seen, either packed with spores, or like so many delicate empty urns. Fig. 20 of the same plate is another instance of a similar form; it is the capsule of the Marsh Fork-moss (Dicranum palustre), which, as its name implies, inhabits marshes and other moist situations.

At fig. 21 of Plate III. is a capsule which is characteristic of the larger forms, such as those which are met with in the Bryum and Mnium families. It belongs to the moss known as the Swan-neck Thyme Thread-moss (Mnium hornum), a name undoubtedly suggested by the peculiar bend of the fruit-stalk. This moss grows in the greatest profusion in the shady recesses of the woods, often carpeting the banks and the roots of the trees with a thick covering, the bright golden green of which is then especially refreshing to the eye. It is then, too, that the plant forms its fruit, which is constantly produced in great abundance, the beautiful golden-brown capsules, each at the end of a gracefully curving stalk, making a striking contrast to the sea of green from which they rise; indeed, common as this capsule is, it always rivets the attention, not only on account of its size, but also by reason 
of its form and colour. When seen under a low-power lens in the microscope, emptied of its spores, and with the beautiful fringe of teeth all round the mouth expanded to the utmost, it forms an object the beauty and fascination of which it would be difficult, indeed, to over-estimate. Fig. 9 of Plate IV.b is a drawing of the capsule in this condition. At fig. 23 of Plate III. we have the capsule of the Common Pottia (Pottia truncatula), an inhabitant of roadside banks and fallow fields; its pretty little cup-shaped capsules are produced in considerable quantities in the late autumn and early spring, and the whole plant in this stage makes a very interesting subject for a microscopic slide. The tiny globe-like capsules given in figs. 24 and 25 belong to the Pointed Earth-moss (Phascum cuspidatum), which also lives on shady banks and in fields, though a very close inspection of the ground is necessary if these diminutive round globes, enveloped in their surrounding leaves, are not to pass unobserved. When the capsule is ripe it turns a warm red colour.

Plate IV. fig. 1 is a drawing of a capsule of another of our very small mosses, the Fallow-field Cord-moss (Funaria fascicularis), which, as its name implies, is found-though not in such abundance as the plants just referred to-in fallow-fields, especially on a clay soil; it also is so small that the ordinary observer would pass 
it by unnoticed, though the more practised eye of the moss-hunter would doubtless be attracted by the minute green growth, showing itself here and there where some slight hollow retains the moisture longer than in the more exposed parts of the field. In this case the capsule is pearshaped (pyriform). I have given the capsule figured at Plate IV.a, fig. 14, on account of its very unusual form; indeed, there is something quite elfish in the appearance of the plant from which it is taken (Buxbaumia aphylla, or the Leafless Buxbaumia), for it consists of little else than this strange-looking capsule, the leaves being reduced to a few scale-like growths. One is not surprised that, in former days, before its true nature had been ascertained, it was thought to be some form of fungoid growth. It is far from being a common plant, and, indeed, is distinctly rare, though it may sometimes be found on the ground, or on rotten wood, generally preferring the shade of a fir wood. It has a very peculiar way of suddenly disappearing, and will seldom revisit old haunts.

The above instances will serve to show some of the more general shapes which the capsule takes, though many slight variations occur in the various species, all of which are important as helps to identification. Let me add a few illustrations of such variations. At Plate IV. fig. 2 is a representation of the capsule of the 
Purple Fork-moss (Ceratodon purpureus), a moss which we have already met with several times. At its lower end, or neck, as it is called, a small swelling in the capsule wall will be seen. Such a capsule is said to be strumose, a word derived from the Latin struma, a wen. A minute detail like this might seem, at first sight, to be scarcely worth observing, or may even pass unnoticed, and yet in this particular plant this slight swelling is always present, in a more or less marked degree, and is one of the signs by which it is known. With a good lens the swelling may easily be seen, even in the field. In some cases the part of the fruit-stalk just under the capsule becomes very much swollen (forming what is known as an apophysis), as illustrated by figs. 12 and 13 of Plate IV.a. It will readily be believed that such a striking characteristic is of importance as regards identification. And lastly, contrast this form with that of the capsule at fig. 15 of the same plate (Webera elongata), where the neck of the capsule tapers very gradually into the fruit-stalk, giving a long, drawn-out appearance to the whole.

Now notice the oblique mouth of the capsule of the Common Cord-moss (Funaria hygrometrica), drawn at fig. 3 of Plate IV., a moss frequently to be found growing on heaths, banks, and walls. This same capsule is also given at Plate IV.b, fig. 1 , in order to illustrate another feature, 
namely, the difference often to be observed in the external appearance of the capsule wall, in its dry condition, as contrasted with it when moist. My drawing was made from a dry capsule, and shows the irregular furrows and ridges which appear in it when in that state, though under the influence of moisture no trace of them will be seen. Then look at fig. 13 of Plate IV., the capsule of the River Bristle-moss (Orthotrichum rivulare)-a moss which, as we have seen, has a predilection for tree-roots and rocks by the water-side-the wall of this capsule, when dry, is marked by eight grooves or furrows, and consequently by the like number of ribs, or raised portions; these can easily be seen with the help of a good glass, and are very prominent in my magnified drawing. The number of these ribs in the capsules of this particular moss-and the same applies to other members of the same family -is never more nor less than eight, so that this feature naturally forms one of the characteristics by means of which the plant is recognised. But as soon as the capsule is moistened the ribs disappear, owing to the swelling out of the capsule wall, which is then marked by eight orange streaks. Fig. 14 of the same plate illustrates this condition; it shows a capsule in the moist state, from another member of the same family (Orthotrichum saxatile), which prefers rocks for its dwelling-place, especially when they are of a 
limestone nature. Fig. 2 of Plate IV.b is another illustration of a ribbed capsule. In the Hair-moss (Polytrichum) family a somewhat similar characteristic is found, the capsule wall, instead of being round, having a certain number of comparatively flat faces, with corresponding angles, varying in the different species from four to six, and running up the whole length of the capsule. A reference to Plate IV.a, fig. 13, will show more clearly what I mean.

Again, the position of the capsule with regard to the leaves varies in different plants, and affords a further guide in the naming of specimens. As a rule, the fruit-stalk is long, and thus the capsule is raised well above the leaves from the midst of which it springs; it is then said to be exserted, as in Plate II. figs. 9 and 10. But in many cases the fruit-stalk is so short that it does not lift the capsule above the level of the surrounding leaves, as in fig. 11 of the same plate, and here the capsule is consequently said to be immersed. Plate IV.a, figs. 4 and 5 are other instances of immersed capsules.

The latter figure also exemplifies, with exceptional clearness, a point in the structure of the capsule that may receive a passing word of notice. In many cases, 'when the capsule is examined with the microscope, a very distinct dark patch is seen in the centre of it, evidently betokening some part of the internal structure. This indi- 
cates the position of the spore-sack, inside which the spores are formed. Its deep colour is generally due to the fact that it is full of spores. In the capsule under consideration the walls are so thin that the form of the spore-sack is clearly distinguishable, even when it is empty. The same thing is also shown in figs. 13 and 15 of the same plate.

Stomata.-Before passing on, I must not omit to mention one feature which is peculiar to the capsules of certain of the mosses. It is of course well known that the microscope reveals, in the delicate skin of ordinary leaves, the existence of numerous tiny holes, through which air, water, and gases are constantly passing in and out of the body of the leaf. These are the pores, or stomata. Now, though nothing of the kind is found in the leaves of mosses, yet in the capsule wall of some species these pores are constantly present, being situated, as a rule, either near to the base or close to the mouth of the capsule. My readers will doubtless be aware that, in ordinary leaves, each of these tiny openings is surrounded by two crescent-shaped cells, known as the "guard-cells," which alter their shape somewhat, according to the condition of the atmosphere, and thus close or open the pore as outside circumstances may require. These guard-cells are also found encircling the pores of a moss capsule, as shown in Plate IV. fig. 23, which 
gives one from the capsule of the Wood Bristlemoss (Orthotrichum affine). In this instance the guard-cells are situated on the outer surface of the capsule wall, and the pore is said to be superficial; but in other cases they are formed just below the surface (Plate IV. fig. 22), and here the pore is said to be immersed. These pores are best seen in the members of the Bristle-moss (Orthotrichum) family, where they constitute a feature of some importance in determining the names of the various species, and it is always well, therefore, in examining one of these mosses, to ascertain at once, by dissecting one of the capsules, and viewing it under the microscope, whether the pores are superficial or immersed. Needless to say that a high-power lens will be necessary for such a purpose. I am not aware that any theory has ever been put forth as to the use which these pores serve, or to account for some being immersed while others are superficial.

Fruit-stalk.-I have already referred incidentally to the fruit-stalk, or seta, but this deserves a few more words of notice before we proceed, as it, too, has its own special characteristics. In colour it varies from pale green or yellow to brilliant crimson or warm brown; while, as we have just seen, it is sometimes long, in other cases comparatively short, and again, at times is so reduced in length as to be scarcely noticeable. It is either straight, with the capsule erect at its 
end (Plate III. fig. 15a); or it may take a more or less sharp bend just before it joins the capsule, in which case the latter is inclined or cernuous (Plate IV. figs. 4 and 6); or it may assume a more drooping form, when the capsule is described as pendulous (Plate III. fig. 21); while, in the more extreme instance given at Plate IV. fig. 3-the fruit-stalk and capsule of the Common Cord-moss (Funaria hygrometrica) -it is long and very flexible, and bends quite round upon itself. These various forms which the fruit-stalk assumes are further exemplified by figs. $6,7,8$, and 9 of Plate IV.a. Moreover, in some cases, when the stalk is examined with a good lens, the surface will be seen to be covered with numerous slight prominences, giving it a rough appearance. Plate IV. fig. 6, which represents the capsule and fruit-stalk of the Velvet Feather-moss (Brachythecium velutinum) well illustrates this, while at fig. 7 is a small portion of the same stalk more highly magnified, and showing the roughness much more clearly. Compare these two figures with figs. 4 and 5 of the same plate, in which are given the bent capsule and smooth fruit-stalk of another equally common moss, inhabiting similar localities; here the stalk is quite free from any sign of roughness. In some few instances we meet with fruit-stalks in which the upper part only is rough, while the lower portion is smooth, but such cases are comparatively rare. 
Once more-in certain mosses the fruit-stalk is strongly twisted, as in Plate IV. fig. 9, which gives the capsule and fruit-stalk of the Awlleaved Screw-moss (Tortula subulata), a frequent inhabitant of sandy banks, a small piece of the fruit-stalk, more highly magnified, being also depicted at fig. 10, where the twist in consequence is still more manifest. Features such as these further serve to show the importance, in every branch of nature-study, of the smallest detail, either in form or structure, and cannot but increase the wonder that we must feel as we recognise, at every step, the marvellous order that everywhere reigns.

Position of the Fruit.-It will not be inappropriate, before describing more minutely the various parts of the capsule, and the functions which they perform, to say a few words as to the position of the fruit on the plant, for this is a matter of some importance in the classification of the different genera, and is consequently a point which always has to be taken into account when searching for the name of any specimen under examination. Mosses are commonly divided into two large classes, according to this matter of the whereabouts of the fruit, namely, (1) those in which the fruit grows at the end of the stem, or acrocarpous mosses, and (2) those in which it springs from the side of the stem, or pleurocarpous mosses. Fig. 4 of Plate II. gives an 
acrocarpous, and fig. 19 a pleurocarpous plant. In the former class must be included those plants, of which there are not many, where the fruit is found growing from the end of short shoots, which branch off from the main stem. From a hard-andfast scientific point of view this classification is not accepted to the same extent as it formerly was; but the cases where it is not strictly applicable are so comparatively few, and are so unlikely to trouble a beginner that we may, for present purposes, disregard them. The distinction between these two general types of moss-growth is so clear, that the student will soon learn to recognise them, even in the field, without any difficulty, and this preliminary diagnosis will at once tell him among which genera he must search for the particular plant in question. Those mosses in which the fruit is produced at the end of the stem have a distinctly upright growth, and many of them frequently congregate in tufts or cushions, owing to the very nature of their mode of development; for the formation of flowers, and afterwards of fruit, at the end of the principal stem, stops its further increase in that direction, and the tendency consequently is to put forth new branches, and so to add to the size of the tufts. On the other hand, plants that have the fruit arising from the side of the stem are not subject to the same check to their elongation; and, as the stem thus tends to increase considerably in length, such 
plants naturally have a much less upright habit, and are far more given to creeping on the surface of the ground and to branching out in various directions. Hence it comes about that they commonly have a somewhat feathery appearance, from which fact it arises that so many of them are known as "Feathermosses."

The Lid.-The mouth of the capsule is usually closed by a tiny cap known as the lid (operculum). Plate III. fig. 21 represents the capsule of that frequent tenant of the woods, the Swan-neck Thyme Thread-moss (Mnium hornum), and here the lid is in position on the end of the capsule, while at fig. 22 the lid of the same moss is given after it has been removed. The lid may be either blunt, as in the instance just cited, or it may have a pointed end. And this pointed end may vary, from the very small one shown in fig. 4 of Plate IV.b, to the distinctly beaked lid in fig. 5, or the still longer one in fig. 6. (See also figs. 20 and 23 of Plate III.) Or, once more, the whole lid may be long and tapering, as in Plate III. fig. 15, which shows the capsule and lid of our old acquaintance the Wall Screw-moss (Tortula muralis), the lid itself being drawn at fig. 26. In this latter case, as we shall see, when we come to speak of the fringe of teeth round the mouth of the capsule, the form of the lid is necessitated by the peculiar construction of 
this fringe in the particular family to which this moss belongs.

It is hardly necessary to say that inside the capsule the spores themselves are formed. I do not propose to attempt to deal here with the manner in which they are developed, as such a task is clearly outside the scope of a small volume such as this. Those of my readers who may wish to go more deeply into the mysteries of what goes on in the interior of the capsule, will do well to consult Mr. J. E. Bagnall's "Handbook of Mosses," while they will find the subject dealt with in still greater detail in such a work as Hoffmeister's treatise on the Higher Cryptogamia. Suffice it for our present purpose to say, that in due time the spores are formed and ripen, and are then ready to be sown. Here Nature is her own sower, and very careful she is that the sowing shall be carried out to the greatest possible advantage in the interest of the plant. In many mosses there will be found round the mouth of the capsule, just under the lid, a ring of very special cells, which are larger in size than, and of a different form from, the cells of which the capsule wall is built up. These special cells constitute what is known as the ring, or annulus. Plate VI. fig. 1 is a drawing on a large scale of one of these rings, taken from the capsule of that common little moss, the Purple Forkmoss (Ceratodon purpureus), which, as already 
mentioned, grows almost everywhere, fruiting most abundantly in April and May. The ring is very susceptible to changes in the surrounding air, and in particular to the presence or absence of moisture; and so it happens that when the spores are ripe, and the outside conditions are favourable to their growth, it suddenly rolls back, and in so doing will sometimes even force off the lid, or at all events will so far loosen it, that the next gust of wind may suffice to completely remove it, and thus the spores are in many cases free to escape. It will easily be imagined that this ring of cells is extremely minute, so minute indeed that it is hardly visible unless considerably magnified. Fortunately in the moss to which I have just referred it is especially large and prominent, so that it is quite possible with the help of a good magnifyingglass and a fine dissecting-needle, and with the exercise of some amount of care and patience, to disentangle it from the mouth of the capsule, and to lift it into the mounting medium, and thus to obtain a very interesting microscopic slide. If some of the capsules of this moss are examined about the middle of May the unrolling of the ring may be seen, a slight pressure on the cover-glass often sufficing to bring this about. Plate VI. fig. 2 is a drawing of a capsule in which the ring has just uncoiled, as appears from the somewhat frayed or ragged appearance of the edge 
of the capsule mouth. It will be noticed that in the process the lid itself has not only been loosened, but has been distinctly raised some little distance, and is now probably in such a position that it would be easily blown off. As showing the extreme sensitiveness of the cells of which the ring is formed I may mention that when, in the process of mounting a slide, one of the rings has been transferred from the end of the capsule to the preparatory fluid more particularly referred to in Chapter IV., I have seen it twist and skip about for some little time as though it were alive, owing, no doubt, to the violent contraction of the cell-walls, brought about by the glycerine in the fluid.

In many mosses the ring is absent, and here the lid is gradually pushed off by the growth of the capsule itself; in other plants there is no lid at all, and here one of two things generally happens-either the walls of the capsule burst when the spores are ripe and ready to escape, or the capsule itself falls to the ground and its walls decay, thus eventually freeing the spores. Plate III. figs. 24 and 25 show the tiny round capsule, surrounded by the lance-shaped leaves of the diminutive Pointed Earth-moss (Phascum cuspidatum). This capsule is devoid of a lid. When ripe it turns a beautiful warm brown, and is then readily detached from the stem, and its walls, being very thin and fragile, easily rupture 
when the time comes for the liberation of the spores. Fig. 11 of Plate IV.b-the capsule of the tiny Serrated Earth-moss (Ephemerum serratum), a plant already alluded to more than once-is another similar instance.

One small family of mosses calls for special notice, as the manner in which their capsules open is very peculiar, and approaches, as we shall hereafter see, so closely to the method adopted by the liverworts, that it would seem that we have here a kind of link between the two tribes. The mosses that I refer to are known by the family name of Andrecea, after one Andrea, an apothecary of Hanover. They make their abode in the crevices of certain kinds of rock, and, being fond of high and exposed situations, are mainly confined to the peaks of our higher mountains. The striking feature with regard to these little mountain mosses is, that the capsule wall opens by means of four cracks or slits, and it is through these slits, which open in dry weather and close when moisture is present, that the spores when ripe are allowed to escape. Plate VI. fig. 3 is a drawing of a ripe but closed capsule of one of these mosses, the Black Falcate Andreæa (Andreaa Rothii), which generally inhabits mountainous regions, often growing on the face of a rock, exposed to the full blaze of the sun, where to all appearances it would seem to be without the means of bare subsistence. The grooved markings on the capsule 
wall show where the slits will presently appear, so soon as the time arrives for the spores within to be discharged. Fig. 4 of the same plate represents a dry capsule of another moss belonging to this family, the Alpine Andreæa (Andreca alpina), which flourishes in still higher altitudes, and here the capsule wall has split open in the manner described, and the spores have fallen out. At fig. 5 we have a somewhat damaged capsule (drawn in the moist state) in which three of the four pieces into which the capsule has divided are still held together at their upper ends, the fourth having broken away. Figs. 13 and 12 of Plate IV.b show the closed and open capsules of another member of this family. There are, in all, only some four or five British species, and, owing to their preference for high localities, they are not at all common in these islands; but in other parts of Europe, and especially in Scandinavia, which seems to be their favourite haunt, they are much more abundant. Though in form and colouring they are not perhaps so attractive as many of their brethren of the moss world, yet to the nature student a special interest attaches to them from the facts above detailed, and others of a like nature to which I shall have occasion to refer more fully hereafter.

Having started with a spore we have now returned to the spore again, and thus the narrative which I set out to tell would seem to be com- 
plete, for, in one or other of the ways above described, the spores may be freed, to begin again the never-ending circle of plant-growth. I trust that, even so far, enough has been said to show that these unpretentious little plants have a tale of their own to tell which may well claim a hearing from all nature lovers. As has been so well written:

The tiny moss, whose silken verdure clothes The time-worn rock, and whose bright capsules rise, Like fairy urns, on stalks of golden sheen, Demands our admiration and our praise, As much as cedar, kissing the blue sky.

We have not, however, by any means yet come to the end of our story, and, indeed, some of the most wonderful parts of it have still to be told. But before passing to them let me pause for a moment, in order to point out certain broad and important distinctions that exist between the mosses and so-called "flowering plants," both as to the period in the plant's history at which fertilisation takes place, and also as to the particular results that fertilisation brings about; for while in both cases the goal is the same, namely, the production of fruit, it is reached by very different routes. In an ordinary flowering plant, such, for instance, as the common white lily of our gardens, the seed, when sown, produces a stem, on which are formed, first a succession of green leaves, and ultimately, at its end, a 
cluster of buds, each one of which in due course opens into the beautiful snow-white blossom that one knows so well. In the centre of this we find a number of long green stalks, each with a dark brown head (the stamens), and these surround a thick green pod (the pistil), inside which, if we cut it open, we may see the unripe seeds, from which future lilies are to spring. It is at this stage in the life of the plant that the fertilisation of these unripe seeds in the pistil is effected, by means of the small yellow grains of pollen from the heads (anthers) of the stamens, which grains contain the wonderful fertilising matter, without the assistance of which the seeds would never ripen, let the season be ever so favourable, and the plant be supplied with the best possible nutriment. In a moss, on the other hand, the spore gives rise to a plant, which, as we have seen, bears leaves and reproductive organs, but until fertilisation has taken place the reproductive organs will produce no fruit-vessel, and consequently no spores. The result of fertilisation in this case is that the fruit-vessel, or capsule, makes its appearance, and inside this the spores are developed and ripen, without any further assistance, beyond what is afforded by the ordinary food taken in by the plant. In the one case, to put it shortly, fertilisation brings about the ripening of the unripe seeds which have already been formed in the fruit-vessel, while in the 
other it effects the growth of the fruit-vessel, containing the minute round bodies which ultimately develop into the ripened spores.

The Peristome.-But to resume our story. So careful is Nature in the matter of the sowing of the spores, that she generally takes special precautions to ensure their due dispersal. In most mosses the fall of the lid discloses round the mouth of the capsule a fringe of the most exquisitely delicate teeth, known as the peristome, a name derived from two Greek words, meaning "around the mouth." No words of mine would suffice to give any adequate idea of the extreme beauty of this marvellous structure, which forms by far the most fascinating part of a moss; to be appreciated it must be seen, and to see it in full perfection a microscope is essential, for it is only when considerably magnified that its wondrous organisation, and its extraordinary delicacy can be even faintly realised. It is doubtless owing to this very fact that the peristome of a moss is one of the stock objects for microscopical examination, recommended in elementary books on the instrument. At the same time, a very fair idea may be obtained of the nature of this beautiful organism, by the help of nothing more pretentious than a good, strong magnifying-glass, more especially if we know beforehand something about its form and structure, and can consequently be on the look-out for 
its characteristic features; a remark, by the way, which applies with greater or less force to practically every part of a moss. The teeth of the peristome, like other portions of the plant that we have met with, are very sensitive to the presence or absence of moisture in the atmosphere, and open or close according to the influence which is thus exerted upon them. Its function is supposed to be to control the escape of the spores from the capsule, either by closing down, and so shutting them in, should the state of the surrounding air be unfavourable to their germination, or by standing erect, when outside conditions are such as to promote their growth. Plate V. fig. 1 shows, on a somewhat large scale, the peristome of the beautiful capsule of the Swan-neck Thyme Thread-moss (Mnium hornum), and fig. 9 of Plate IV.b gives the entire capsule. In both cases the teeth are standing erect, while in fig. 6 of Plate V. the peristome of the Dwarf Swan-neck Moss (Campylopus pyriformis), they are even bent back (recurved). On the other hand, in fig. 2 of the same plate, which gives the peristome of the Velvet Feather-moss (Brachythecium velutinum), they have closed down over the capsule mouth.

The number of teeth of which the peristome is composed is always either four or a multiple of four. There are only two British species in which we find so few as four; and though one of these, the 
Pellucid Four-tooth Moss (Tetraphis pellucida), as it is called, in consequence of the special form of its peristome, is often common enough, growing on rotting wood, or on peaty ground, it seldom fruits with us. Plate V. fig. 7 is a drawing of the peristome of this moss, taken from a plant that I gathered many years ago in the Alps; while at fig. 8 of Plate IV.b is one of the capsules of the second of the two species just alluded to, which again shows the four peristome teeth. Most mosses have either eight, sixteen, thirty-two, or sixty-four peristome teeth; but whatever the number may be, it is invariably the same in all the capsules of any one species, and this feature in moss-structure will, in consequence, often prove a valuable guide to the identity of some particular moss. One could not well have a more striking instance of the wonderful order and exactness of Nature's methods than this fact, that the number, aye, and generally too the colours and markings of these wonderful teeth-details most of which, be it remembered, cannot even be seen except when a lens of high magnifying power is used-remain constant in any one species of moss, wherever on the face of the globe it may be found.

Illustrations of this very interesting point are given in figs. 6 and 8 of Plate V.a, where I have drawn a few teeth taken from two members of the great Thread-moss (Bryum) family. These 
two mosses so much resemble each other that it is frequently a matter of great difficulty, in the absence of fruit, to distinguish them. But if the ripe capsules happen to be present no such difficulty arises. For, while in the one case (fig. 8), the teeth of the peristome, when highly magnified, are seen to be marked with a delicate net-work of lines, in the other (fig 6) this network is absent, and we have only the ordinary transverse bars, with a curious zig-zag line down the centre of the tooth, caused by the shape of the ends of the cells of which it is formed.

In many cases there are two sets of teeth, an outer and an inner peristome, which, of course, constitute a still further check on the escape of the spores. Plate IV. fig. 11, and Plate V.a, fig. 10, where the ends of the capsules of two of the Feather-mosses are given, offer good examples. In both cases the drawing has been made from a dry specimen, because then the teeth of the outer peristome are rolled over, so as to disclose the inner fringe. At fig. 11 of Plate V.a will be found what is, perhaps, the most beautiful peristome of all our British mosses, namely, that of the Greater Water-moss (Fontinalis antipyretica), which, as implied by its name, grows in water. Its long stems, clothed with the curious pointed leaves, each one with the two sides folded together down the centre, in the manner so peculiar to the plant, may be met with in streams 
and ponds, often attaining a very considerable length. I have seen its slender dark green tresses streaming out from some stake in a river to which they were attached, to the distance of a couple of feet at least. When thus living in the water it seldom fruits; but if, as sometimes happens in a season of drought, it is left on the mud by the side of a pool, or on the bank of a stream, the capsules will often be produced in abundance, and such an opportunity of obtaining objects for microscopical examination is one not to be missed.

The inner peristome in this instance can hardly be said, in any sense, to be formed of teeth. In the microscope it has all the appearance of being composed of a number of fairy ladders set on end. In the outer fringe the teeth are long and much broader, thus strikingly setting off the delicate inner structure. When seen in the microscope the whole forms an object of extreme beauty.

On the other hand, some mosses-though they are in a distinct minority-have no peristome (Plate IV.b, fig. 15), and then, of course, the spores are free to escape on the fall of the lid.

Plate V. fig. 5 will perhaps help to explain more clearly the manner in which the peristome acts. It represents a slice cut off the end of one of the tiny round capsules of the Common Apple-moss (Bartramia pomiformis) (see page 48). This has been mounted so as to enable us to look down 
upon it, and thus to obtain a bird's-eye view of the capsule mouth. Looking at this in the microscope with a somewhat high-power lens, we see what I have tried to give in my drawing, namely, a small portion of the upper part of the capsule wall, and in the centre of this the round mouth of the capsule. Over this mouth the sixteen teeth of the peristome will be observed, closing down so as to almost fill up the aperture, each tooth being strongly marked with a number of parallel bars across its face. Some of these teeth were evidently on the point of rising when my mount was made, for their ends have been bent back by the cover-glass used to seal the slide, as indicated by the shaded portions in the figure, We thus have an opportunity of getting a glimpse into the inside of the capsule; and here we notice, just below the outer surface, the still more delicate and transparent teeth of the inner peristome, this capsule being an instance of one that is provided with a double set of teeth. Under certain conditions of the atmosphere, both sets of teeth will stand erect round the capsule mouth, and thus a free passage will be made for the spores to find their way into the wide world outside. I have shown this condition of the peristome, on a somewhat larger scale, and consequently more clearly, at fig. 5 of Plate V.a, which represents the top of the capsule of that member of the Bryum family (Bryum pendulum) 
to which I alluded when speaking of the markings on the peristome teeth (p. 71). Here, again, the teeth-sixteen in number-are shutting down over the capsule mouth, and so closely do they fit together that sufficient space is not left between them even for the tiny spores to force a passage.

In not a few mosses the mouth of the capsule is closed in a different manner. Plate V. fig. 3 gives the upper portion of the capsule of that large-leaved, shade-loving moss that we have already noticed as growing in the woods, or on the shady banks of a country lane, the Wavy-leaved Hair-moss (Catharinea undulata). It will be seen, from the drawing, that the teeth of the peristome are much shorter than those which we have hitherto examined, so short, in fact, that when closed they would not meet over the mouth of the capsule. The same thing may be seen even yet more clearly in the large brown capsules of the Common Hair-moss (Polytrichum commune), so plentiful on heathlands and commons, for here the capsule mouth is very large, and the teeth of the peristome-sixty-four in numberare very small indeed. In such cases it would at first sight seem as though Nature's object had either been frustrated or that she had not exercised the same amount of care to guard against the too early escape of the spores, as in so many other instances. A closer examination 
will, however, soon convince us that this is not so, and that, on the contrary, special means have been taken to meet special circumstances, in the shape of a very delicate round membrane resembling a diminutive drum-head, and probably from this resemblance called the tympanum (the Latin name for a tambourine or drum); this in reality forms the end of a small rod or column, known as the columella, which occupies the centre of the capsule, and round which the spores are formed. This delicate membrane, then, fills up the space which is left uncovered by the peristome teeth, and thus the mouth of the capsule is effectually closed, the spores, when ripe, being allowed to escape through the spaces between the teeth. This is illustrated by figs. 10 and 14 of Plate IV.b, while at Plate V. fig. 4 the tympanum is in position, and the peristome teeth are closing round it; fig. 10 of the same plate gives the larger tympanum of the Common Hair-moss (Polytrichum commune), and the notches in its edge show where the peristome teeth have been attached. Such is yet another instance of Nature's care for the welfare of her children.

In many mosses the peristome, instead of being formed of teeth, consists of a number-still always a multiple of four - of long and extremely fine hair-like bodies, which are twisted into a beautiful coil or spiral. At fig. 10 of Plate II. is a drawing of the capsule of the Wall Screw-moss (Tortula 


\section{MOSSES AND LIVERWORTS}

muralis), and at its upper end will be seen the twisted peristome which is so characteristic of most of the members of the family to which it belongs. It is, no doubt, to the screw-like peristome that these particular mosses owe their specific name of "Screw-mosses," and its peculiar form of course necessitates the cylindrical lid referred to on page 60 . This peristome is given on a much larger scale in Plate V. fig. 8, which is some twenty-six times larger than the original. It may easily be seen, with the help of a good glass, on almost any mossy wall in the winter or early spring, and forms an object for microscopical examination that is ever full of wonder and beauty. I have added, in Plate V.a, figs. 1 and 2, two further illustrations drawn from the Bird's-claw Screw-moss (Barbula unguiculata), in which we have, perhaps, the most beautiful example of this twisted form of peristome.

As a matter of fact, the lower portions of the hairs of these screw-like peristomes are united into a kind of tube, though in most cases this tubular part is so short as hardly to be noticeable. Sometimes, however, it is much longer, as in the peristomes figured at Plate V. fig. 9, and Plate V.a, fig. 3, both taken from the Awl-leaved Screwmoss (Tortula subulata), which, as already mentioned, is far from being uncommon, growing on sandy hedge-banks, and often producing in the summer a plentiful crop of specially large cap- 
sules, each at the end of a strongly twisted stalk (seta). In this case the tubular portion of the peristome is even longer than the upper part where the hair-like growths are free. It is delicately marked, as I have endeavoured to show.

We will now see, with the help of Plates V. and V.a, what some of the various peristome teeth look like under a fairly high power in the microscope. We shall at once notice, even if the fact has hitherto escaped us, that they are brilliantly coloured, either some shade of golden-yellow or crimson, or a combination of these two colours, and moreover that they are marked with the most delicate tracery of lines and bars. As I have already had occasion to mention, these markings, though so minute as to be only visible at all when the teeth are highly magnified, are nevertheless so constant as sometimes to constitute a feature by means of which a particular species may be distinguished from another, otherwise almost similar, member of the same family. Fig. 11 of Plate V. gives us some teeth of the Silky Pendulous Thread-moss (Webera nutans), a moss that grows in fair abundance on sandy banks and heaths, maturing its large pear-shaped capsules, each on a bright red stalk, in May or June. These teeth are a deep yellow in colour, and, as will be seen, are marked with conspicuous bars. The second or inner peristome is also shown in the drawing. At fig. 14 of the same plate we have two or three 
more of the teeth taken from the same moss, but here they have purposely been drawn in profile, and we then see, by their somewhat jagged outline, that some of the bars are evidently raised above the other parts of the teeth, in relief, so to speak; this is shown very clearly in the tooth on the extreme right. Fig. 12 of the same plate represents a few of the small teeth from the capsule of the Wavy-leaved Hair-moss (Catharinea undulata), and here the markings follow the outline of the teeth themselves. These teeth make extremely beautiful objects for the microscope, being coloured a bright golden yellow, marked and picked out in various shades of crimson. The teeth drawn at fig. 13 (as also, on a larger scale, at Plate V.a, fig. 13) are throughout of a deep crimson colour. They are, moreover, delicately marked and barred, and each tooth, it will be noticed, is cleft down the centre into two distinct portions, which, towards the base, are connected at various points by transverse bars; they are taken from the long, oval capsule of the Broom Forkmoss (Dicranum scoparium), already referred to, a dweller on shady banks and in woods. Fig. 7 of Plate V.a is a tooth of the beautiful capsule of the Swan-neck Thyme Thread-moss (Mnium hornum), and, again, is tinted a bright golden yellow. The one drawn at fig. 9 is taken from the Sessile Grimmia (Grimmia apocarpa), to which plant I shall have occasion to refer again later on. The 
colour, in this instance, is a peculiarly rich crimson. It will be noticed that the tooth is pierced by two tiny holes, so small, indeed, as only to be visible when a fairly high magnifying power is used. This feature, though so minute, is practically constant, and may sometimes form a useful aid in identification. In such a case the teeth are said to be cribrose. Fig. 12 of the same plate shows a few teeth of both the outer and inner peristome of another member of the Bryum family (Bryum murale), and will give some idea of the form that the inner peristome commonly takes.

I have before referred to the fact that the teeth of the peristome are very sensitive to changes in the atmosphere, being easily affected by the presence or absence of moisture; as a rule they open when the air is damp, and close when it is dry, as, indeed, we might not unnaturally expect them to do, judging from the moisture-loving nature of these little plants. Not unfrequently, however, we come across a case precisely the reverse of this, and in which, as soon as a dry capsule is moistened, the teeth of the peristome, which but a moment before were standing erect, will close down tightly over the capsule mouth, as if to effectually shut in the spores. Plate IV. fig. 12 is a capsule of the Sessile Grimmia (Grimmia apocarpa), a moss which grows in drylooking tufts of an olive-green colour, on walls and rocks, often choosing the uppermost stones of some 
wall, where, one would imagine, it would find considerable difficulty in getting sufficient nourishment to keep life going; yet here it will flourish and produce an abundance of fruit. My drawing was made from a perfectly dry capsule, and still the peristome teeth are standing erect. I know of no more beautiful sight of its kind than a tuft of this moss, when seen through a good magnifyingglass, as I saw the small colony of plants from which my specimen was gathered, growing on a wall in Dove Dale, one typical March day, with a keen east wind blowing, and everything looking so pinched and dried, that it was difficult to believe that the dark, shrivelled substance on the stone before me had any life left in it. A glance through the lens, however, soon showed that it was very much alive, for nestling among the dusky leaves could be seen numbers of these beautiful little capsules, in various stages of development, many of them with the teeth of the peristome standing erect, like so many dainty coral stars. But let a shower of rain come, and these coral stars would disappear, owing to the closing down of the peristome teeth.

In many of the members of the Bristle-moss (Orthotrichum) family we may see the open peristome under dry conditions shown much more clearly. Thus, fig. 4 of Plate V.a gives the top of a capsule of the Wood Bristle-moss (Orthotrichum affine), and here the teeth are actually bent back, 
right over the edge of the capsule mouth. This is a sight that may often be seen, by scrutinising the green tufts nestling in the crevices of the bark of such a tree as the sweet chestnut or the wych elm, with a good magnifying-glass.

We are naturally led to ask the why and the wherefore of facts such as these; for when we find them happening with never-failing regularity, we may be pretty sure that there is some very practical reason for their occurrence. Sir Edward Fry, in his delightful book entitled "British Mosses," suggests that the possible explanation may be that, whereas in many mosses the spores germinate best under the influence of moist surroundings (and here the peristome opens in wet weather and closes in dry), in other cases dry conditions are most favourable to their development (and here the peristome teeth only stand erect when the atmosphere is free from moisture). If this suggested explanation of somewhat remarkable facts is the correct one, it certainly affords a very marvellous instance of adaptation to surrounding circumstances, brought about, one must presume, by the operation of the principle of natural selection.

Summary of Life-history.-Before proceeding to speak of the more special modes of reproduction that we meet with, I propose, with the help of Plate I., to focus the contents of the foregoing pages, by shortly summing up the various steps 
by which we have, so far, advanced, and thus to give a concise view of the story of moss-development. And such a survey will, I think, be rendered all the more interesting if we confine ourselves to one species of moss. There is none that will better answer this purpose than the Purple Fork-moss (Ceratodon purpureus), which, as before mentioned, is one of the most familiar figures of the tribe. There will practically never be any difficulty in meeting with it in nature, for on almost any roadside bank or expanse of waste ground in the country it is almost certain to have taken up its abode; though, naturally, if we wish to see it in some particular condition, the appropriate season must be chosen.

Let us start with the bud-like flower (fig. 1) which has sprung from the thread-like protonema, which in its turn was developed from a spore; this may be sought in the late summer-time. It will contain the curious sausage-shaped fertilising organs (antheridia), some of which will probably be ripe (fig. 2), while others will already have discharged their contents (fig. 3). The fruitbearing organs (archegonia) are not so readily discovered, as they are somewhat sparingly produced. However, a careful search among the leaves of the plant under the dissecting-microscope will generally prove successful, and an examination of one, with a fairly high magnifying power, will clearly show the passage down the 
slender neck, and the cavity in the base, containing the specialised cell (oosphere), from which the fruit is to originate (fig. 4). The two fruitbearing organs given at fig. 5 illustrate the unfertilised and the fertilised conditions. In the autumn we may alight on specimens of this same organ which have advanced considerably further (fig. 6), and where, owing to the development, inside, of the young spore-vessel, the swollen base has become so much enlarged as to have quite lost its original form. The remains of the slender neck, however, at its upper end, will conclusively prove its true character.

All through the winter, when nature, in general, seems to be asleep, there is little, if any, suspension of operations in the moss world, and, long before the first welcome days of spring, the green cushions on the hedge-bank will bristle with numberless delicate yellow stalks, each of them tipped, as a peep through the glass will demonstrate, by the long tapering veil (calyptra) (fig. 7), while, on cutting away the leaves at the base, the sheath (vaginula) will be found, encircling the lower portion of the stalk (fig. 8). Later on, the young capsule has begun to assume a more characteristic appearance (fig. 9), and soon the veil is pushed or blown off. A search with the glass among the leaves will often disclose some, lying about, that have been thus discarded (fig. 10). By and by, each bristling 


\section{MOSSES AND LIVERWORTS}

stalk will be tipped with a small brown head, indicating that the capsule has arrived at maturity, and on placing one of these, in a moist state, under the microscope, the slight swelling at the base, alluded to in a previous page (p. 52), will at once become apparent, while the capsule mouth is closed by the lid (operculum), thus precluding the escape of the ripe spores inside (fig. 11).

It will not be long now before the ring of cells (annulus) just under the lid, which has also been described (p. 61), comes into play (fig. 12), and, rolling back, will lift the lid from the capsule mouth, and so render it possible for the spores to make their way out (fig. 13). The lid (operculum) itself, when thus freed, forms a pretty object under the microscope (fig. 14), and its fall, of course, brings to view the fringe of teeth (peristome), which guards the entrance to the interior of the capsule. These particular teeth are especially attractive, and will well repay a closer acquaintance. Let us see what they look like under different conditions.

And first we will examine a dry capsule (fig. 15) with a glass. Notice, in passing, its curiously furrowed walls, so unlike their appearance when the capsule has been moistened (fig. 11). The teeth of the peristome, it will be seen, are closed over the capsule mouth, this being a case in which they only open under the influence of moisture. It will be well, moreover, to get a 
sight of the peristome, in this state, as an opaque object in the microscope (fig. 16), in order to see the delicate tracery of the pale straw-coloured teeth more distinctly.

But now soak a few of the capsules in a little warm water (notice how quickly their shrivelled appearance disappears), and again bring the microscope to bear on the upper end of the capsule, this time, however, with transmitted light. A decided change has evidently taken place, for the teeth of the peristome, which a minute before were bending down over the mouth, are now standing erect (figs. 17 and 18), and have taken on a brilliant golden hue, toned and picked out with crimson. And if a few of them are cut off, and subjected to a much higher magnifying power, the markings become all the more clear (fig. 19); while it will also be observed that each tooth is deeply divided into two long and narrow portions, which, at their lower ends, are connected by transverse bars, also crimson and gold. Well might Dr. Braithwaite say, in his "British Moss Flora": "We would advise all commencing bryologists to study every part of this moss well, as its structure, once familiarised to the eye, will save much after trouble, and the beautiful peristome must attract every microscopist."

Reproduction otherwise than by Spores.-We have, so far, dealt with what I may call the normal mode of reproduction of mosses; but 
Nature is by no means bound by hard-and-fast lines such as these, and very often takes an extremely short cut to attain her ends; indeed, in no other part of the vegetable kingdom does she evince so many resources in this matter of reproduction, as she does in this particular corner of it. I can only give a glance at a few of what we may call her special methods of procedure.

Many mosses seldom produce fruit, and yet flourish and multiply abundantly. For instance, the so-called Frizzled Bristle-moss (Ulota phyllantha), which grows in dense cushions on trees and rocks, generally in the neighbourhood of the sea, has a world-wide distribution; but, though it is thus so well known, its fruit has very rarely been seen in any part of the world. Other plants could be named to which the same remarks would apply with almost equal force. Now, in all these cases it is pretty clear that some method of increase must be adopted, or otherwise the plants in question, instead of being widespread and plentiful, would ere this have become extinct. There are several ways in which mosses reproduce their kind without the assistance of spores. The most familiar of these consists of the formation on the plant of small bud-like bodies, or gemmæ, as they are called; these occupy different positions in different species. For instance, when speaking (p. 70) of that pretty filmy green moss, the Pellucid Four-tooth Moss (Tetraphis pellucida), 
as an instance of a moss having a capsule with only four peristome teeth, it was mentioned that, although it may often be found growing in considerable profusion on peaty banks and rotting wood, it rarely fruits in this country. When one of these tiny plants is examined under the microscope, it will usually be found that the stem is crowned by a cluster of specially large leaves, forming a beautiful leafy cup (Plate VI. fig. 7), through the filing half-transparent sides of which a number of dark, round bodies may be indistinctly seen lying inside. These are the bud-like bodies, or gemme, just alluded to, and it is through their instrumentality that the moss is usually multiplied. Figs. 8 and 18 of the same plate give some buds highly magnified. Again, the Bud-headed Thread-moss (Aulacomnium androgynum, Plate VI. fig. 9) is a bright green moss that may not unfrequently be seen, covering considerable portions of the hedge-banks by the roadside, or clinging to some rotting tree-stump; but, comparatively common as it is, its fruit is rare, and consequently it, too, cannot look altogether to the spores as a means of preserving the species. If we examine a colony of these plants somewhat more closely, we shall probably at once be struck by the fact that it literally bristles with numerous pale green stalks, and, with the help of a glass, we shall further find that each of these tiny stalks is tipped with a 
small round head, as in my drawing. If this round head is still further magnified (fig. 10), it will be seen that it is made up of a great number of minute, egg-shaped bodies, packed very closely together. These again are gemma, and a few of them, on a considerably large scale, are given in fig. 11. Plate VI. fig. 14 shows a leaf of the Roughish-leaved Screw-moss (Tortula papillosa), a name given to the plant by reason of the fact that the surface of the leaf is roughened, or papillose, a condition which is by no means confined to the leaves of this particular species. This moss, which grows in dark, olivegreen tufts on the trunks of trees, is, I believe, never found in fruit in Britain, and new individuals arise by means of bud-like growths, which are developed on the upper faces of the leaves, clustering round the midrib, or nerve, as shown in the drawing; fig. 17 represents a few of these bodies more highly magnified. In the Frizzled Bristle-moss (Ulota phyllantha) referred to not long since, the buds are formed in a cluster at the very tip of the leaf, and have all the appearance, at first sight, of some brown fungoid growth.

Now, in all such cases, if one of these tiny bodies falls to the ground and begins to grow, it gives rise to that curious thread-like growth (protonema) which, as we saw at the outset of our story, is usually the first stage of the 
development of a moss from the spore. We may often see this well illustrated in the microscope in the case of the Pellucid Four-toothed Moss (Tetraphis pellucida); for here, so anxious do these small bud-like bodies seem to be to take up their life-work, that the thread-like growth (protonema) frequently shows itself even before they have fallen out of the leafy cup in which they are originally formed.

Plate VI. fig. 15 is a drawing of a leaf of the moss known as Lyell's Bristle-moss (Orthotrichum Lyellii), which makes its abode on the trunks of trees. Its leaves, when closely examined, will be seen to have a number of small brown bodies growing upon them; these are easily visible by the help of an ordinary magnifying-glass, and may even, when present in large numbers, as is frequently the case, be made out by the unassisted eye. They are really the beginnings of the thread-like protonema itself, and sometimes attain a considerable length while still clinging to the plant. A few, on a larger scale, are given at fig. 16.

The pale-fruited Thread-moss (Webera annotina, Plate VI. fig. 12) is another instance of a moss which is very rarely met with in fruit, and yet is by no means uncommon. In this case small bulb-like bodies are produced in the axils of the leaves; these, when sown, will also give rise to the thread-like protonema, from which again fresh 
plants may spring. Three of these "bulbils," more highly magnified, are shown at fig. 13 of the same plate. In all these cases it is evident that, as some of the ordinary stages of development are omitted, the circle of the plant's lifehistory is completed more speedily and directly than where, starting with the spore, the various steps that we have been tracing-culminating in the ripened capsule-are one by one followed out; for we have a plant producing buds, which in their turn give rise to the thread-like protonema, from which fresh plants may spring, bearing buds, which are ready to begin again the same round of life. Here, then, the reproductive organs, capsule, and spores are absent, and the process of reproduction is effected in a far simpler manner. Sometimes we even find a young moss plant springing direct from one of the leaves of the mother plant, when, of course, all intermediate stages are omitted, and we may have plant succeeding plant in endless succession. These instances will serve to show Nature's marvellous fertility in this particular part of her wide domain ; indeed, when one realises the apparently almost infinite possibilities for multiplication which these little plants possess, one is tempted to wonder that there is any room left on the face of the earth for anything but mosses !

Leaves.-In the course of what has already been said, reference has frequently been made to 
the leaves of the various plants described; but this particular portion of moss-structure deserves something more than a mere passing notice, for not only is the leaf important in the economy of the plant, but its form and structure generally constitute clues of no little value in the diagnosis of any particular specimen, while it is at all times an object of beauty for microscopic examination. We have already learned enough, I think, to realise that there is a great diversity, both of size and form, to be met with in moss leaves, a fact that will be still further emphasised by a glance at Plate VII., where more than thirty different leaves are depicted. It is manifestly impossible to refer in detail to every one of these, but a few examples may be taken as illustrating some of their general characteristics.

In size, moss leaves may vary from the tiny one given at fig. 13-which would appear as nothing more than the merest speck, when seen by the unassisted eye-to the far larger and easily recognised one at fig. 22. In form they may be long and narrow (fig. 20), lance-shaped (fig. 11), eggshaped (fig. 8), spoon-shaped (figs. 16 and 25), etc. ; the apex may be blunt (fig. 8), or tapering (figs. 2 and 10), or ending in a small point (fig. 22), or in a long point (figs. 18, 23, and 31). The edge, too, may be plain (fig. 19), bordered (fig. 22), toothed (figs. 6, 11, 12, and 28), bordered and toothed (fig. 29), wavy (fig. 32), rolled-back, 
or recurved (fig. 25), etc. In some the midrib, or nerve, as it is called (and observe that there are never any branching ribs or veins in a moss leaf, as in most ordinary leaves, only the one central nerve), reaches the whole way up the blade or lamina of the leaf (figs. 19 and 22); in others it is even extended beyond the end of the leaf (when it is said to be excurrent) (fig. 16), or this extension may take the form of a long, transparent hair-point (figs. 3 and 25). In others, again, it ceases before reaching the end of the leaf (figs. 14 and 18). In some cases it is forked or double (figs. 7, 8, and 12); while sometimes it is absent altogether (figs. 4 and 5). Some mosses, moreover, produce very different forms of leaf on the same plant; for instance, the leaf drawn at Plate IV. fig. 15 was taken from the stem of the Common Rough-stalked Feather-moss (Brachythecium rutabulum), a well-known moss, with bright, sheeny green leaves, that grows freely on banks, walls, tree-roots, etc., and produces an abundance of pretty, red, egg-shaped capsules in the winter; fig. 16 gives the form of leaf peculiar to the branches of the same moss; while at fig. 17 we have one of the special leaves which surround the base of the fruit-stalk (known as the perichotial leaves), which, it will be seen, has a distinctly different shape from either of the other two. Occasionally the leaves that spring from the lower portion of the stem vary considerably 
from those produced on the upper part, though this is not by any means of frequent occurrence.

With regard to the curious hair-point to the leaves of certain mosses-a very good illustration of which is to be found in the dark green, spoonshaped leaves of our old friend the Common Wall Screw-moss (Tortula muralis) - this varies in length in different species, being sometimes so long as to impart quite a hoary appearance to the tufts, as, for instance, in the case of the well-known Grey-cushioned Grimmia (Grimmia pulvinata, Plate II. fig. 13). The microscope discloses that, in some cases, it is quite smooth, as in the one drawn, on a large scale, at Plate VI. fig. 20, from a leaf of the Wall Screw-moss (Tortula muralis); while in others its surface is roughened owing to the presence of minute teeth, as at fig. 21 of the same plate, taken from a leaf of another member of the same family. In one British moss the apex of the leaf is still more specialised, for it terminates in a curious double hook, thus enabling us at once to recognise this particular species. This moss is known as the Pendulous Wing-moss (Antitrichia curtipendula); it grows chiefly on rocks and trees in mountainous districts. A leaf is given at fig. 26 of Plate VII., and the apex more highly magnified, and showing the double hook, at fig. 30 .

The surface of the leaves is not unfrequently roughened, owing to the fact that each cell is 
slightly raised in the centre, thus forming a minute excrescence. These papilla, as they are called, are best seen, either when the leaf is viewed in profile, or when the margin is turned inwards or outwards, and, needless to say, a lens of considerable magnifying power is required for the purpose. At Plate IV. fig. 24 a portion of the leaf of the Smaller Hairy Screw-moss (Tortula lavipila), a tree-loving plant, is given, magnified fifty-one times, and here the roughened surface due to the presence of these papilla is very clearly shown. Another instance of the same thing is depicted at fig. 25 of the same plate, from the leaf of the Spiral-fruited Extinguisher-moss (Encalypta streptocarpa), a frequenter of limestone walls and banks; while at fig. 26 a small piece of one of the same leaves is figured, still more highly magnified.

Another point of interest to be noticed in connection with the leaf is, that it always grows directly on the stem or branch, and is never provided with a leaf-stalk, like the leaves of our trees and shrubs. In some cases the base of the leaf is continued, on each side, for some little distance down the stem or branch on which it grows, and is then said to be decurrent (i.e. running down), a feature of much importance in the identification of many mosses.

Paraphyllia.-In some of the Feather-mosses (Hypnacea), in addition to leaves, the stems bear 
a number of very minute leaf-like bodies, which, however, are often so much divided as almost to lose their leafy look. These are known as paraphyllia, and it is thought that, just as the paraphyses help to retain moisture round the flowers (see page 37), so these tiny growths perform a similar function for the stem and leaves. A few, much magnified, taken from two members of the Feather-moss tribe, are given in Plate IV. figs. 20 and 21.

Leaf-cells.-Of late years more and more reliance has been placed upon the size and form of the leaf-cells as a means of differentiating between the various species, and these points, nay, even the varying degrees of thickness of the cell walls, thus become matters which cannot too early claim the patient and careful attention of the student. Needless to say that here the use of a microscope is imperative, for it is only in comparatively few cases that the cells are sufficiently large to be discernible at all, with any degree of precision, by the use of a hand lens alone, while the more minute details would be invisible without a much higher magnification than could be obtained with such means. A few instances must suffice to indicate the general features that call for notice; the finer distinctions can only be appreciated after some considerable acquaintance with the numerous forms has made one more or less familiar with their 
distinctive characteristics. In the lower part of Plate VII. will be found a few typical illustrations of cell-structure, all, it will be observed, drawn with a high magnifying power. Fig. 34 is an instance of some cells from a leaf of one of the Thread-moss (Mnium) family, in which group the leaves are specially large, and the leaf-cells correspondingly conspicuous. Those given at fig. 35 , on the other hand, are small and dot-like; those at fig. 36 are larger, but still more or less rounded; while those at fig. 37 are rectangular, and those at fig. 38 hexagonal. Again, the cells drawn at fig. 39, taken from one of the so-called Fringe-mosses (Rhacomitrium), have a curiously wavy outline, which is specially characteristic of most of the members of this family, and which, as may be naturally supposed, constitutes a very noticeable feature. Fig. 40 represents the long, narrow cells of such mosses as the Feather-mosses (Hypnacea). In this case it will be noticed that the cells are pointed at the ends; in other species which have long cells the ends of the cells are rounded, while in others, again, they are flat. Fig. 41 illustrates the wonderful cell-structure which is so characteristic of the Bog-mosses (Sphagna); here we get two forms of cell, namely, those which are narrow and somewhat opaque, and those which are much larger and transparent, and which generally contain a number of delicate fibres or threads on the cell walls. It is on 
account of the peculiarly open formation of the leaf, which is due to the latter cells, that these plants are able to absorb and to hold a large amount of water, and it is to this fact that they owe their well-known spongy nature. In not a few mosses the form of the cell varies in a very marked manner in different parts of the leaf; this is well shown in figs. 42 and 43 . Fig. 42 gives the cells at the base of the leaf of the Prolonged Feather-moss (Eurhynchium pralongum), which are much enlarged as compared with those of fig. 43, which belong to the upper portion of the leaf. In all these features of leaf-form and cell-structure-features of such minuteness as to be inappreciable by the naked eye-we cannot but be struck again with Nature's all-pervading order; for, so constant are most of these characteristics that the presence or absence of any one or more of them will frequently suffice to settle the name of some doubtful specimen.

Uses of Mosses.-We are so accustomed to find that the various members of the vegetable kingdom serve a useful purpose of some kind, either directly or indirectly, and either to man or to the other animals, that the question not unnaturally suggests itself, "Of what use are mosses?" And to this we are obliged to reply that, to man at all events, they are of very little direct service. The Bog-mosses (Sphagna) are employed by gardeners in the rearing of orchids, 
and some of the larger species of the Feathermosses (Hypnacea) serve as good material for packing objects of a fragile nature; while Gilbert White, in an oft-quoted passage in his "Natural History of Selborne," tells us that, in his day, the long stalks of the Common Hair-moss (Polytrichum commune) were made into besoms, which were handy in the "dusting of beds, curtains, carpets, hangings, etc." We also read that the same moss is used by the Laplanders as a substitute for the ordinary stuffing of mattresses, and that the Esquimaux make their lamp wicks of another species. Again, the growth of the Bogmosses through long ages has been one of the principal means by which peat has been gradually formed, and this has, of course, for long provided a by no means unimportant fuel to man.

It is, however, when we consider mosses as part of the botanical community that we learn the true purpose that they fulfil. And here the humble but most important duty which they perform seems to be in keeping with the unpretentious character of the plants themselves. From their very minuteness, and from the fact that they draw the bulk, if not the whole, of their nutriment from the rain and air, they are of course not only peculiarly fitted to find a foothold in situations where more bulky plants would be unable to establish themselves, but also to live and flourish under conditions which would not, 
in the case of the larger and sturdier forms of the vegetable world, suffice to provide means for keeping body and soul together. We consequently find that where a large surface of barren and rocky soil is exposed, either by the work of man, or, on a larger scale, by some convulsion of nature, some of the first pioneers of vegetable growth upon it will almost certainly be drawn from the moss fraternity. No doubt to the gardener this faculty of being able to start life on very scanty means is often the source of much annoyance, as his gravel paths are frequently rendered unsightly, in his eyes, by the soft covering of green velvet which creeps over them in the least-used corners. But from Nature's own point of view the matter bears an entirely different aspect, for these tiny plants that manage to cling here and there on the bare surface will help to provide a lodgment, first for a little more soil, then for some further green growth, until step by step the ground is prepared for the reception of larger and still larger plants.

I well remember seeing this illustrated in a very small way some time ago on one of my holiday excursions. I was working up a small stream in a wood, examining the rocks and stones and out-of-the-way corners for "treasure," when I came across a moss-grown object, which, from its weight, was evidently not a stone, nor could it, from its yielding nature, be a piece of wood; and 
on closer examination the "subsoil" proved to be nothing more nor less than an old boot, which some thoughtless person had thrown into the stream, where it would have remained an eyesore to any nature-lover who might pass by, had it not been for the bright green covering of tiny leaves, spangled with orange capsules, which had transformed it into an object of beauty: thus exemplifying what has so truly been said, that " mosses, like love, make even the ugliest objects beautiful, for they hide all defects with their own loveliness" (Helen Evelyn Day). 


\section{CHA PTER I I}

\section{LIVERWORTS}

THE Liverworts, or Hepatice, to give them 1 their scientific name, form a small group of plants which come next below the mosses in the scale of botanical life; they stand, as it were, between the mosses on the one hand, and the lichens and fungi on the other, being less highly organised than the former, and somewhat more highly organised than the latter. Their relationship to the mosses is, in many respects, so close, and the structure of the two tribes of plants is so similar, that the student of the one may well include the other in his purview; indeed, so nearly do the two approximate to each other in some respects, that we meet with plants in which it would seem that a comparatively slight variation in some detail of organisation would have sufficed to transfer them to the other side of the dividing line to that on which they have been actually located; whilst in some few members of one or other of the two tribes there are certain small points of form or construction which strikingly resemble some corresponding feature 
generally belonging to plants of the other tribe. From all of which facts we are almost driven to the conclusion that in long past ages of the world's history the connection between them was much closer than it is now. This dovetailing, as we may call it, of the two tribes, forms a very interesting feature in the life-history of the liverworts, and we shall from time to time, as our story is unfolded, come across striking instances of it.

The name "Liverwort" (which is the English equivalent for the botanical form Hepatica) calls for a few words of notice. In the older books it is applied to comparatively few of the plants that we understand by the term now, the distinctive appellation given to most of them being then "Jungermannia." At the present day, however, "Liverwort" has come to be applied to the tribe as a whole, and "Jungermannia" is now only used as the scientific name of one genus alone. The word "Liverwort" comes to us from times when medical science was comparatively in its youth, and when a great many specifics were in vogue which, in the light of our more advanced knowledge, have lost their efficacy. The suffix "wort" is the Saxon equivalent for "plant," so that the word may be written "Liver-plants"; that is, plants which in some way are associated with the liver. The following sentence, taken from the " Encyclopædia Britannica," gives concisely the 
connection supposed to exist between certain of these plants and the part of the human organisation from which they take their distinctive name: "In the dark ages of medicine, when the doctrine of 'signatures' was in fashion, the strongly marked epidermic cells were supposed to resemble the structure of the liver, and the species were esteemed 'a sovran remedy' in liver complaints." Thus, too, in a work entitled "The Complete Herbal," written by Nicholas Culpeper, M.D., and dated "from my house in Spitalfields, next door to the Red Lion, September 5, 1653," and which is stated in the title-page to contain a reference to " upwards of one hundred additional herbs, with the display of their Medicinal and occult Qualities physically applied to the cure of all disorders incident to mankind," we read that the liverwort is "under the dominion Jupiter, and under the sign of Cancer," and that, "it is a singularly good herb for all diseases of the liver, both to cool and cleanse it, and helps the inflammations in any part, and the yellow jaundice likewise." It is, however, from a totally different point of view that $I$ wish to introduce my readers to these interesting little plants. And while I do not propose to give an opinion as to how far certain of them, which are specially alluded to in the passage above quoted, may prove a corrective for the troublesome complaint referred to, yet if an object for country walks, and a never-ending resource for the 
occupation of leisure hours, can exert an influence on bodily and mental well-being - and who will be so bold as to deny that they may?-then, with the herbalist of old, I would recommend this pursuit as a means of adding to health, and consequently to the happiness of life.

Number of Species.-The liverworts are much fewer in number, both as regards genera and species, than the mosses, so that the moss-hunter will not be greatly enlarging his work if he includes them in his field of operations, especially as the two kinds of plant are so constantly found growing in close proximity the one to the other. The most modern catalogue yet published gives between two and three hundred different British species. Though many of these have a fairly wide distribution-some few, in particular, being distinctly common-yet a great many of them are but seldom found, and, in turning over the pages of one of the more recent works on the subject, one cannot but be struck with the comparatively frequent repetition of such phrases as "somewhat rare," or " not common." This fact may, no doubt, to some extent militate against the general attractiveness of the study; but for those who are able, even occasionally, to go farther afield than their own immediate locality - and how many more now, as compared with former days, manage to spend at least a week in the summer or autumn among the woods and the hills-the fact that 
search must be made in out-of-the-way nooks and corners, and that some amount of patience and perseverance must be exercised if a real "find" is to be made, should only prove an additional incentive to the discovery of new habitats and rare species.

General Characteristics.-As in the case of the mosses, so with their near relatives the liverworts, no cut-and-dried scientific definition would serve any useful purpose in a simple work such as the present. A personal acquaintance with a few of the commoner kinds will soon suffice to enable any one to recognise even those that have a strong likeness to mosses, without much difficulty; and, should there at first seem room for doubt as to the nature of any particular plant, a glance through the magnifying-glass will generally serve to dispel it. From the point of view of their external form, liverworts naturally range themselves into two groups, namely, the leafy or foliose plants, and those that are frond-like or frondose. The leafy liverworts often bear a close resemblance at first sight to mosses, consisting as they do of a well-defined stem clothed with leaves; but on a nearer examination there are certain significant features which will soon be recognised as distinctive of the tribe in general. In the first place, the leaves are, as a rule, more delicate and "filmy" in appearance, owing partly to the fact that they are composed of larger cells, and partly 
to the thin walls of the cells themselves. Then, again, the plants very frequently have a markedly flat growth, the leaves being pretty much on the same plane, so to speak; this is a characteristic which is not very often met with in the mosses, though occasionally, as in the Flat Fork-moss (Fissidens) family, to which reference has several times been made, we find a striking instance of it. The shape of the leaves, too, in most liverworts is quite distinct, as a comparison of the drawings in Plate VII. with those in Plate X. will abundantly testify. At the same time there are a few mosses the leaves of which bear some resemblance to those of a liverwort, both as regards form and cell-structure. For instance, the Dotted Thyme Thread-moss (Mnium punctatum, Plate II. fig. 2) has specially large leaf-cells, to which fact it owes its distinctly filmy appearance, while the shape of the leaves approximates somewhat to the general character of the leaves of many liverworts. And the same remarks apply with still greater force to a beautiful large-leaved moss, known as the Shining Hookeria (Pterygophyllum lucens), which may sometimes be found growing in the shadiest parts of a wood, preferably on the banks of a stream, where it may get an abundance of the moisture that it loves so well. These are, however, exceptional cases, and are therefore not likely to cause much difficulty, even to a novice in the study. 
The frond-like form of liverwort, on the other hand, cannot possibly be mistaken for a moss, though plants of this class are sometimes very like certain of the lichens in outward appearance, and are still more liable to be confused with the early stage, or prothallium, of a fern, to which some of them bear a very strong resemblance. In this group the whole plant takes the form of a flat green plate or frond, which grows quite close to the surface of the soil or other substance to which it happens to be attached. Plate VIII. figs. 1 to 16 are all illustrations of leafy liverworts, while figs. 17 to 20 represent frond-like plants. But here we are reminded again of the constantly recurring fact that Nature seldom draws a hardand-fast line; for while in some instances there is no difficulty in saying at sight whether any particular plant belongs to one group or to the other, yet there are a few that are evidently on the border line, and that clearly show how the two forms merge the one into the other.

Habitats.-From what has already been said, it will have been inferred that both mosses and liverworts live in very similar homes, and under much the same conditions. The latter, however, are by no means so cosmopolitan as their relatives, and are certainly much more shy of contamination with smoke; hence it is that if we would make their close acquaintance it becomes necessary to seek them out in localities which are specially 
congenial to them. If mosses are, as a rule, moisture-loving plants, much more may this be said of liverworts; and hence it is that to find them in the greatest luxuriance, and to see them in the full enjoyment of life, we ought to seek them in some of the moister parts of the Lake District or of Wales, or, better still, in the Emerald Isle, the home par excellence of many of the rarer species. In the shade of the woods; on the rocks of a rivulet splashed by the water; on the wet banks of dykes, drains, and ditches; in the shelter of the hedgerows; in the boggy and marshy ground on the borders of some pool or lake; in these and similar localities many kinds may frequently be met with. Others to a large extent confine themselves to the trunks and branches of trees, while not a few of the smaller and more dainty forms are often found growing in close company with mosses, creeping in and out amongst the slender stems and pale, green leaves, and not uncommonly looking very much like fine white thread.

Let us, with the help of Plate VIII., take a glance at some of the commoner kinds, and we shall thus obtain a better idea of their general appearance and structure; and the fact that all the figures in the plate (with the exception of fig. 20, which is about life-size) have been drawn to the same scale, namely, five and a half times larger than the originals, will give some idea of 
the great variety in size that is to be met with in nature. The Square-leaved Liverwort (Chiloscyphus polyanthos, fig. 1), one of the larger forms, is a specially moisture-loving plant, which often grows in great abundance in wet, boggy ground, or in the clear water of some small spring which wells up on the hill-side. Its leaves are somewhat rectangular in outline, but with the angles rounded off. They are pale green in colour; and, being formed of large, thin-walled cells, they have that delicate, filmy appearance which, as already pointed out, is so characteristic of many of the liverworts. The Two-toothed Liverwort (Lophocolea bidentata, fig. 2) is one of the commonest of the tribe. It is by no means particular as to its quarters, and will make itself at home on the hedge bank, on tree trunks, and in other situations, generally, however, seeking a shady position. The name of the plant is, of course, suggested by the shape of the leaf, which is markedly twotoothed, though this form of leaf is by no means restricted to this particular species. In this case, too, the leaf-cells are large and thin-walled, and the plant has a more or less filmy appearance in consequence. The Whitish Liverwort (Diplophyllum albicans, fig. 3) is perhaps the most widely distributed of all the leafy liverworts, growing as it does, often in extensive colonies, on the banks by the roadside, in woods, on rocks, and in fact almost anywhere in the country. Its 
leaves are bi-lobed-that is to say, each leaf consists of two portions or lobes, a smaller and a larger one; a feature which, as we shall find, characterises many individuals of the group. This particular one is easily distinguished owing to the fact that a narrow band of long, pale cells extends up the centre of the leaf, giving the appearance of a somewhat indefinite nerve. I shall have occasion to refer again to this when dealing more in detail with liverwort leaves. At Plate X. fig. 15 is a magnified leaf, the socalled pseudo-nerve being all the more distinct.

The Inflated Liverwort (Jungermannia inflata, Plate VIII. fig. 4) is a small plant that grows very freely on boggy and peaty soil, often forming large, dull, reddish brown tufts of considerable size. Here again the leaves are two-toothed, but each tooth, instead of being pointed, is rounded off at the end. Fig. 5 is a small piece of a tiny plant, the Creeping Liverwort (Lepidozia reptans), which lives on rotting tree trunks, or on the ground, not unfrequently covering it with a thick green carpet, which when examined with the glass is seen to be made up of numberless thread-like stalks matted together, each of them bearing at intervals the minute three- or four-toothed leaves as shown in my illustration. Let us examine a piece of it still more carefully, and we shall find that on the under side of the stem, and growing quite close to it, are a number of still more 
minute leaves of a similar form. These are the so-called stipules, though as they do not seemin any botanical sense at all events-to correspond to the stipules of an ordinary plant, under-leaves would really seem to be the more appropriate term for them. These under-leaves or stipules are characteristic of a good many of the leafy liverworts, and, as may be supposed, their presence or absence constitutes an important feature in the tracking out of any particular individual. There is nothing that corresponds to them in any of the mosses that inhabit this part of the world, though I believe that in a few foreign species similar growths are found.

The student is pretty certain to come across the plant represented at fig. 6 in the early days of his researches into the mysteries of the liverwort world. This is the Tubercled Liverwort (Frullania dilatata), a constant dweller on the bark of trees, its round, overlapping leaves, often a dull purple in colour, clinging tightly to the surface, and hardly looking like living plant. When examined under a low power in the microscope, however, it assumes quite a different appearance, not unfrequently showing most beautiful warm brown tints, varied with shades of green and red. The leaves, again, are bi-lobed, the smaller of the two lobes having a remarkable resemblance to a tiny cap; this will be seen more distinctly by reference to Plate $\mathrm{X}$. fig. 3, where 
some of these leaves are drawn on a large scale. Plate VIII. fig. 7, the Wood Liverwort (Scapania nemorosa), is, as its name implies, an inhabitant of woods and similar places, and is by no means uncommon; its leaves also are bi-lobed, and their margins are fringed with fine hair-like teeth. Fig. 8, the Maidenhair Liverwort (Kantia trichomanis), is a common little plant, which grows on the bare earth, in damp, shady places, often in company with mosses; its leaves are somewhat egg-shaped, the ends, though usually rounded, being occasionally slightly notched. The under-leaves are large and noticeable, and are much rounder in outline than the leaves, and with a much deeper notch at the end, giving them a distinctly two-toothed appearance. A small piece of the stem, with some of the ordinary leaves and also the under-leaves, is delineated, on a larger scale, at Plate $\mathrm{X}$. fig. 32a. The leaves themselves are a delicate pale green in colour, and, the cells being somewhat large, the whole plant has that peculiarly filmy appearance to which reference has already so often been made. The Little-lobed Liverwort (Lejeunea serpyllifolia, fig. 9), doubtless so called from the minute size of the lower lobe of the leaf, is a beautiful little plant, which forms a very attractive object for a microscopic slide, having, when seen against a black background, a particularly bright appearance. It haunts rocks, banks, tree stumps, etc., 
generally in damp and shady corners, and, though by no means widely distributed, is often very abundant in localities which happen to be specially favourable to its development.

The Hair-leaved Liverwort (Blepharostoma trichophyllum, fig. 10) is somewhat rare, though, possibly owing to its minute proportions, frequently overlooked, for to the unassisted eye it simply has the appearance of a piece of fine cotton; and, as it is generally to be found creeping among mosses, a good deal of careful searching is requisite in order to discover it. It would be difficult to imagine anything more beautiful in its way than a frond of this plant in the microscope, with a moderately low-power lens, and a black background, the delicate silver tracery of the stem and its tiny, bristle-like leaves being thrown up in strong relief by contrast with the dark surroundings. The plant given at fig. 11, the Crenulated Liverwort (Jungermannia crenulata), has very markedly round leaves, though why this special name should have been bestowed upon it is difficult to say. It grows in wet, sheltered places, often choosing a heavy clay soil. I have seen the bank by the roadside in one of the Somersetshire combes quite thickly covered for some little distance with matted tufts of its pale green fronds. Under the microscope, or even with a strong magnifying-glass, it may easily be distinguished from all the other round-leaved 
liverworts owing to the presence of a row of large square-shaped cells round the margin of the leaf, which at once strike one as something uncommon.

Fig. 12 is another very small plant (Lejeunea ulicina), which is not often met with, though, again, this may be partly due to its minuteness, and partly to the fact that it grows among mosses, and is thus not easily distinguished. It generally prefers the trunk of a tree for its habitation. The Two-horned Liverwort (Cephalozia bicuspidata, fig. 13) belongs to a family of diminutive plants which usually live on the ground, or creep among the stems and leares of mosses. This one is the commonest, and its long, slender white, thread-like stems may be found creeping on wet clay soil by the roadside, though, owing to its minute size, it will certainly not be discovered without the help of a glass. It affords yet another instance of a plant with two-toothed leaves.

In the Globe-fruited Liverwort (Jungermannia sphcerocarpa, fig. 14) we have another roundleaved plant. This is also a frequent denizen of damp, shady nooks, producing its fruit-which, as indicated by its name, is round, instead of oval, in form-in the early spring. Fig. 15 is a beautiful moisture-loving little plant, which has been named Hutchins' Liverwort (Jubula Hutchinsia), after Miss Hutchins, a famous Irish 
botanist, who first discovered it in the South of Ireland. It also rejoices in very moist surroundings, generally growing on rocks over which the water trickles, or in the splash of some waterfall, and is comparatively rare. I well remember finding it in Devonshire, growing like a weed at the back of a small cascade, in the middle of a dark wood, and shall not easily forget the thrill of pleasure with which I recognised it. The leaves, it will be noticed, are rounded at the end, and bear a few rather large teeth, and the underleaves are very noticeable, occurring at intervals on the lower side of the stem. They are specially distinctive in form, as will be seen from Plate $\mathbf{X}$. fig. 34, where one is given on a larger scale. In the Notch-leaved Liverwort (Jungermannia exsecta, Plate VIII. fig. 16)-an occasional dweller on heaths or in woods-the leaves, which grow closely overlapping each other, are peculiar in form, and the strikingly notched margin has, no doubt, suggested the specific name given to the plant.

Having now made the acquaintance of some typical plants belonging to the leafy order, let us next turn our attention to a few of the frondose group, though it must be at once admitted that these have not the same attractions, either with regard to colour or form, as the various species that we have been considering. Plate VIII. fig. 17 represents a small piece of the Many- 
lobed Liverwort (Aneura multifida), a plant which literally lives in water, generally choosing wet, boggy ground, in woods or on the sides of ditches, for its home. Its fronds are somewhat thick and fleshy, and are pale yellowish-green in colour, turning brown when old. One of the commonest of the frondose plants is the Forked Liverwort (Metzgeria furcata, fig. 18). It constantly spreads its light green fronds on moist banks and rocks, or still more commonly on the trunks of trees, creeping in and out among the cracks and crevices of the bark, and often clinging so tightly that it is a matter of difficulty to dislodge them without cutting away some of the bark as well. Under the microscope numerous short hairs will be noticed, growing on the margins and on the nerve. The Broad-veined Liverwort (Pellia calycina, fig. 19) is also a great lover of moisture, and nothing suits its taste better than the boggy ground bordering some small rivulet, or by the side of a spring. Fig. $20-$ a single frond of the Four-lobed Liverwort (Lunularia cruciata)-has been drawn very nearly the natural size in order to give a better idea of the appearance in the field of a typical frondose plant. It is by no means uncommon, and its small, flat, green fronds have a knack of making their appearance on damp and shady gravel paths, or still more abundantly in the dark corners of a greenhouse, and will even invade the flower-pots themselves, covering 
the surface of the soil with a mass of leathery green substance, which is far from being a welcome sight to the gardener. On looking more closely at one of these fronds, two or three crescent-shaped growths will be observed on its face, and if one of these is examined with a fairly good glass it will reveal itself as a tiny pocket, inside which are a number of very diminutive green bodies; these are small buds or gemma, corresponding to the similar developments with which we met in the mosses, and from which future plants will spring. I shall have something more to say on this head later on.

Life-history.-I propose now to trace the various stages in the life-history of the liverworts, as I have already done with the mosses, and it will in this way be possible to learn more of their distinguishing characteristics than could be done by any mere set of definitions; and incidentally we shall be able to note the special points of resemblance and dissimilarity in the members of the two tribes. And on the threshold of the subject we are met by the fact that the earliest stages of growth in the liverworts are by no means so easily observed as in the case of their more aristocratic connections. And though, at first sight, this may seem strange, yet a little consideration will convince us that, on evolutionary principles, it is what we might expect, if mosses represent the more highly developed community. 
For as we ascend in the scale of life we find that Nature, as a rule, tends to attain her ends by more and more direct methods. At all events experience teaches us that with the liverworts the first results of the germination of the spore vary very considerably in different species. We have seen (p. 30) that with a moss the earliest sign of life is, in the vast majority of cases, the formation of a delicate, thread-like growth or protonema, from which the moss-plant subsequently springs. This kind of intermediate stage is also frequently found in the liverworts; but while it is sometimes represented by a branching thread, like that of a moss, at others it takes the form of a flat, green leafy plate, from one end of which the young plant is eventually evolved, while in many cases no definite intermediate stage at all is appreciable, the plant being gradually developed by cell-formation direct from the spore itself.

I have often looked for some sign of these very early days in the life of a liverwort, but the first indications of growth are generally so minute that it is most difficult, if not well-nigh impossible, to come across them in the field, and so, not long ago, I determined to see what could be done by setting up a kind of miniature nursery garden in this particular department. I accordingly procured some spores of the plant figured at Plate VIII. fig. 1, the Square-leaved Liver- 
wort (Chiloscyphus polyanthos), and also some of one of the larger frondose liverworts, the Large-leaved Liverwort (Pellia epiphylla), which, as we have seen, grows on marshy ground, and in the neighbourhood of streams. These spores were sown on two pieces of sandstone (a bit of broken flower-pot serves the purpose equally well), which were placed under a bell-glass, and kept constantly moist. The experiment did not succeed so well with the first-named species as with the other: but after waiting for nearly seven weeks, I found one day that a thin green film had appeared on the stone on which the spores had been strewn. Under the microscope this proved to consist of numerous extremely small cellular bodies, one of which, highly magnified, is given at Plate IX. fig. 1. Doubtless, in course of time, had I been able to carry the matter so far, these would have developed into plants. The second of my two sowings was more successful, for the spores of the frondose plant ultimately gave rise to a few small flat, brownish-green growths, one of which is drawn, on a somewhat magnified scale, at Plate IX. fig. 1a; this represents the intermediate stage in this species, and from one of the cells at its upper margin a plant would ultimately have sprung.

It is in this matter of the germination of the spores that we seem to come across the first indication of the close relationship that exists 
between the mosses and the liverworts, for in the Bog-mosses (Sphagna) the earliest sign of life does not take the form of the green thread, which in most mosses develops from the spore, but is represented by a small flat plate or frond, closely resembling that which, as just mentioned, is formed from the spores of many liverworts. I may here refer to a curious feature which occurs in young plants of that small family of mosses to which the beautiful Pellucid Four-tooth Moss (Tetraphis pellucida), already alluded to more than once, belongs, and which may possibly have some bearing on the present subject. In these plants the earliest leaves are quite different in form from those which subsequently clothe the stem, and have a considerable resemblance to one of the frondose liverworts, as will be seen by a reference to Plate VI. fig. 19, which represents three which were taken from a plant of the last-named moss. I have often wondered whether these germ-leaves-which, by the way, soon disappear, and are never repeated in the subsequent life of the plant-may form another link, as regards outside form at least, with the faroff past, when the two tribes were more intimately connected than they are at the present day.

The subject of the gradual development of the fully formed plant from these very early beginnings is far too abstruse and difficult to be dealt with in an elementary work such as the 
present; any one who desires to know more on the subject will find it treated in great detail in Hoffmeister's masterly work on the Higher Cryptogamia, translated and published many years ago by the Ray Society, as also in Dr. D. H. Campbell's book on "The Structure and Development of the Mosses and Ferns." Here, however, I must content myself with saying that slowly, but surely, the young plant is evolved, and eventually attains to one of the many forms with which we are familiar, the process in some cases taking a considerable time to complete, though in others the rate of progress is much more rapid. I pass on, therefore, to speak of the flowering part of the plant, or

Inflorescence, the seat of the reproductive organs, from which the future fruit will spring. While this stage of liverwort-growth corresponds, in many respects, to the similar one in a moss's development, there are, nevertheless, certain very pronounced differences in detail between the methods pursued by the two tribes. I have only space for a reference to some of the more important of these.

As in a moss, so with a liverwort, the organs of reproduction are of two kinds, the fertilising organ, and the fruit-bearing organ, each of which calls for a few words of description.

The Fertilising Organs (antheridia) are formed in varying positions on the plant, according to 
different species, in some cases growing close to the fruit-bearing organs, while in others separated from them. Thus, in the frondose liverworts they are often found imbedded in the substance of the frond, their presence being not unfrequently indicated in the microscope by a number of dark, circular markings on the upper face of the frond, which are in fact caused by the small depressions in which they lie, and which are covered over by the delicate skin of the frond. On the other hand, in the well-known Common Liverwort (Marchantia polymorpha)-a plant which grows plentifully in damp and wet situations, for instance on the sides of a well or spring in the wall by the roadside, or the shady corners of a greenhouse, literally covering the rock or earth with its flat green fronds-the reproductive organs are housed in small round discs or receptacles, each at the end of a long stalk, the whole bearing a strong resemblance to a tiny parasol. When produced in considerable numbers, as is frequently the case, the numerous pale green heads springing up from the flat, shining green undergrowth, make a very pretty sight. In the leafy liverworts the fertilising organs frequently arise in the axils of the leaves, and we may sometimes get a glimpse of them in the microscope through their beautiful leafy coverings, as is shown in Plate IX. fig. 2, which represents a small piece of the Round-fruited 
Liverwort (Jungermannia spherocarpa). In some cases they are solitary-that is to say, only one grows in the axil of the leaf-while in others a small group of them will be found collected together under cover of a single leaf.

The fertilising organs, instead of being sausageor cucumber-shaped, as in the mosses, are usually round or oval, as in Plate IX. fig. 6, where I have drawn two, taken from that very common little plant, the Whitish Liverwort (Diplophyllum albicans), the acquaintance of which we have already made. That this little round body is extremely minute may be realised from the fact that those given have been magnified some fiftyone times, and that even then they appear no larger than a small pea.

And here let me pause to point out a very striking resemblance that exists between the general form of the liverwort fertilising organs (antheridia), as above illustrated, and those of certain of the mosses, which seems to indicate another point of contact between the two tribes. We have seen that in the mosses these organs nearly always assume that curious sausage-like shape which has already been referred to several times; in the Bog-mosses (Sphagna), however, they are round, like the similar organs of a liverwort, from which, indeed, it is difficult to distinguish them, as will at once be apparent if reference is made to fig. 20 of Plate IX., where a 


\section{MOSSES AND LIVERWORTS}

fertilising organ (antheridium) of the Blunt-leaved Bog-moss (Sphagnum cymbifolium) has been drawn side by side with one from the Whitish Liverwort (Diplophyllum albicans).

The Fruit-bearing Organ (archegonium) corresponds much more closely in appearance with the same organ in a moss, having a more or less distinct neck, which ends in a round, swollen base. Plate IX. fig. 8 gives a group of three, not quite fully developed, while at fig. 7 is one which has arrived at maturity. Here again it must be borne in mind that my drawings are some fifty-one times larger than the original objects. There is one feature in connection with the position of the fruit-bearing organs in which the liverworts differ very materially from the mosses. We have seen (p. 35) that in the mosses the fruit-bearing organs are generally surrounded by a number of special leaves (the perichotial leaves), which, as a rule, are larger than, and differ in shape from, the ordinary leaves of the plant; these special leaves, in addition to forming a protective covering to the reproductive organs, are of great assistance in retaining round them the water that is so essential if fertilisation is to be effected. In most of the leafy liverworts the fruit-bearing organs (and sometimes the fertilising organs also), instead of being enclosed in these large, protecting leaves, are produced inside a leafy, cup-shaped growth, such as that given at 
Plate IX. fig. 5, taken from the tree-growing plant, the Flat-leaved Liverwort (Radula complanata).

This leafy envelope, or cup, as I may for convenience call it, is known in botanical language as the colesule or perianth.

Its form varies, to some extent, in different species. Thus the one just alluded to is simple and cup-like in appearance; the one drawn at fig. 3 of the same plate is more pear-shaped, and has the mouth much contracted-in this case, moreover, there are a number of small wart-like excrescences on the sides which at once serve to show that it belongs to that common tree-loving plant, the Tubercled Liverwort (Frullania dilatata), already described (p. 111). In some cases, again, the upper edge is strongly toothed, while in others it is so much cut up, as almost to have the appearance of having been slashed by some sharp instrument, and numerous other similar small differences will be found in other species. Although this leafy cup, as already mentioned, always contains within it some of the fruitbearing organs, yet these are not unfrequently formed before the cup, and the latter subsequently grows round them. The cup itself no doubt fulfils the same functions as those served by the perichotial leaves in mosses, namely, to protect the small and delicate reproductive organs, and to retain moisture around them with a view to 
their ultimate fertilisation, so careful do we find that Nature always is to provide for the continuance of the race. In the frondose liverworts the cup, when produced (and it is only in certain of them that it is formed at all), will be found growing on the face of the frond.

In some few of the mosses we meet with something which, in outside form, at all events, is strongly suggestive of this leafy envelope. This fact is well exemplified in fig. 8 of Plate IV., which is a drawing of a fruiting plant of one of our common Bog-mosses, the Spreading-leaved Bog-moss (Sphagnum squarrosum), and shows the curious urn-shaped capsule at the end of a somewhat large fruit-stalk (which, by the way, reminds one much more of the fruit-stalk of a liverwort than that of a moss), surrounded by the large perichœtial leaves, which in this instance have a very distinctly cup-like appearance; indeed, one has only to imagine two or three of these large leaves growing together by their edges in order to realise how close the resemblance is. The same thing is found in the members of that small group of rock-growing mosses, to which, as we have seen, the family name of Andreaa has been given; a portion of one of them is given at Plate VI. fig. 6, and shows the capsule rising from the centre of a cluster of the large sheathing leaves, which again suggest the same idea. 
Fertilisation.-As in the moss tribe, so with the liverworts, the fruit is developed from the fruitbearing organ; but, in order that this may be brought about, fertilisation must first take place, and the steps by which this mysterious process is effected are very similar to those by which a moss plant proceeds at a similar stage of its existence. Several of the fruit-bearing organs (archegonia) may be, and generally are, formed inside a single cup, and though two or three of these may be fertilised, yet one alone will arrive at maturity and produce fruit, the others sooner or later shrivelling up. As the fruit-bearing organ ripens, a tiny passage is formed down its neck, and this leads into a large central cell in the swollen base where a special germ-cell is evolved, from which, when fertilised, the future fruit will spring. As in the case of a moss, so here, the small, round fertilising organ, when ripe, bursts, and sends forth a large number of very minute fertilising bodies (antherozoids). Each of these consists of a spirally coiled thread, furnished at one end with two fine hairs or cilia, which are sometimes longer than the fertilising body itself. By means of these hairs, which vibrate very rapidly, the fertilising body is able to move about in water, and may thus sooner or later find its way to the head of one of the fruit-bearing organs, where, after passing down the tiny passage in the neck, it will fertilise 
the germ-cell (oosphere) in the hollow base, which by this time has increased considerably in size, and completely fills up the large central cavity inside which it was formed. It might seem, at first sight, as though the cup would prove an obstacle to fertilisation, but as a matter of fact this is not so; indeed, fertilisation is sometimes effected when it is but half formed, and when its walls are comparatively low. And even where this is not the case the fertilising body has little or no difficulty in finding its way to the interior.

After fertilisation the spore-vessel or capsule begins to develop inside the swollen base of the fruit-bearing organ, and as it increases in size this swollen base swells more and more, becoming, in course of time, very much enlarged (see Plate IX. fig. 5). This enlarged base of the flower is now known as the veil or calyptra, a term which, it will thus be seen, does not bear precisely the same meaning as it does when used in reference to a moss. There it signifies the upper portion only of the fruit-bearing organ, which was torn off when the young capsule burst through its prison walls (see page 43), and this is carried up on the end of the capsule; while here the term signifies the whole swollen base of the fruit-bearing organ inside which the fruit is formed, and which is never rent into two portions when the capsule makes its way out.

At Plate IX. fig. 9 will be found a drawing of 
the veil of the Tubercled Liverwort (Frullania dilatata); it was cut out of the cup, and inside it, if dissected, would doubtless have been found the young, half-formed capsule, which in a liverwort reaches its full development before forcing its way into the light and air. This small, round ball, then, represents the original swollen base of the fruit-bearing organ, which has become enlarged out of recognition by the gradual increase inside it of the young spore-vessel; at the top of this tiny ball will be seen the remains of what was originally the neck of the organ, and which, having now fulfilled its purpose, has more or less shrivelled up.

As the spore-vessel gets larger and larger, and as the fruit-stalk, at the end of which it is formed, lengthens, considerable pressure is exerted on the walls of the veil, which, after a time, not being able to stretch further, split open, thus allowing the ripe but still closed spore-vessel to make its way out, and eventually to emerge into the light of day at the end of its long fruit-stalk. On examining a colony of liverwort plants in the early spring a number of slender, silky white threads may often catch the eye lying on the ground; these are the long, flexible stalks of the capsules; and if a still closer inspection is made many of these silky threads will be found to be tipped with tiny, black, oval heads-the spore-vessels filled with the ripe spores-which 
glisten among the green leaves like so many diminutive jet beads. A ripe capsule which has thus raised itself out of its sheltering envelope is shown at Plate IX. fig. 10; it was taken from the Two-horned Liverwort (Cephalozia bicuspidata), a delicate little plant, already described, with tiny, transparent two-toothed leaves, a frequent inhabitant of woods and other shady places, growing in tangled masses on the ground, or on rotting tree stumps, or creeping in and out among the smaller growths on some moss-covered bank. Fig. 11 of the same plate represents the cup (colesule) of the Flat-leaved Liverwort (Radula complanata), a small round-leaved plant that grows on the trunks of trees, clinging very closely to the bark, and forming dark green patches, sometimes of considerable size. Here we get a glimpse, through the thin, semi-transparent wall of the cup, of the swollen veil, which has been burst open by the capsule. The latter, too, in this particular instance, has raised itself up, at the end of its long, glossy white stalk, through the wide-open mouth of the cup, and has matured and discharged its burden of spores. Fig. 2 of the Frontispiece is another example.

Plate IX. fig. 4 is an instance of the same kind of thing in one of the frond-like plants, the Forked Liverwort (Metzgeria furcata). Here there is no covering envelope to protect the fruitbearing organ. 
Before leaving the subject of the reproductive organs it should be mentioned that, for purposes of identification, it is frequently very important (as we have already seen is the case with the mosses) to ascertain the relative positions on the plant of the two kinds, or, in other words, to satisfy oneself as to whether the plant is dioicous, autoicous, synoicous, etc. (see page 41). And the sight of the curious leafy cups, which we have been considering, will save considerable trouble. For, as they always contain one or more of the fruit-bearing organs (archegonia), they form a conclusive indication of the presence of these organs.

The Capsule.-The variety of form in the capsule, which is so noticeable a feature in the mosses, and which often constitutes an important item in their identification, is not so strikingly exemplified in the liverworts, and in consequence it will be found that this part of the plant's anatomy is seldom figured in the text-books. Even here, however, there is a certain amount of divergence in many of the species, for while as a rule it may be said that the shape of the capsule is more or less oval, in some instances it is round, while in others it resembles an elongated pod rather than an ordinary capsule.

The escape of the ripe spores from the capsule is generally brought about in a far simpler manner in the liverworts than in the mosses, 
for-except in a few foreign species, where the top of the capsule separates from the rest of the capsule wall-there is nothing to correspond to the lid (operculum), which, as we have seen, usually closes the mouth of a moss capsule (see page 60); nor do we ever find anything in the nature of the beautiful fringe of teeth (peristome) which, in so many mosses, surrounds the mouth of the capsule when the lid has fallen off. As soon as the spores are ripe and ready to begin their life-work they are liberated by the bursting of the capsule. Occasionally it opens irregularly, as in certain species of moss; very rarely the capsule wall divides into two halves, somewhat after the manner of a bean pod. But in by far the greater number of cases it splits, from top to bottom, into four pieces, which remain attached by their lower ends to the top of the fruit-stalk. Plate IX. fig. 12 gives a closed and open capsule of one of the leafy liverworts, and clearly illustrates the general mode of bursting of the capsule wall, as above described. But while in the large majority of cases there would thus seem to be no similarity between the two tribes in this matter of the opening of the capsule, it is just here that we come across what appears to be the most striking link between them.

I have already (p. 64) had occasion to refer, in this connection, to that small group of mosses 
bearing the family name of Andreea, which as a rule inhabit the higher mountains. While from their structure it is evident that these plants must be classed with the mosses, even a slight acquaintance with them cannot fail to draw attention to certain features in which, outwardly at least, they approximate very closely to the liverworts. Look, for instance, at Plate VI. fig. 3, which gives the ripe but closed capsule of one of them, and notice, by comparing it with Plate IX. fig. 12, how forcibly it reminds one of a liverwort capsule at the same stage. Then, too, the fruit-stalk in my drawing is much more like that of a liverwort than a moss, a fact which is still more observable when it is seen in the microscope. But when we learn the manner in which, in these particular mosses, the ripe spores are discharged from the capsule, we cannot, I think, fail to be struck by the likeness to a liverwort, which is here so unmistakable; for in this one family, the capsule, instead of adopting one or other of the methods for the discharge of the spores described at pages 61 to 63 , opens, as we have already learned (see page 64), by means of four slits or cracks in its sides, though these do not extend, as in the liverworts, quite to the top of the capsule. Plate VI. fig. 4 is a drawing of a capsule of the Alpine Andrexa (Andreaa alpina) when dry, and shows the slits in the capsule wall gaping widely open (see also Plate IV.b, figs. 12 and 13). It will be 


\section{MOSSES AND LIVERWORTS}

admitted that we have here a most striking instance of the way in which, at certain points in their life-history, the two tribes of plants dovetail, so to speak, into one another, and the inference seems naturally to suggest itself that, possibly at some time, long ages ago, they may have been still more closely connected.

As there is no lid (operculum) to the liverwort capsule, so, of course, there is no need for anything corresponding to the ring (annulus). And again, the mode in which the capsule opens makes a peristome useless, for the complete rupture of the capsule walls at once liberates the spores. While, therefore, the form of the open capsule, as seen in the microscope, is very beautiful, and its crimson colouring is even richer and more striking than in the majority of moss capsules, the interest attaching to it cannot compare with that which the urn-tipped stalks of the moss tribe always arouse.

Spores and Elaters.-When the contents of a ripe capsule are examined under a high-power lens, another very noticeable difference between the mosses and the liverworts is frequently brought to light. The spores themselves are every whit as small as the spores of a moss, and are commonly round in form, while sometimes, when highly magnified, they are seen to be slightly roughened, like those represented at Plate IX. fig. 15, which, by the way, are unusually large. In the case of 
most liverworts, however, we find mingled with the spores a number of delicate thread-like bodies, sometimes taking the form of exquisite spirals or coils, sometimes plaited into beautiful fairy-like chains. These are known as elaters. They are not invariably present in liverwort capsules, though as a rule they are to be found there, but they are never met with in the mosses. A few of these elaters are given in figs. 15 and 16 of Plate IX., and it will be noticed from these that they not only vary in form, but also in size, for in each case the same scale of magnification has been used. When, moreover, it is borne in mind that each figure is one hundred and forty times larger than the original object, some faint idea may be obtained of the almost unthinkable delicacy of these wonderful structures. The inquiry is naturally raised as to the purpose which is fulfilled by these microscopic bodies, for their almost constant presence seems to imply that they serve some definite end. It is of course extremely difficult, with organisms so minute, to form any definite conclusions, especially as the fact that their action takes place in the interior of the capsule, precludes any direct observation being made, and much has therefore to be left to surmise. Hence one cannot be surprised to find some amount of divergence in the reasons adduced for the presence of the elaters among the spores. Thus, one writer states that, owing to the fact that they are extremely 
hygroscopic (i.e. are easily affected by the presence of water), they help to bring about the bursting of the capsule wall; another believes that their duty consists in loosening the masses of spores at the time when the capsule opens; while others have thought that their sudden uncurling, at the moment when the restraint exerted by the closed capsule wall is removed, helps to scatter the spores. Whichever of these theories is the correct one-and they all, probably, contain some amount of truth-it seems to be generally agreed that the elaters are concerned with the escape of the spores from the capsule. As a rule, they fall with the spores, but occasionally some of them may be found clinging to the empty capsule; thus in fig. 17 of Plate IX., which represents the open capsule of that little tree-loving plant, the Tubercled Liverwort (Frullania dilatata), the curious screw-like elaters are seen standing out from the sides of the capsule in all directions. The fruit of this plant is sometimes, but by no means always, produced in considerable abundance, and when this is the case the small, white, empty capsules are very noticeable, dotted about among the dark green or purple foliage; they form extremely beautiful objects for the microscope, with their dainty fringes of elaters, and my drawing does but scant justice to the charm of the original.

Reproduction otherwise than by Spores.-The 
production of fresh plants is not always effected in what may be called the normal way, namely, by means of flowers, fruit, and spores, though we do not meet with the same wealth of resource in this matter that we did when dealing with the mosses. In many liverworts fresh shoots take the place of the older plants, whilst in not a few reproduction is effected through the agency of very small bud-like bodies or gemma, very similar in appearance to those which are developed by certain of the mosses (p. 86). In the leafy liverworts these buds arise from the margins of the leaves, and plants are not unfrequently found having dark brown patches on the tips of the upper leaves, which are easily seen, even with an ordinary magnifying-glass. These, at first sight, might readily be taken for some obtrusive fungoid growth, but an examination under the microscope will disclose that they consist of considerable numbers of these tiny buds. Plate IX. fig. 13 illustrates this ; it is a drawing of a frond of the Tumid Liverwort (Jungermannia ventricosa), a little pale green plant, with notched leaves, which grows on damp banks, or in boggy places, especially in clay; in fig. 14 of the same plate we have one of these clusters of buds more highly magnified.

In certain of the frondose plants these buds are formed in small cup-like growths on the upper surface of the frond. The diminutive leafy receptacles, with the small green buds lying inside 
them, are very beautiful as seen in the microscope, especially when, as sometimes happens, their margins are cut into sharply pointed teeth. One of them is figured at Plate IX. fig. 18; it is taken from the Common Liverwort (Marchantia polymorpha), to which I have already referred (see p. 122). Most of the buds had already fallen out when my drawing was made, but a few still remain inside, and are shown scattered on the bottom, while three of them, on a larger scale, are given at fig. 19 .

We have now completed the life-story of the liverwort tribe, so far, that is, as it can be told in an introductory sketch such as the present; but before finally parting company with these fascinating little plants it will not be inappropriate to say something, a little more in detail, with regard to their

Leares.-The shapes of the leaves of the leafy liverworts are very distinctive, not to say peculiar, and differ in a marked degree from the general form of moss leaves; how great this difference is, a glance at Plates VII. and X. at once shows. The leaves of mosses, as will be seen from the first-mentioned plate, generally follow in miniature the forms of ordinary leaves much more closely than do those of the liverworts. In the latter plants we frequently meet with more or less rounded or toothed types; these are very 
characteristic of the tribe in general, but they have comparatively few parallels in the foliage of the larger forms of vegetation. Then, too, the finely serrated margin is much less common in the liverworts than it is in the mosses, while the nerve (p. 92), which is present in by far the greater number of moss leaves, is never formed in the leaves of the leafy liverworts, the nearest approach to it, in appearance, being the central line of long, narrow cells in the leaf of the Whitish Liverwort (Diplophyllum albicans, Plate X. fig. 15). But even here there is no true nerve, and little more than a variation in the shape of some of the leaf-cells.

In not a few of the species, moreover, the leaf consists of two parts, or lobes as they are called, an upper (or antical) lobe, and a lower (or postical) one, a feature to which I have already drawn attention. Figs. 3, 10, 12, 15, 26, 33, of Plate X. are illustrations of bi-lobed leaves. In some plants the two lobes closely resemble each other in form, though one is usually much the smaller of the two; in others they are quite dissimilar in appearance, as, for instance, in the Tubercled Liverwort (Frullania dilatata), some leaves of which are given at Plate $\mathrm{X}$. fig. 3 ; here the small under lobe (it has been drawn uppermost in my illustration in order to show its form more clearly) is hollow, and has a distinct likeness to a small hood or cap, while the larger upper lobe 
is round and flat. Or again, look at the leaves drawn at fig. 33 of the same plate, taken from Hutchins' Liverwort (Jubula Hutchinsia); the tiny under lobe on the lower margin of the leaf is reduced to the very smallest dimensions, and is hardly noticeable, even in the microscope, unless attention is directed to it. The only mosses that have anything in the nature of a double part to the leaf are the members of the Flat Fork-moss (Fissidens) family, but this cannot, from a botanical point of view, be said to be in any way analogous to the bi-lobed leaves of the liverworts. In one respect a large number of the leafy liverworts resemble these Flat Fork-mosses (Fissidens), and some few other families of the moss tribe, namely, in their peculiarly flat growth, all the leaves occupying, so to speak, the same plane; this, as already mentioned, is one of their characteristic features, and often helps to single them out, even at first sight.

Leaf-cells.-The cell-structure of the leaf is a matter of no little importance in distinguishing between the various species, hence a few words on the subject may be added, before concluding. Owing to the fact that in liverwort leaves the cell contents are especially dense, and the leaves in consequence very opaque, it is often most difficult to make out the form of the cells, even with the help of a high magnifying power, and it is generally necessary to treat the leaves 
with a strong alkali before examining them. I use a seven-per-cent. solution of liquor potasse for this purpose, though a small piece of ordinary washing soda dissolved in water forms a very good substitute. The best way to proceed is to place a branch of the plant, in a few drops of the solution, on one of the ordinary glass slips used for mounting microscopical slides, to cover this with a cover-glass (also employed in mounting), and, by means of a pair of forceps, to hold the glass over the flame of a spirit-lamp, until the liquid boils; the specimen should then be well washed by boiling it in water, and it will be found that all the details of cellstructure can be plainly seen in the microscope.

There are two points in particular with regard to the structure of the leaves that cannot fail to attract the attention of the student. In the first place he will notice that the leaf-cells of many species are much larger than those of the majority of moss leaves, and, moreover, that the cell-walls are, as a rule, thinner (see Plate $\mathrm{X}$. fig. 37). In a few of the mosses, noticeably in the Thyme Thread-moss (Mnium) family, we meet with similarly large cells, and in these plants may in consequence notice that the leaves are decidedly filmy in appearance. In many of the liverwort leaves too, when examined with a high-power lens, there may be seen small enlargements of the cellwalls-generally somewhat triangular in shapeat the angles of the cells, looking as though they 
were intended to strengthen the point where the two cell-walls meet. These are known as trigones; illustrations of them are given at Plate X. figs. 39 and 41 , in the latter of which they are unusually prominent, the leaf-cells also being specially large. These trigones are not invariably met with in all the species, and consequently their presence or absence in any particular specimen is a matter which will often be very helpful as a means of identification. Trigones are never found in the cells of moss leaves, though occasionally there is a slight thickening of the cell-walls at the angles which strongly reminds one of them; this may be seen in the leaves of some of the Thyme Threadmosses (Mnium). 


\section{CHAPTER III}

\section{BIBLIOGRAPHY}

TT would clearly be going beyond the bounds of a book such as this, were I to attempt to enter upon the subject of the classification of the various species of mosses and liverworts; this part of his subject the student will best master as he gradually becomes acquainted with the plants themselves, and learns to attach to them their specific names, and for such work he will, of necessity, have to consult one or other of the more scientific treatises, where such details are of course fully given. It may, therefore, be of use if I refer very shortly to a few of the books published in England which will best serve his purpose in this and other respects. Until comparatively lately by far the best book, in fact almost the only practical one on the mosses, was Wilson's "Bryologia Britannica," a work which was published in the early part of the nineteenth century, and which long remained the standard treatise on the subject; indeed, even now, one often refers to its clear and helpful descriptions, though its classification has largely been altered by later writers, and the plates have been super- 
seded by the fuller and more accurate delineations of modern times. Moreover, as the book has long been out of print it is difficult to procure, and commands a relatively high price. Dr. Braithwaite's "British Moss Flora" is undoubtedly the largest work on the subject that we possess; it contains descriptions of every species (with the exception of the Sphagna, which are dealt with in a separate volume by the same author), and beautifully executed drawings of all of them in great detail, together with full lists of the synonyms used by various writers. It is, however, somewhat bulky (running to three large volumes), and is too expensive to be within the reach of all classes of students. Fortunately, the would-be bryologist is now provided, at a comparatively low cost, with a book which will admirably serve his purpose, in Mr. H. N. Dixon's "Handbook of the British Mosses." Here he will find a full and lucid description of all the various species (the leading features being italicised), and much practical information regarding them, which will be of the greatest possible assistance. A set of plates from the pencil of the Rev. J. G. Jameson is included, the figures in which are all drawn to a uniform scale, a fact of no little assistance in the diagnosis of specimens. A series of "keys," compiled by Mr. Jameson, is also provided at the beginning of the work, which, to my mind, have done much to diminish 
that feeling of the hopeless difficulty of the subject which, before their appearance, must have deterred many from entering upon the study of these perplexing plants. The price of the work is 18s. 6d. net. "A Synopsis of the British Mosses," by C. P. Hobkirk, contains a concise description of all the British species, and, from its small size, it is very handy for taking on holiday excursions. There are, however, no plates, and from its very conciseness it is not so useful to the beginner as to the more advanced student. The Rev. J. M. Berkeley's "Handbook of British Mosses" is also in its way a very useful book ; it is provided with figures of many of the species, and the introductory chapters on the structure of mosses, etc., are full of interest. Of the smaller works, the "Handbook of Mosses," written by my friend Mr. James E. Bagnall, gives a sketch of the structure, classification, distribution, and habitats of the mosses, and also many useful hints as to their collection and preservation; it is published in the "Young Collector" series of Messrs. Swan Sonnenschein \& Co. Sir Edward Fry's "British Mosses," which has recently been re-issued, is a most attractive book.

'The literature on the subject of the liverworts is even more scanty than that which deals with the mosses. For long, practically the only work was Sir W. J. Hooker's "British Jungermanniæ," published in 1816. A good many years ago an 
"Easy Guide to the Study of the British Hepaticæ," by Dr. M. C. Cooke, appeared in Science Gossip; this gave a very condensed account of the various then known species, and was illustrated by woodcuts, but the nomenclature used is now quite out of date. In 1894" A Handbook of the British Hepaticæ " was written by the same author, containing much fuller details, and illustrated by numerous wood-cuts and seven plates. In 1902 was published "A List, with Descriptive Notes, of all the Species of Hepatics hitherto found in the British Islands," by the Rev. H. W. Lett, which forms a very serviceable book, at the moderate cost of $7 s$. $6 d$., though, unfortunately, it is not illustrated. Shortly after this date, Mr. W. H. Pearson's "Hepaticæ of the British Isles" (which is undoubtedly, at the present time, the standard work on the subject) was completed. In this will be found very full and careful descriptions of all the species, as also most useful observations on their characteristic features, and other points of interest; the whole is completed by a set of beautiful drawings, one full-sized plate being given to each species. The only drawbacks to the work are its bulk and its costliness, the price of an uncoloured copy being something over six pounds. 


\section{CHAPTER IV}

\section{COLLECTION AND PRESERVATION OF SPECIMENS}

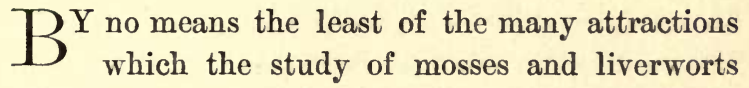
offers to any one in seareh of a hobby, is the ease with which plants may be revived for the purpose of examination; for it matters not how long they may have been gathered, or how dry they have become (and for their proper preservation the drier they are made the better), a few minutes' soaking in hot water (supplemented possibly, in the case of old specimens, by boiling in a test tube for as many seconds) will speedily bring them back, for all practical purposes, to their original freshness, though, needless to say, such drastic treatment cannot renew the tide of life within them. It is, indeed, wonderful to see the effect which such a process will have on what, at first sight, appears to be nothing more than a piece of shrivelled vegetable growth; the small green leaves, which but a moment before were closely curled or wrinkled up, gradually unfold and spread themselves out in the water, until they have resumed their natural appearance, while the 
tiny capsule again expands, and its delicate fringe of teeth opens or closes as it would have done under the influence of a passing shower, when the plant was growing on the shady bank or stonebuilt wall where it had originally made its home. Thus it is that there is no season, year in, year out, and no hour of the day, when the moss-lover cannot find plenty of interesting work to do. In his rambles in the country, whether in the depths of winter, when Nature seems to be asleep, or in the early days of spring, when everything around him speaks of renewed life and of the sunny summer days at hand, right on through the beautiful autumn-time, when the woods are ablaze with marvellous tints of red and yellow, he will always meet with something of interest or delight; while the spoils of his holiday tramps may be examined and mounted on wet days or by the home fireside in the long winter evenings, and will bring back to him many a happy recollection of walks through the lanes and woods, or scrambles up the rugged mountain side, or along the banks of some rippling stream. It will not therefore be out of place if I conclude with a few hints as to the collection and examination of specimens, and the mounting of them as microscopical slides-hints drawn from the stock of practical knowledge gathered from many a leisure hour spent in the study of these charming little plants. And though I shall, for convenience, refer 
to mosses alone, yet all that I have to say will apply also to the liverworts.

Collection and Examination.-The requisites for the collection of mosses are of the simplest description. I have been accustomed, for many years, to use old envelopes for bringing home the specimens gathered on my walks; and, with this object in view, always open any envelopes of a convenient shape that come addressed to me, by cutting them along the narrow end. They then form most convenient pockets in which to put the various plants, and notes can also be made upon them at the time, of the date and locality when and where found, with any other detail likely to be of service, such as the nature of the soil, the altitude, the manner of growth, etc., and memoranda may be added, when the contents of the packet come to be examined, of any special features that call for further consideration. Small squares of stout newspaper will be equally serviceable for collecting purposes, and, indeed, it is well, under any circumstances, to be provided with some of these in which to put up the larger and wetter plants; for, in addition to the fact that they are not serviceable for specimens of any considerable length, the chief drawback to the use of the envelopes is, that any moist substance stored in them for long, is liable to loosen the gum by which their several parts are fastened together. These squares of paper may con- 
veniently be first numbered, and any notes respecting their contents can then be easily made on a separate sheet by reference to the numbers. Let me say here that it is most desirable to cultivate the power of recognising the various species in the field, as far as possible, with no further assistance than may be afforded by a hand magnifying-glass; and with this in view it is very helpful to note, on the envelope or paper, the name that at first sight suggests itself, for such a memorandum is not only useful, when the contents of the packet come to be overhauled, but will enable one to check the correctness of first impressions, and more particularly to find in what direction one may have been led astray. A small satchel in which to carry the spoils of the expedition; a good magnifying-glass for making a rough inspection of any particular gathering, or for exploring the cracks and crannies where treasures are likely to be found; an old knife with which to dislodge the plants from their place of growth, be this rock or tree, hedge bank or wall; a small pair of forceps for similar purposes; and a lead pencil for making notes of "finds,"these constitute the outfit of the moss-hunter. The magnifying-glass should have a fairly large field; and experience leads me to add that it ${ }^{-}$is well to secure it to the coat by a short cord, as otherwise it is certain, sooner or later, to be lost. I always carry a second, and somewhat more 
powerful lens for the purpose of elucidating more minute or doubtful details, and for this latter purpose know of nothing more serviceable than one of Browning's "Platyscopic" lenses, with a magnifying power of ten diameters; this is a beautiful instrument, with an unusually large and flat field for the examination of opaque objects.

It is often impossible, when gathering specimens, to avoid bringing away with them some of the soil in which they are growing; and as this not only adds to the bulk of the parcel, but will also give no little trouble when a microscopic slide has to be mounted, it is always advisable as far as possible, to get rid of it at once, before it has had time to dry and harden. The forceps will prove of considerable service in this operation, though, if a stream should be near at hand, the desired object will be best attained by holding the specimen loosely in the hand, and allowing the current to run through the fingers, and thus to remove the dirt and grit without washing away the plant itself. On reaching home, the envelopes that have been used should be placed in an upright position in a warm room, with the ends opened as widely as possible, so as to admit air; and the paper packets should be unfolded. By this means the specimens will get thoroughly dry before they are put away-a matter of no little moment, seeing that otherwise mould and mildew 
are apt to make their appearance, and to spoil the results of the day's ramble. When all moisture has been thus removed the packets may be stored in some dry and convenient place, out of the reach of insects, until the opportunity offers itself for a more thorough examination of their contents, and in this state they occupy but a small amount of space.

The student will soon find that comparatively few plants can be recognised with any degree of certainty, with no further assistance than that afforded by a pocket magnifying-glass, for the distinctions between most of the various species are generally very minute. Moreover, many of the organs which we have been considering, and much of the structure of the leaves and other parts of the plant, demand a much higher magnifying power for their proper elucidation than can be obtained with the best of glasses, and it is only when they are subjected to the more searching inspection which such an increased magnification gives, that the hidden beauty and wonder of these minute growths are brought to light. A microscope of some kind is thus essential, if the study is to be followed up with any degree of thoroughness; though the nature of this part of the student's outfit becomes, as so often happens with regard to the good things of life, to a large extent a question of ways and means. Much good work has been and may be done with a comparatively inexpen- 
sive instrument, though it is of course true that, within certain limits, the better the implement the better the results to be obtained by its use. At the same time, it should be borne in mind that a microscope is an instrument that consists of many parts, and that divers of these may be added and improved upon from time to time as occasion offers. If possible, it is well to begin with a good microscope stand (i.e. the body without accessories), as this may be made the foundation on which to gradually build up a more or less perfect whole. My own experience would lead me to say that, if the funds will allow, the binocular model is greatly to be preferred to the monocular, if only on account of the saving of strain to the eyes that is thereby effected. Fortunately, in the examination of mosses, the higher powers of magnification are seldom or never requisite, which makes it unnecessary to obtain the more expensive lenses. As a rule, I work with 2 -inch, 1 -inch, and $\frac{1}{2}$-inch objectives, with an occasional recourse to a $\frac{1}{4}$-inch glass when some finer detail of cell-structure has to be elucidated. To these may be added a 3-inch lens, which is especially useful in the exhibition of slides; and in ordering the microscope-stand it should be stipulated that the " racking out" should be sufficient to accommodate so low a power as this, in combination with a triple nose-piece.

In order to prepare specimens for examination or for mounting, some form of dissecting-micro- 


\section{MOSSES AND LIVERWORTS}

scope is a practical necessity. For many years I used a very unpretentious instrument, which even now is not unfrequently brought into requisition. This consists of a magnifying-glass in a light metal frame, at one end of which is a narrow collar, which slips over a screw some two inches long, which is capable of being fixed in an upright position in a small metal stand, and is provided with a nut, so that the lens can be set, in a horizontal position, at any required height. Some such glass and stand can be purchased for a small sum from any microscopical-instrument maker, and not unfrequently the ordinary triple lens, in a horn or tortoise-shell case, forms the magnifying-glass-a convenient arrangement, as it gives varying powers for different kinds of work. Where very small objects have to be dissected it is useful to have a metal carrier, one end of which slips over the upright screw, as above described, and the other is provided with a round aperture sufficiently large to receive one of the high-power lenses, in metal fittings, to be obtained from any of the best makers. Of late I have adopted the more modern binocular dissecting-microscope, which is not only most serviceable in preparing objects for examination, but will also be found invaluable in subsequent mounting operations. Though it is of course much more expensive than the simple apparatus just described, the extra outlay involved is well repaid by the much greater 
ease and precision with which dissecting work can be performed by its aid, and the relief given to the eyes by its use-a matter of no small moment when it is remembered that the dissecting and mounting of specimens frequently involve much close and continuous application. Another simple but convenient instrument for the like purposes is the ordinary watch-maker's glass, set in a deep horn mount, by means of which it can be retained in position in front of the eye, and this is particularly useful in such an operation as the extraction of air-bubbles from a specimen about to be mounted; care must, however, be taken that at the critical moment the muscles round the eye are not relaxed, and the glass precipitated on to the proposed mount!

For soaking plants in hot water, preparatory to dissection or mounting, there is nothing so handy as the small china saucers which are used by artists, and which can be obtained, of various sizes, from any artists' colourman. Dissecting instruments of various forms are sold, but the simplest, and to my mind most effective, implements may be constructed by the student himself at a trifling cost, and with very little trouble. Sail needles and glovers' needles (No. 4) make the most admirable dissecting tools; the former may be procured at an ironmonger's, the latter from a draper. Each kind of needle is not only provided with a good point, but is ground with 
three flat surfaces, thus giving as many cutting edges, which are specially helpful-for instance, in separating the leaves of a plant from the stem or branch. The sail needles, being large and strong, are most useful in the less delicate operations, but they require to be well sharpened on a hone after being mounted; the glovers' needles, which are more serviceable in the finer work, are made with a sufficiently keen edge, but of course need to be sharpened from time to time, as they become blunt from use.

Common lead pencils make extremely convenient handles in which to mount these needles. After being cut into suitable lengths, they should be well soaked in hot water, which melts the glue, and in a short time the pencil may easily be separated into two pieces, and the lead pushed out of the groove in which it lies. The needle should then be laid in this groove, so as to project for three-quarters of an inch or more beyond the end of the wood; a fine pin or needle is run through the eye into the wood, so as to hold the needle in place, and is cut off with a pair of wire nippers, leaving a small length to be forced into the other half of the pencil when put in place. In the case of the glovers' needles, which are much finer than the sail needles, some amount of packing with small chips of wood may be advisable. The other half of the pencil is now glued on to its former position, being pressed down over the end of the 
pin or needle, and, to make the whole more secure, each end is tied round with fine thread or twine in a small groove cut in the wood for the purpose. It is well to remove, as far as possible, all traces of the glue from the outside of the handle by scraping the glued edges when dry, as otherwise it is apt to stick unpleasantly tightly to the lips if held for a moment in the mouth in the hurry of finishing a mount. A few ordinary sewing needles set in cedar penholders are also very useful, and one or two of them should be bent at an angle to the holder, as these are often of service in altering the position of objects under examination after the cover-glass has been put on, and will also be found invaluable for a like purpose in mounting work. In order to bend a needle into almost any form it is only necessary to heat it to a red heat in a spirit-lamp, and then allow it to cool, as this will render the metal soft and pliable; after being bent to the desired shape it should be rehardened by plunging it when red hot into cold water. Two pairs of forceps (one with straight, and the other with curved ends), a pair of small scissors, some small camel-hair brushes, a few glass pipettes, and one or two small lancets will practically complete the list of implements necessary, both for dissecting and mounting; to these must be added a stock of the usual glass slips ( 3 in. by 1 in.) and cover-glasses, procurable at any optician's. While, as a simple matter of appearance, the round cover- 


\section{8 \\ MOSSES AND LIVERWORTS}

glass gives a better finish to a slide, yet the square form is often really preferable, because it allows much more mounting surface, and will thus better accommodate the larger objects; though the very fact of the glass being square makes it a more difficult matter, both to centre it on the glass slip, and also to clean it preparatory to sealing the cell, as the corners are very apt to catch in the handkerchief that is used to wipe off the superfluous mounting material, and in this way a mount may very easily be spoiled. The most useful sizes of cover-glass are $\frac{7}{8}$ in. and $\frac{3}{4}$ in., or $\frac{1}{2}$ in., while, if the specimen should be unusually large, specially cut pieces $\frac{7}{8}$ in. by 2 in. should be procured. Two or three cambric handkerchiefs will be needed, both for washing and drying the instruments after use, and for cleaning the glass slips and cover-glasses, and one should be specially set apart for this latter purpose alone, where cleanliness is of such peculiar moment.

Register of Slides, etc.-Before proceeding to deal more in detail with the subject of mounting objects for the microscope, let me devote a few words to the matter of the storing and registering of specimens and slides, for it is by no means unimportant to adopt some definite system from the outset, on which to work. A cabinet for the slides is, of course, a prime necessity, and it will be a saving in the long-run to get one that will hold a large number, for slides have a wonderful 
tendency to increase far beyond what would, at one time, have seemed to be the utmost possible limit. Although, therefore, to the beginner the idea of having a thousand mounted slides naturally seems a most unlikely consummation, I would recommend him, if he intends to accomplish anything worth the doing, to make timely provision for even such a number as this. The slides should be placed flat in the drawers rather than on their edges; for though the latter position is naturally the more economical in the matter of space occupied, it has two distinct disadvantages, which, to my mind, prohibit its adoption. In the first place, the upright position, together with the slight jar involved in placing the slides in the drawer, has a tendency to gradually detach the cement from the edges of the cells; then, too, it is very difficult to decipher even the numbers on the labels, let alone the names of the plants and other details, while the mount itself is, to all intents, hidden by the neighbouring slide. If, however, the slides lie flat in the drawer they evidently occupy what may be called the most restful position, and moreover the eye can see at a glance all that is to be gathered from the information on the labels; while the objects in the cells are open to view, and may even be examined with a glass without the necessity of removing them from the drawer. In most cabinets a couple of small porcelain tablets are affixed to the outside of each drawer, on which 
a note can be made of the slides within, either by reference to their numbers, or to the names of the genera, according to the system of classification adopted. And this leads me to say that the cabinet may be arranged on one of two methods. Some prefer to divide the drawer-space up according to the different genera, in which case the labels on the slides will contain such details as the name and date and place of gathering. This plan certainly has this advantage, that the keeping of a separate register of slides may be dispensed with, the slides themselves forming their own register ; moreover, from its very nature, it ensures that all the slides representing the various species of a genus are kept side by side. But, on the other hand, it is not nearly so economical of space, and does not so easily lend itself to the duplication of slides as does the arrangement according to numbers. For, though the latter system involves some considerable amount of trouble in the systematic keeping of the necessary registers, yet, as regards economy of space and otherwise, it seems to me to have decided advantages. My plan has been to have one general register of slides, including both mosses and liverworts, in which the various mounts are entered consecutively as they are completed, each one opposite to its own specific number, but without any regard either to the tribe or genus to which each belongs. The book is quarto size, and every page is ruled in four 
columns, headed respectively, "Number," "Date when gathered," "Habitat, etc.," "Remarks." The label on the slide, in addition to briefly recording the name and the place and date of gathering, bears the number corresponding with the entry in the Register.

I have also a copy of the "Census Catalogue of British Mosses" (compiled in 1907, under the auspices of the Moss Exchange Club), which has been interleaved and bound, the numbers of the various species in the Catalogue being repeated on the interleaved pages. Opposite to each number I put the numbers of the slides that I possess of the particular species. Thus, Mnium stellare is numbered 441 in the Catalogue, and against this number I find entered 271, 282, and 1,266 , which gives me the reference to the three slides of this moss in my collection. By the help of the latter register I can always find the slides representing any special moss, and the general Register will give me the details of place and date where and when it was gathered, together with any observations that may have been made with regard to it, as, for instance, my authority for its name. And, as the slides are placed in the drawers in numerical order, the necessity for leaving blank spaces for species not yet acquired does not arise. It is useful to have a third register, ruled with two or three columns to a page, the columns being numbered and named in 
correspondence with the "Census Catalogue," as here can be entered a short note of the plants that are met with in different localities, but which are not mounted. I have yet another Register, which, though by no means a necessity, has nevertheless proved fertile in suggestions; this consists of a small book in which are recorded, opposite to the corresponding numbers of the slides, the media used in mounting and sealing, and the dates when these respective operations were performed, so that, if any particular slide should go wrong-and alas! this will sometimes happen in the best-regulated collection-it is easy to see from this book the general details of both mounting and sealing. Thus a hint may not unfrequently be gathered as to what to avoid in future; and, moreover, a glance at the Register will often tell whether it is advisable to add another coat of varnish round the margins of the cells.

It may be useful to add, in this connection, that dried specimens are best preserved in paper packets, on the outside of which should be noted the name, and date and place of gathering, as also any other information, such as the name of the collector, etc. These packets may conveniently be gummed onto sheets of stout paper, $16 \frac{1}{2}$ in. by 10 in., each one of which bears at its lower lefthand corner the name of the genus and species, and at its upper right-hand corner the corresponding number in the Catalogue. 
Mounting.-Owing to their small size, and to the facility with which their original appearance may be recovered, as already noticed, mosses may be far more satisfactorily preserved than is possible with ordinary plants. The greater number may be readily mounted on the ordinary glass slips as microscopical slides; and not only do these occupy but comparatively small storage space, but the plants themselves will remain, for all practical purposes, as fresh as when they were gathered. I have specimens in my collection now that were thus put up twenty and more years ago, and which have altered wonderfully little in the meantime. The media generally recommended for the mounting of mosses are glycerine, glycerine jelly, Farrant's Solution, and Deane's Gelatine; but, after a fairly long acquaintance with them all, I unhesitatingly prefer glycerine jelly, as giving the best allround results, and I shall therefore chiefly confine myself to a description of the ordinary process of mounting in this material, adding a few words later on as to other media.

The plant to be mounted must first be well soaked in hot water, with a view both to reviving it and to freeing it, as far as possible, from all traces of earth and grit, and from the bubbles of air that are so liable to get entangled among the leaves, or in the empty capsules. Indeed, it is not unfrequently advisable, especially when the 
moss is very dry, or if it is one in which the leaves grow thickly on the stem, to boil it for a minute or so in a test-tube, over a spirit-lamp, so as to aid in expelling the air, or to soak it for some time in water which has been allowed to boil for ten minutes or a quarter of an hour, and which consequently contains comparatively little air. The specimen, while still in the water, must be cleansed, as far as may be, from impurities, and freed from air, by means of a camel's-hair brush and the dissecting-needles. Too much time and attention cannot be given to this somewhat tedious process, as the success of the mount very largely depends upon the thoroughness with which it is effected.

The specimen, when thus sufficiently washed, has still to be subjected to a further preliminary treatment, for if at once immersed in the mounting medium the effect would be to curl up the leaves beyond recognition. A very simple, and in many cases most effective, way of avoiding this is to place it in a teaspoonful of water in which three or four drops of glycerine have been mixed, and then to boil over a spirit-lamp for a few seconds; by this means the glycerine more or less takes the place of the water in the cells, and the leaves may then be safely mounted. In the largercelled and consequently more "filmy" plants, however, this process is not sufficient, and the plant must then be soaked for twenty-four hours in a preparatory mixture composed as follows: 
Water, $1 \frac{1}{2}$ fluid ounces ; rectified spirit, $1 \frac{1}{2}$ ounces ; glycerine, 5 drachms. More often than not, I subject the material for a contemplated mount to both treatments, in order the more effectually to extract the air, the presence of which constitutes the principal difficulty in mounting, and the chief factor in the possible future spoiling of the slide. The small china pans in which moist water-colours are sold will be found most useful for the purpose of soaking the specimen in the preparatory fluid; they are made in two sizes. Failing these, watch-glasses form admirable substitutes. Our plant is now ready to be put into the glycerine jelly, and, necdless to say, this must be melted before it can be used; hence a hotwater bath becomes a necessity. A very simple and inexpensive one can be made of an ordinary glass tumbler, provided with a closely fitting tin lid having a piece cut out of the margin just large enough to admit the neck of a small glass bottle containing the jelly, but not as wide as the projecting lip of the bottle. When the lid is in place, the bottle (which is from time to time replenished from the larger stock-bottle) can thus hang by its lip in the hot water in the tumbler, and the melted jelly is consequently close at hand for use. If the mounting is likely to take long, it is well to wrap a piece of flannel round the tumbler, in order to retain the heat in the water as long as possible. It should be mentioned in 
passing that, whatever pattern of hot-water bath is adopted, it is advisable to put the jelly in actual use into quite a small bottle, as this avoids the evaporation of the water contained in it, which would result if the same jelly were frequently melted. The glass slip to receive the specimen, as also the cover-glass by which it is to be protected, must be thoroughly cleaned before being used; a good plan is, first to rub them over between the finger and thumb with a little acetic acid, in order to remove all grease, and then to well wash them in clean water (hot water is better than cold), drying them with a soft cambric handkerchief, and finally polishing with a washleather. The drying of the cover-glasses is at first a matter of some difficulty, owing to their extreme thinness; but with a little practice the process soon becomes a perfectly easy one, though greater care has to be taken with the square glasses, as the corners are apt to catch in the handkerchief. The slip and glasses should be tilted against something until ready for use, and care must be taken to use the lower faces in mounting, as dust is not so likely to have settled there in the meantime as on the upper sides.

The plant to be mounted is now taken out of the preparatory fluid, and is placed on a glass slip in a little of the fluid, both in order to keep it moist, and to avoid the risk of air making its way in again; it is then subjected to further examina- 
tion under the dissecting-microscope, for the purpose of detecting any lingering air-bubbles or traces of soil. Some of the leaves are carefully dissected away (where necessary, both from stem and branch), and are placed in a small heap by themselves, together with any other part of the plant that may be desired, such as the capsule, peristome teeth, etc., being also kept moist. The glass slip to be used in the mount is next placed upon the flat tin cover of the hot-water bath, and a small pool of the liquid jelly is put upon it by means of a glass pipette, ready for the reception of the specimen, which, after being freed from as much of the preparatory fluid as is possible, without the risk of allowing air to make its way back among the leaves (either by tilting the glass slip on which the specimen has been temporarily placed, or by a judicious use of blotting-paper), is gently lowered into the jelly. While the jelly remains liquid all remaining air-bubbles must be carefully removed with the dissecting-needles, and here the binocular dissecting-microscope will be found invaluable. This operation is often particularly irksome, but it should be remembered that the success of the slide entirely depends upon the care with which it is carried out; for nothing detracts more from the appearance, and only too often from the value of a mount, than the presence of these disfiguring silvery globes of air, lurking among the interlacing leaves, or, perhaps, 
entangled in the teeth of a peristome. Very often, after chasing a number of these bubbles, one sees one of them left, possibly almost hidden by the leaves, or at the bottom of a capsule, where it would seem to be practically powerless for mischief; and one is tempted to let it alone, but experience will sooner or later show that it is a great mistake to do so. I have had many a slide ruined by just such a bubble working its way up to the surface, and this even years after the mounting was done. It is far better to make a rule that, rather than allow a serious blemish of this kind to remain, the slide must be sacrificed, and the mount be recommenced. It will be found advisable in many cases, especially where an object likely to retain air is under treatment, to put it direct from the preparatory fluid into a little liquid jelly on a spare glass slip (I generally use one with a "sunk cell" for this purpose), and then to extract the air before transferring it to the slip on which it is to be mounted. The whole thing thus becomes more or less saturated and covered with the jelly, and the air is not so likely to reappear among the leaves as where the whole process is carried out on one slip. If this course is adopted, a second hot-water bath will be required, in order to prevent the jelly on one slip cooling while the other slip is in course of preparation.

When the specimen is thus in place, immersed in plenty of the liquid jelly, the cover-glass is 
taken up with the pair of curved forceps, and is gently lowered onto the jelly, beginning from the extreme left-hand side, and driving the jelly (and too often, alas! the specimen also) before it, as it is allowed to fall gradually into place. This is a matter of no little delicacy, for if great care is not taken, and especially if sufficient jelly is not used, a large bubble of air will often make its way in at the last moment, and then there is generally nothing for it but to raise the coverglass, and begin over again. It usually happens that the object gets more or less displaced by the putting on of the cover-glass, and requires some adjustment before the jelly is allowed to set. One of the bent dissecting-needles will now be of great service, for a considerable amount of rearrangement can be effected by its means; stray airbubbles, too, may often be thus removed without disturbing the cover-glass. Should the quantity of liquid jelly used not be sufficient to fill the whole space under the cover-glass, a small additional amount must be introduced by means of the pipette, and it is also advisable not only to see that the jelly comes right up to the edge of the cover-glass, but to let some extend beyond, all round the margin of the cell; this provides for shrinkage in the gelatine, which is one of the chief ingredients of the jelly. Two cells may very conveniently be mounted on each slide; for instance, one may contain a small portion of the 
plant, to show the nature of its growth, together with one or two capsules; the other, some leaves (including a few perichotial leaves), and also a portion of the capsule mouth, to give the peristome teeth, and sometimes a piece of the capsule wall showing the stomata.

One word of caution on a small point may be here given, and it will serve to emphasise the need for care and cleanliness even in the most trifling details. It is well, from time to time, to clean out the small glass pipette used for conveying the jelly from the bottle to the glass slip; this may be done by means of a very small piece of sponge tied to the end of a thin strip of wood. I remember being much troubled by the constant appearance of a great number of minute bubbles in the glycerine jelly, which proved to be due to the fact that my pipette had been washed in water which contained some admixture of earthy matter; this had formed a thin film inside the pipette, and some acid quality in the jelly evidently combined with an alkaline substance in this earthy film to form carbonic acid, and so caused the bubbles. In addition to occasionally cleaning the pipette, I always dip it, after finishing a mount, in acetic acid, and also, just before using it again, rinse it out with alcohol. Another small precaution that will still further help to exclude these minute air-bubbles is this. When putting the pipette into the bottle of melted 
jelly, be careful always to keep the finger on the open end of it until the other end has reached the bottom of the bottle. In this way the lower strata of jelly will be tapped, so to speak; and, as the heat naturally causes air-bubbles to rise to the upper surface, these are to a large extent excluded from the pipette.

Our slide may now be removed from the hotwater bath and be allowed to cool, and in a few minutes the jelly will have so far solidified that the mount can be examined under the microscope, when, should any defect be discovered, the jelly must be remelted and the shortcoming be rectified. The final process consists in removing the superfluous jelly from around the cover-glass with a penknife (sloping the blade slightly away from the edge of the glass so as to leave a kind of bevelled edge of jelly all round the glass to allow for expansion and contraction), thoroughly cleaning the slide, and sealing the cover-glass round the edge with some kind of varnish; but it is advisable to let the slide stand in its rough state for two or three months before thus finishing it off, as the jelly is more likely in this time to thoroughly contract and settle down. The cleaning of the slide, preparatory to sealing the cell, is another of those operations which, though somewhat wearisome, yet go far to make or mar a mount; for if anything in the nature of grease is allowed to remain on the glass, the varnish cannot adhere firmly, and 
will sooner or later chip off. A bath of a very dilute solution of hydrochloric acid, which is just slightly acid to the taste, is used by some for completing the cleansing process, but I find that nothing serves better than a cambric handkerchief moistened at the tongue. In sealing the cells, care must be taken not to get the varnish too liquid, as it is then very apt to run too far over the cover-glass; and when this happens, the only way is to clean it off with turpentine, and after a time to reseal. For closing round cells a turntable is, of course, a necessity.

Nothing now remains but to affix the label, and the slide is complete. Before, however, quite leaving the subject of mounting, I propose to add a few observations on the various media used, and cannot do better than begin with

Glycerine Jelly.-The one drawback to this is that it sometimes, and too often from some unknown cause, develops a tendency to liquefy, and this even after the slide has been finished for several years. It is rather a bitter experience, on going to a favourite mount, to find that tiny beads of glycerine have forced their way through the varnish all round the edge of the cover-glass, and that the jelly surrounding the object is becoming fluid. Some years ago I had the misfortune to lose a considerable part of my then small collection of slides in this manner, and since that time have kept a careful record of all my mounts, 
and have also made numerous experiments, with a view to discover some way of obviating such a catastrophe in future. I venture to give here some of the results of these observations and experiments.

In the first place, I have found the following a very good recipe for making glycerine jelly: Take two ounces (by weight) of the best gelatine (that sold by chemists as "invalid" gelatine by preference); soak it in six ounces (also by weight) of water until it swells-this takes about forty minutes; place the vessel containing the gelatine and water (a large-sized jam-pot, provided with a tin lid, answers the purpose admirably) in a saucepan of water, and heat over a slow fire until the gelatine melts, which it will do in about ten minutes. Now let the gelatine cool, and, while it is still liquid, add the white of one egg, and mix well. Replace the vessel in the saucepan (with the lid on), and boil for fifteen minutes, until the gelatine becomes thick with the coagulated albumen; add six ounces (again by weight) of pure glycerine, and twenty-five drops of carbolic acid, and mix well; strain, by means of a funnel and filter-papers, before the fire, and a clear, pale yellow jelly should be the result. The filter-paper requires changing occasionally, as it gets clogged if used for too long.

It will be seen that the above recipe includes a small quantity of carbolic acid ; this, it is needless 
to say, is used as a germ-destroyer. I am inclined to think, however, that owing to the jelly having to be melted by heat, and often remaining in that condition for some considerable time, the carbolic acid is apt to evaporate. On this account I not unfrequently add a very minute quantity of the acid (just as much as will adhere to the end of a thin glass rod drawn to a fine point is quite sufficient) to the pool of liquid jelly on the glass slip before the specimen is put into it. Quite recently, at the suggestion of a friend, I have been using bichloride of mercury (corrosive sublimate) in the same way, and have also substituted twentyfive drops of it for the carbolic acid mentioned in the recipe, when making the jelly. This is, of course, a most powerful germ-destroyer, and it is not liable to evaporate like the carbolic acid; but it must be used with considerable care, as if too large a quantity is introduced into the jelly a slight precipitate of calomel will be the result, and this will give a cloudy appearance to the cell. With a five-per-cent. solution it is sufficient if the tip only of the pointed glass rod is dipped in, and the small amount thus abstracted is transferred to the melted jelly, and quickly mixed with it. I have frequently also used formalin in the cells for a like purpose; but though it has the effect of solidifying the gelatine to such an extent that it is practically impossible to remelt the jelly, yet this is often a distinct disadvantage should it be 
necessary, for any reason, to remount the slide. Another effect which the formalin has on the gelatine is to cause it to shrink considerably, and this may have, and certainly sometimes has, a detrimental effect on the leaves of the plant in the cell. Moreover, it would seem as though the shrinkage of the gelatine, under certain conditions, tended to force out some of the glycerine in the jelly, for recent experiments have shown that, with slides that have been allowed to lie in an unusually cold situation, those in which formalin has been used are the first to develop beads of glycerine round the edge of the cover-glass. While therefore, at first, formalin appeared to offer very decided advantages, a closer acquaintance with it has convinced me that it is not a desirable medium to use in this way.

Although it is often quite impossible to assign any specific reason for a slide having gone wrong, I have found that the observance of the following few simple rules greatly minimises the risks of failure :

1. Care should be taken to free the object, as far as possible, from the preparatory fluid before immersing it in the jelly; hence the advisability of using two quantities of jelly, as before suggested, for this helps to remove all traces of the fluid.

2. No pressure whatever should be applied to the cover-glass when placing it in position on 
the melted jelly; and if its own weight is not sufficient to cause the jelly to flow under the whole of its lower surface, a little more can easily be introduced.

3. While the jelly in the cell is still liquid a small additional quantity should be run all round the outside edge of the cover-glass, in order to allow for the subsequent shrinkage of the gelatine; this may seem a waste of good material, as all this extra amount will have to be removed before the cell is sealed, but the expenditure is really well worth the making.

4. As already mentioned, the superfluous jelly should not be removed, and the cell sealed, for at least two or three months after mounting.

5. The cabinet containing the slide should stand in a room with a fairly equable temperature, and where it will not be exposed to draught.

Glycerine.-Where thin objects, such as moss leaves, are to be mounted, requiring but a slight film of the mounting medium, glycerine itself may be used. A very small quantity, just enough to lie under the cover-glass, should be put on the glass slip ; in this the specimen (prepared as before) is placed, and the cover-glass is lowered onto the glycerine. Any superfluous glycerine must be carefully removed with a slightly wet camel's-hair brush, the whole success of the mount depending upon the thoroughness with which this operation is carried out. Lastly, the 
cell is sealed with Canada balsam, a second and even a third coat being added later in order to guard against the escape of the glycerine. It is much better, with this method of mounting, to use square cover-glasses, as the sealing of a round cell on the turn-table is a matter of considerable difficulty, to say the least. There are certain drawbacks to the employment of glycerine which greatly detract from its usefulness as a mounting medium, though its preserving powers are undeniable. In the first place, the fact that it cannot be used with objects of any thickness, as is possible with glycerine jelly, is a distinct disadvantage. Then, too, if the slide is accidentally jarred, as when it is dropped too suddenly into its place in the cabinet drawer, the Canada balsam with which the cell is sealed is often liable, especially when old, to crack, or chip off; this will cause the glycerine to escape and the mount is spoiled, while with glycerine jelly an additional coat of varnish soon remedies any such defect.

Deane's Gelatine was formerly more frequently used than at present; it has practically been superseded by glycerine jelly, which it closely resembles in composition, honey being substituted for glycerine to prevent the gelatine hardening. I have frequently used it, prepared from the following recipe: Take one ounce (by weight) of gelatine and four of water; soak 
the gelatine in the water until it swells, and then melt the gelatine in the water in the manner before described. Add five ounces (also by weight) of honey, which has been heated to boiling point; boil the mixture, and then allow it to cool. Add the white of one egg, and mix. Boil again for twenty minutes; add half an ounce of rectified spirit in which fifteen drops of carbolic acid or creosote have been mixed, and filter before the fire. In many respects this medium answers very well, but I have found that leaves of a thin and delicate texture are much more likely to curl up, when immersed in it, than they are if glycerine jelly is used. Moreover, it tends to get a much deeper colour with age, and thus to lose some amount of transparency; with high powers, too, a distinctly granular consistency is apparent. Its chief recommendation seems to be that it is not so liable to degenerate as is glycerine jelly; indeed, I have found that slides mounted with it can be exposed to considerable cold for some time before any bad results are produced.

Farrant's Solution, in which gum is one of the chief constituents, has invariably, with me, given unsatisfactory results, as the leaves of the plants always curl up more or less under its influence. This is disappointing, as, owing to the fact that it is used cold, all the apparatus of hot-water bath, etc., which glycerine jelly involves, can be 
dispensed with. The formula which I have adopted is taken from Carpenter's work on the microscope, and runs as follows: Take half an ounce (by weight) of pure gum arabic, and half an ounce (also by weight) of water; dissolve the gum in the water by occasional stirring, but without the application of heat; add a quarter of an ounce of glycerine, and mix well; add half an ounce of arsenious acid (about $\frac{3}{4}$ gr. to $\frac{1}{2} \mathrm{oz}$.) ; filter through fine cambric.

Formalin.-A three-per-cent. solution of formalin makes an extremely serviceable preservative, and I have found this very useful where some of the more delicate and "filmy" leaves form the subject of the mount. It is frequently difficult, in such a case, to use glycerine jelly, as the leaves, on being placed in it, are liable to shrink and twist, thus losing their characteristic shape. No such effect is, however, produced by the use of formalin. The modus operandi (for which I am indebted to the kindness of a friend) is as follows: A shallow cell, of some spirit varnish, must first be made on an ordinary glass slip by means of the turn-table: the Browncement, mentioned on page 183, will answer this purpose. When the cell is quite dry, the slip is again placed on the turn-table; and the top of the cell is ringed round with marine glue dissolved in benzol (see page 182). The formalin solution is next run into the cell from a glass pipette, until it 
stands well above the sides of the cell, and the object is lowered into it. The cover-glass must now be poised between the finger and thumb, and, after being brought as near as possible to the solution without touching it, allowed to fall into place on the top of the cell, driving the superfluous solution out as it settles down. Sometimes, and more particularly if too little of the solution has been used, an air-bubble will make its way in at the last, and then the cover-glass must be quickly raised on one side, and some additional solution be introduced before it is allowed to fall again. 'The cover-glass is now gently pressed down onto the marine glue with a mounting-needle, and after being carefully wiped, so as to free it from all traces of the solution, is ringed round with the marine glue medium, and later on with a spirit varnish. The whole may then be finished off with asphalt varnish. Should it be desired to mount a thicker object, such as a piece of a plant, or some of the larger capsules, a cell of vulcanite must first be attached to the slip by marine glue, and the above steps then followed. The chief advantages attending this method (in addition to the excellent nature of the medium as a preserving agent) are, that no special preparation of the object is necessary, and that the process needs no application of heat. On the other hand, it is subject to all the drawbacks incidental to the use of a liquid medium, which have already been generally re- 


\section{COLLECTION OF SPECIMENS 181}

ferred to. Moreover, there would seem to be a tendency for the sealing medium to "run in," unless much care is taken.

Cements.-The question of the material to be used for sealing the edges of the finished cells is a matter of some importance. I therefore add a few notes giving my experience of the various cements that I have tried. Gold size is so strongly recommended in some of the books that I hesitate to throw any doubt upon its efficacy: my acquaintance with it, however, has not been favourable, for, unless the film of jelly in the cell is very thin, I have almost always found that, sooner or later, the size "runs in," colouring the jelly a much deeper shade than its ordinary tint. Canada balsam is a very good cement, but it is apt to crack and chip off when old ; and the same may be said of Asphalt varnish when prepared in the more usual way by dissolving asphalt in spirits of turpentine. If made, however, according to the recipe given in Davies' "On Mounting Microscopic Objects," I have found it much more reliable. This recipe is as follows: Take $\frac{1}{8}$ drachm of pure indiarubber, $2 \frac{1}{2}$ ounces (fluid) of mineral naphtha, and 1 ounce of pure asphaltum; dissolve the indiarubber in the naphtha, placing the bottle in hot water if necessary for the purpose; then dissolve the asphaltum by the like means.

By far the most useful sealing medium, to my 
mind, is Copal varnish ("picture copal varnish," to give it its full name), to be obtained from any artists' colourman; this may be thinned, when necessary, with a little benzol, which I prefer to turpentine for this purpose. This varnish adheres very closely to the glass, and as it does not dry too hard it does not easily chip off; moreover, it has this further advantage, that if part of the object in the cell has located itself a little too near to the margin of the cover-glass, and is thus covered by the varnish, it may nevertheless be seen through this practically colourless coating.

Where an object of any considerable thickness is mounted, a cement of a thicker consistency is needed, in order to form more of a wall to the sides of the cell, and here nothing could serve the purpose better than Marine glue. The best form in which to apply it is that of a moderately thin solution in benzol, and any one who has had an intimate acquaintance with this most adhesive substance will readily believe that it is far better to purchase the preparation ready-made rather than attempt its manufacture oneself. This is at all times a very safe cement, though, owing partly to its light brown colour, and partly to the fact that it does not dry with a very good surface, it does not impart the same finish to a slide that other sealing media do. These defects can, however, always be remedied by a final coat of asphalt varnish. 


\section{COLLECTION OF SPECIMENS 183}

Ward's "Brown Cement" is also an admirable sealing medium for a like purpose. It can be obtained from any optician. When too thick from age, the cement is easily thinned with methylated spirit; it dries quickly, and in a few hours' time the cell can be finished off, should it be thought advisable, with asphalt varnish. 


\section{CHAPTER V}

\section{CONCLUSION}

$I^{\mathrm{T}}$ now only remains for me to take leave of my readers, and to express the hope that what I have written may be the means of introducing this most fascinating study to some who would not otherwise be aware of its attractions and its many possibilities. I trust that I have been able to show that while it offers healthful and interesting occupation, both for outdoor rambles and for indoor days, its chief recommendation lies in the hidden world of beauty and wonder that it opens up. One cannot help feeling that this side of the matter is sometimes lost sight of ; for, while there is much pleasure to be gained from a search for some uncommon plant, yet the great charm of the pursuit is missed by those who do not feel delight at the sight of even the commonest species, akin to that with which one recognises an old familiar friend. May I venture to add one note of warning which the increase in the number of mossstudents suggests. Delightful as the pursuit is, and numerous as are the opportunities for its exercise, it still has to be borne in mind that even mosses and liverworts have their limits. 
It is truly lamentable to think how quickly some of our rarest flowering plants are becoming exterminated, owing to the thoughtless-to use no stronger term-and lavish way in which they are gathered and uprooted; and it is quite possible, if care and self-restraint are not exercised in time, that a similar fate may some day be in store for our more uncommon mosses and liverworts. One cannot help fearing that those botanists who come after us, and who read our published records of localities once the haunts of plants of especial interest, but whose botanical wealth will then be exhausted, will not have any very kindly feelings for our extravagant and spendthrift ways, and our slight concern for future nature-lovers, whose delight in such things will be as great as, and perhaps greater than, our own.

Let me close with one more quotation from the poet on whose words I have more than once drawn. They will, I hope, sum up the spirit of the story which I have had to tell.

If thou art worn and hard beset

With sorrows that thou wouldst forget,

If thou wouldst learn a lesson that will keep

Thy heart from fainting, and thy soul from sleep,

Go to the woods and hills! No tears

Dim the sweet look that Nature wears.

(LoNGFellow, "Sunrise on the Hills.") 



\section{INDEX TO PLATES}

(The magnifications given are approximate only)

FIG.

\section{Frontispiece}

1. Moss plant, with capsule-Dicranella varia $(\times 10)$.

2. Liverwort, cup and capsule-Lophocolea heterophylla $(\times 10)$.

\section{PLATE I}

MOSS DEVFLOPMENT, AS ILLUSTRATED BY THE PURPLE FORK-MOSS (CERATODON PURPUREUS) FIG.

1. Flower ( $\times 12 \cdot 8)$.

2. Ripe Fertilising Organs (Antheridia) ( $\times 66$ ).

3. Empty Fertilising Organ (Antheridium) $(\times 66)$.

4. Fruit-bearing Organ (Archegonium) $(\times 66)$.

5. Fertilised and unfertilised Fruit-bearing Organs (Archegonia) (× 66).

6. Fertilised Fruit-bearing Organ (Archegonium), more advanced (× 66).

7. Plant with Veil (Calyptra) $(\times 12 \cdot 8)$.

8. Sheath (Vaginula) $(\times 12 \cdot 8)$.

9. Young Capsule and Veil (Calyptra) $(\times 12 \cdot 8)$.

10. Veil (Calyptra) $(\times 12 \cdot 8)$.

11. Capsule and Lid (Operculum) $(\times 12 \cdot 8)$.

12. The Ring (Annulus) $(\times 66)$.

13. The Lid (Operculum) raised by the Ring ( $\times 12 \cdot 8)$.

14. The Lid (Operculum) ( $\times 12 \cdot 8)$.

15. Capsule and Peristome (dry) (x 12.8).

16. Peristome (dry) ( $\times 26)$.

17. Capsule and Peristome (moist) $(\times 12 \cdot 8)$.

18. Peristome (moist) $(\times 26)$.

19. Peristome Teeth ( $\times 91 \cdot 4)$. 


\section{PLATE II \\ MOSSES (PLANTS - $\times$ 5.5)}

Fra.

1. Eurhynchium pumilum.

2. Mnium punctatum.

3. Weisia tenuis.

4. Pottia truncatula.

5. Fissidens taxifolius.

6. Phascum cuspidatum.

7. Eurhynchium rusciforme.

8. Rhabdoweisia denticulat !' "है?

9. Weisia viridula.

10. Tortula muralis.

11. Grimmia maritima.

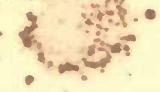

12. Bryum argenteum.

13. Grimmia pulvinata.

14. Campylopus pyriformis.

15. Trichostomum tortuosum.

16. Weisia mucronata.

17. Bryum pallens.

18. Funaria hygrometrica (with veil and young capsule).

19. Eurhynchium rusciforme (pleurocarpous).

\section{PLATE III}

\section{MOSSES (REPRODUCTIVE ORGANS, etc.)}

F⿻.

1. Spores-Mnium hornum ( $\times 51$ ).

2. Protonema and Buds-Ephemerum serratum ( $\times 26)$.

3. Flowers (axillary)-Fissidens bryoides $(\times 6)$.

4. Flower (terminal)-Webera carnea $(\times 6)$.

5. Flowers (axillary)-Eurhynchium pralongum $(\times 6)$.

6. Fruit-bearing Organs-Brachythecium velutinum ( $\times 51)$.

7. Fertilising Organs-Polytrichum commune (x 31).

8. Synoicous inflorescence-Bryum inclinatum $(\times 31)$.

9. Ditto, with Fertilising Organ emitting Fertilising BodiesBryum intermedium ( $\times 51$ ). 
Fia.

10. Veil and young Capsule-Tortula muralis $(\times 6)$.

11. Veil-ditto $(\times 6)$.

12. Ditto-Polytrichum aloides $(\times 6)$.

13. Ditto-Polyirichum nanum $(\times 6)$.

14. Ditto-Orthotrichum rivulare $(\times 6)$.

15. Capsule and Lid-Tortula muralis $(\times 6)$.

15a. Capsule-Leskea polycarpa $(\times 6)$.

16. Cernuous Capsule-Brachythecium velutinum $(\times 6)$.

17. Capsule (round)-Bartramia pomiformis $(\times 6)$.

18. Ditto-Catharinea undulata $(\times 6)$.

19. Capsule-Ceratodon purpurtzs $(\& 6)$.

20. Ditto-Dicranum palustre $(\times 6)$

21. Capsule and Lid, with arcuate Seta-Mnium hornum $(\times 6)$.

22. Lid of Capsule-Mnium hornum ( 6 6).

23. Capsule and Lid-Pottia truncatula $(\times 6)$.

24. Capsule-Phascum cuspidatum $(\times 6)$.

25. Capsule-ditto $(\times 6)$.

26. Lid-Tortula muralis $(\times 6)$.

\section{PLATE IV}

\section{MOSSES (CAPSULES, etc.)}

Fia.

1. Capsule (pear-shaped)-Funaria fascicularis $(\times 6)$.

2. Ditto (strumose)-Ceratodon purpureus $(\times 6)$.

3. Capsule and curved Seta-Funaria hygrometrica $(\times 6)$.

4. Bent Capsule, with smooth Seta-Eurhynchium confertum $(\times 6)$.

5. Portion of smooth Seta-ditto ( $\times 26)$.

6. Bent Capsule with rough Seta-Brachythecium velutinum $(\times 6)$.

7. Portion of rough Seta-ditto $(\times 26)$.

8. Capsule and Perichætial Leaves-Sphagnum squarrosum $(\times 6)$.

9. Capsule and twisted Seta-Tortula subulata $(\times 6)$.

10. Portion of twisted Seta-ditto ( $\times 12$ ).

11. Double Peristome-Brachythecium rutabulum ( $\times 26)$. 
Fia.

12. Capsule with Peristome Teeth erect when dry-Grimmia apocarpa $(\times 26)$.

13. Ribbed Capsule (dry)-Orthotrichum rivulare $(\times 26)$.

14. Striate Capsule (moist)-Orthotrichum saxatile $(\times 12)$.

15. Stem Leaf-Brachythecium rutabulum $(\times 9)$.

16. Branch Leaf-ditto $(\times 9)$.

17. Perichætial Leaf-ditto $(\times 9)$.

18. Leaf-Camptothecium sericium $(\times 9)$.

19. Perichætial Leaf-ditto $(\times 9)$.

20. Paraphyllia-Hylocomium splendens $(\times 26)$.

21. Ditto-Hylocomium umbratum $(\times 26)$.

22. Stoma (immersed)-Orthotrichum anomalum $(\times 140)$.

23. Stoma (superficial)-Orthotrichum affine $(\times 140)$.

24. Papillæ-Tortula laevipila ( $\times 51)$.

25. Ditto-Encalypta streptocarpa $(\times 51)$.

26. Ditto-ditto $(\times 140)$.

\section{PLATE IVa}

Moss CAPSULES, etc.

FIG.

1. Young Capsule and Veil-Encalypta streptocarpa (× 7$)$.

2. Veil-Orthotrichum rivulare $(\times 12 \cdot 8)$.

3. Ditto-Ulota crispa $(\times 12 \cdot 8)$.

4. Immersed Capsule-Grimmia apocarpa (× 12‘8).

5. Ditto, showing Spore-sack-Diphyscium foliosum $(\times 9 \cdot 2)$.

6. Capsule (horizontal position)-Bryum argenteum $(\times 9 \cdot 2)$.

7. Cernuous Capsule-Mnium rostratum ( $\times 9 \cdot 2)$.

8. Pendulous Capsule-Bryum intermedium $(\times 12 \cdot 8)$.

9. Erect Capsule-Ulota crispa $(\times 9 \cdot 2)$.

10. Cylindrical Capsule-Tortula lavipila $(\times 12 \cdot 8)$.

11. Round Capsule-Bartramia pomiformis $(\times 12 \cdot 8)$.

12. Capsule with Apophysis-Splachnum sphoricum ( $\times 9 \cdot 2)$.

13. Ditto, with angular ridges and flat faces-Polytrichum piliferum $(\times 9 \cdot 2)$.

14. Capsule-Buxbaumia aphylla $(\times 5 \cdot 3)$.

15. Ditto, with long, tapering neck-Webera elongata $(\times 12 \cdot 8)$. 


\section{PLATE IVb}

\section{MOSS CAPSULES AND PERISTOMES}

FIG.

1. Sulcate Capsule (dry)-Funaria hygrometrica ( $\times 12 \cdot 8)$.

2. Striate Capsule (dry)-Orthotrichum stramineum $(\times 28 \cdot 4)$.

3. Capsule, with blunt Lid-Funaria ericetorum $(\times 9 \cdot 2)$.

4. Capsule, with apiculate Lid-Bryum pendulum $(\times 9 \cdot 2)$.

5. Capsule, with beaked Lid-Eurhynchium rusciforme $(\times 9 \cdot 2)$.

6. Ditto-Dicranum majus $(\times 9 \cdot 2)$.

7. Cylindrical Lid-Tortula muralis $(\times 9 \cdot 2)$.

8. Capsule, with Peristome of four teeth-Tetraphis Browniana $(\times 12 \cdot 8)$.

9. Capsule and Peristome-Mnium hornum ( $\times 9 \cdot 2)$.

10. Capsule, Peristome, and Tympanum-Catharinea undulata $(\times 9 \cdot 2)$.

11. Capsule with no Lid-Ephemerum serratum ( $\times 28 \cdot 4)$.

12. Capsule, opening by slits in wall (open)-Andreaa petrophila $(\times 28 \cdot 4)$.

13. Ditto (closed)-ditto $(\times 28 \cdot 4)$.

14. Peristome and Tympanum-Catharinea undulata $(\times 26)$.

15. Capsule, with no Peristome-Pottia truncatula $(\times 12 \cdot 8)$.

\section{PLATE V}

\section{MOSSES (PERISTOMES)}

Fia.

1. Peristome (erect)-Mnium hornum $(\times 26)$.

2. Ditto (closed)-Brachythecium velutinum $(\times 26)$.

3. Ditto and Tympanum-Catharinea undulata $(\times 26)$.

4. Peristome and Tympanum-ditto $(\times 26)$.

5. Peristome-Bartramia pomiformis $(\times 26)$.

6. Peristome with recurved teeth-Campylopus pyriformis (× 26).

7. Peristome of four teeth-Tetraphis pellucida $(\times 26)$.

8. Twisted Peristome-Tortula muralis $(\times 26)$.

9. Ditto, partly tubular-Tortula subulata $(\times 26)$.

10. Tympanum-Polytrichum commune $(\times 12)$. 
Fra.

11. Peristome Teeth (double Peristome)-Webera nutans $(\times 51)$.

12. Ditto-Catharinea undulata $(\times 51)$.

13. Ditto-Dicranum scoparium $(\times 51)$.

14. Ditto-Webera nutans $(\times 51)$.

\section{PLATE Va}

\section{MOSS PERISTOMES AND PERISTOME TEETH} Fra.

1. Capsule and twisted Peristome-Barbula unguiculata $(\times 12 \cdot 8)$.

2. Twisted Peristome-ditto $(\times 35 \cdot 5)$.

3. Twisted Peristome, partly tubular-Tortula subulata $\left(\times 20^{\cdot 6}\right)$.

4. Peristome Teeth, recurved when dry-Orthotrichum affine $(\times 35 \cdot 5)$.

5. Mouth of Capsule, with Peristome-Bryum pendulum $(\times 39)$.

6. Peristome Tooth-Bryum inclinatum $(\times 91 \cdot 4)$.

7. Ditto-Mnium hornum $(\times 66)$.

8. Peristome Teeth-Bryum pendulum $(\times 91 \cdot 4)$.

9. Peristome Tooth (cribrose)-Grimmia apocarpa $(\times 91 \cdot 4)$.

10. Double Peristome (dry)-Amblystegium filicinum $(\times 35 \cdot 5)$.

11. Ditto (moist)-Fontinalis antipyretica $(\times 20 \cdot 6)$.

12. Teeth of outer and inner Peristomes-Bryum murale $(\times 66)$.

13. Peristome Tooth (divided)-Dicranum scoparium $(\times 66)$.

\section{PLATE VI}

FIa.

\section{MOSSES (GEMM正, etc.)}

1. Ring-Ceratodon purpureus $(\times 51)$.

2. Lid of Capsule raised by Ring-ditto $(\times 26)$.

3. Capsule splitting into valves (closed)-Andrecea Rothii (× 12).

4. Ditto (open)-Andreaca alpina ( $\times 12)$.

5. Ditto (ditto)-ditto ( $\times 12)$.

6. Capsule and Perichætial Leaves-Andreaa Rothii (× 12).

7. Gemmæ in receptacle at end of stem-Tetraphis pellucida ( $\times 12)$.

8. Gemma-ditto $(\times 51)$.

9. Gemmæ at end of special stalk-Aulacomnium androgynum ( 12 ). 


\section{INDEX TO PLATES}

FIG.

10. Head of Gemmæ-Aulacomnium androgynum $(\times 26)$.

11. Gemmæ-ditto $(\times 51)$.

12. Plant with bulbils in axils of leaves-Webera annotina $(\times 12)$.

13. Bulbils-ditto $(\times 51)$.

14. Gemmæ on leaf-Tortula papillosa $(\times 12)$.

15. Protonemal growths on leaf-Orthotrichum Lyellii ( $\times 12)$.

16. Protonemal growths-ditto ( $\times 51)$.

17. Gemmæ-Tortula papillosa $(\times 51)$.

18. Gemmæ-Tetraphis pellucida $(\times 51)$.

19. Germ Leaves-ditto $(\times 12)$.

20. Smooth Hair-point of Leaf-Tortula muralis $(\times 51)$.

21. Rough ditto-Tortula intermedia ( $\times 51)$.

\section{PLATE VII}

\section{MOSSES (LEAVES AND LEAF-CELLS)}

$(\times 9$, except where otherwise stated)

FIG.

(a) Leaves

1. Leskea polycarpa.

2. Eurhynchium Swartzii.

3. Tortula pusilla.

4. Hypnum stellatum.

5. Andreaea alpina.

6. Polytrichum nanum.

7. Plagiothecium denticulatum.

8. Hypnum Schreberi.

9. Campylopus flexuosus.

10. Amblystegium riparium.

11. Mnium hornum.

12. Hylocomium triquetrum.

13. Amblystegium Sprucei.

14. Tetraphis pellucida.

15. Camptothecium sericium.

16. Bryum caspiticium.

17. Hypnum uncinatum.

18. Brachythecium cirrhosum. 
Fra.

19. Fissidens taxifolius.

20. Dicranella heteromalla.

21. Bryum argenteum.

22. Mnium punctatum.

23. Eurhynchium myosuroides.

24. Thuidium tamariscinum.

25. Tortula muralis.

26. Antitrichia curtipendula.

27. Rhacomitrium canescens.

28. Brachythecium rivulare.

29. Mnium undulatum.

30. Antitrichia curtipendula-end of leaf $(\times 67)$.

31. Grimmia pulvinata.

32. Trichostomum tortuosum.

33. Didymodon flexifolius.

\section{(b) Leaf-cells}

34. Mnium rostratum $(\times 140)$.

35. Zygodon viridissimus $(\times 140)$.

36. Catharinea undulata $(\times 140)$.

37. Barbula rubella $(\times 140)$.

38. Fissidens exilis $(\times 140)$.

39. Rhacomitrium aciculare $(\times 140)$.

40. Brachythecium rutabulum $(\times 140)$.

41. Sphagnum cymbifolium $(\times 140)$.

42. Eurhynchium prolongum-enlarged cells at base of leaf (× 140).

43. Ditto-cells in centre of leaf $(\times 140)$.

\section{PLATE VIII}

\section{LIVERWORTS (PLANTS)}

FT.

\section{$(\times 5.5$ unless otherwise stated)}

1. Chiloscyphus polyanthos.

2. Lophocolea bidentata.

3. Diplophyllum albicans.

4. Jungermannia inflata. 


\section{INDEX TO PLATES}

Fia.

5. Lepidozia reptans.

6. Frullania dilatata.

7. Scapania nemorosa.

8. Kantia trichomanis.

9. Lejeunea serpyllifolia.

10. Blepharostoma trichophyllum.

11. Jungermannia crenulata.

12. Lejeunea ulicina.

13. Cephalozia bicuspidata.

14. Jungermannia sphorocarpa.

15. Jubula Hutchinsia.

16. Jungermannia exsecta.

17. Aneura multifida.

18. Metzgeria furcata.

19. Pellia calycina.

20. Lunularia cruciata (natural size).

\section{PLATE IX}

\section{LIVERWORTS (REPRODUCTIVE ORGANS, etc.)} FIG.

1. First growth from Spore-Chiloscyphus polyanthos $(\times 140)$.

1a. Germ Plant-Pellia epiphylla $(\times 6)$.

2. Inflorescence-Jungermannia spharocarpa $(\times 9)$.

3. Cup-Frullania dilatata $(\times 9)$.

4. Veil-Metzgeria furcata $(\times 9)$.

5. Cup and Fertilised Fruit-bearing Organ-Radula complanata $(\times 9)$.

6. Fertilising Organs-Diplophyllum albicans $(\times 51)$.

7. Fruit-bearing Organ-ditto $(\times 51)$.

8. Fruit-bearing Organs (young)-ditto $(\times 51)$.

9. Veil-Frullania dilatata $(\times 26)$.

10. Ripe Capsule and Cup-Cephalozia biscupidata $(\times 12)$.

11. Cup, ruptured Veil, and Capsule-Radula complanata $(\times 12)$.

12. Capsules-Lophocolea cuspidata $(\times 12)$.

13. Gemmæ on leaf-Jungermannia ventricosa $(\times 12)$.

14. Head of Gemmæ-ditto ( $\times 51)$. 


\section{INDEX TO PLATES}

FIG.

15. Spores and Elaters-Fossombronia cristata $(\times 140)$.

16. Elaters-Frullania germana $(\times 140)$.

17. Elaters adhering to empty Capsule-Frullania dilatata $(\times 26)$. 18. Receptacle for Gemmæ on frondose plant-Marchantia polymorpha $(\times 12)$.

19. Gemmæ-ditto $(\times 12)$.

20. Fertilising Organ (a) of Liverwort (Diplophyllum albicans), and $(b)$ of Moss (Sphagnum cymbifolium) $(\times 26)$.

\section{PLATE $\mathrm{X}$}

\section{LIVERWORTS (LFAVES, UNDER-LEAVES, AND LEAF-CELLS)}

( $\times 9$ unless otherwise stated)

Fia.

(a) Leaves

1. Lophocolea cuspidata.

2. Radula aquilegia.

3. Frullania dilatata.

4. Mastigophora Woodsii.

5. Lophocolea cuspidata-(Under-leaf).

6. Lepidozia setacea.

7. Cephalozia bicuspidata.

8. Lophocolea heteromalla.

9. Ditto (Under-leaf).

10. Lejeunea serpyllifolia.

11. Marsupella emarginata.

12. Scapania nemorosa.

13. Aplozia lanceolata.

14. Plagiochila asplenioides.

15. Diplophyllum albicans.

16. Nardia compressa.

17. Herberta adunca.

18. Trichocolea tomentella.

19. Bazzania tricrenata.

20. Ditto (Under-leaf).

21. Blepharostoma trichophyllum. 
FIG.

22. Jungermannia inflata.

23. Nardia scalaris.

24. Lepidozia reptans.

25. Fossombronia pusilla.

26. Frullania tamarisci.

27. Ditto (Under-leaf).

28. Kantia trichomanis.

29. Ditto (Under-leaves).

30. Scapania curta.

31. Lejeunea ulicina.

32. Lophocolea cuspidata-(Leaves and Under-leaves).

32a. Kantia trichomanis-(ditto).

33. Jubula Hutchinsice (ditto).

34. Ditto (Under-leaves).

35. Jungermannia quinquedentata.

36. Radula complanata.

\section{(b) Leaf-cells}

37. Lophocolea cuspidata $(\times 140)$.

38. Scapania curta $(\times 140)$.

39. Nardia sphacelata $(\times 140)$.

40. Aplozia lanceolata ( $\times 140)$.

41. Mylia anomala $(\times 140)$.

42. Cephalozia bicuspidata (× 140). 


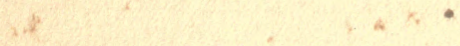




\section{GLOSSARY OF TERMS USED}

- Acrocarpous, where the fruit or spore-vessel is produced at the end of the stem.

- Annulus, the ring of special cells round the mouth of the capsule, just under the lid, the unrolling of which loosens or throws off the lid (p. 61).

- Antheridium, the fertilising organ which contains the fertilising bodies (or antherozoids).

Antherozoids, the minute, spiral, thread-like bodies contained in the fertilising organ (or antheridium), by means of which the fruit-bearing organ (or archegonium) is fertilised (pp. $39,127)$.

Antical, the upper portion (or lobe) of the leaves of certain liverworts (p. 139).

Apiculate, having a small pointed end. Apophysis, of certain moss capsules; a swelling of the fruitstalk where it joins the capsule (p. 52).

- Archegonium, the fruit-bearing organ from which the sporevessel is developed (pp. 38, 124).

- Autoicous, when both fertilising and fruit-bearing organs are formed on the same plant, but are separated from one another. $A x i l$, the angle or space between a leaf and the stem or branch on which it grows.

Axillary, situate in an axil.

Bi-lobed, consisting of two portions or lobes; of certain liverwort leaves (pp. 110, 139).

Bulbil, a very small bulb-like body, from which one or more plants may be developed (p. 89). 
- Calyptra. In mosses, the upper portion of the fruit-bearing organ which has been torn off by the upward growth of the capsule (p. 43). In liverworts, the swollen base of the fruit-bearing organ, inside which the capsule is formed (p. 128).

Capsule, the spore-vessel or fruit.

Cernuous, drooping ; of the capsule, where it is slightly inclined from the line of growth of the fruit-stalk.

Chlorophyll, the minute green grains of colouring matter contained in the leaf-cells.

- Cilia, extremely delicate hair-like growths (by means of which the antherozoids move about in water) (pp. 40, 127).

Colesule, the leafy cup or envelope borne by most of the leafy liverworts, inside which the fruit-bearing, and sometimes the fertilising organs also, are produced (p. 124).

Columella, the small rod or column which occupies the center of the capsule of mosses, and round which the spores are formed.

Cribrose, of the peristome; where the teeth are pierced with minute holes (Plate V.a, fig. 9).

Cryptogams, "flowerless" plants, i.e. not possessing stamens, pistils, and true seeds.

Cup, see Colesule.

Decurrent, when the base of the blade or lamina of the leaf is continued down the stem.

- Dioicous, when the fertilising organs and the fruit-bearing organs are produced on distinct and separate plants.

< Elaters, extremely delicate spiral or chain-like bodies found mingled with the spores of most liverworts, and believed to be connected with the dispersal of the spores (p. 135). Excurrent, of the nerve of the leaf when extended beyond the lamina.

Exserted, where the capsule is lifted up by the fruit-stalk above the surrounding leaves. 


\section{GLOSSARY OF TERMS USED 201}

Fertilising organ, see Antheridium.

Foliose, leaf-bearing; of certain liverworts which bear leaves,

as distinguished from the frondose plants.

Frondose, frond-like, i.e. taking the form of a flat green plate; of certain liverworts.

Fruit-bearing organ, see Archegonium.

- Gemma (Latin, gemma, a bud), small bud-like bodies on the plant, from which fresh plants may spring (pp. 86, 117, 137). Germ-cell, see Oosphere.

- Guard-cells, the crescent-like cells which surround the pores, (or stomata) on the capsules of certain mosses (p. 55).

Immersed, covered; of the capsule, when it is covered by the surrounding (perichrtial) leaves (p. 54); of the stomata, when the guard-cells are situate below the surface of the capsule wall (p. 56).

Inclined, of the capsule, when it is slightly bent at an angle to the fruit-stalk.

Involute, rolled inwards; of the margin of certain leaves (p. 18).

Lamina, the blade of the leaf, as distinguished from the nerve. Lid, see Operculum.

Mitriform, shaped like a bishop's mitre; of the veil (or calyptra).

- Monoicous, the equivalent of Autoicous.

Neck, the lower end of the capsule, where it joins the stalk.

Nerve, the central strand running up the middle of the leaf-

blade of most mosses, corresponding to the mid-rib in the leaf of a "flowering plant."

Oosphere, the special cell in the base of the fruit-bearing organ from which, when fertilised, the capsule is developed (p. 38). - Operculum, the lid of the moss capsule (p. 60). 
Papilla, minute excrescences on the cell-walls.

Papillose, having a roughened appearance, owing to the presence of papillæ.

Paraphyllia, small leafy bodies produced among the leaves of certain mosses (p. 94).

Paraphyses, minute thread-like bodies which accompany the reproductive organs of mosses (p. 37).

Paroicous, where both fertilising and fruit-bearing organs are produced in the same flower, but in distinct groups.

Pendulous, hanging down; of the capsule, when the fruit-stalk bends round at its upper end (Plate III. fig. 21).

Perianth, another name for the cup-like envelope (or colesule) which in certain liverworts encloses the fruit-bearing and sometimes the fertilising organs.

Perichotial leaves, the special leaves which surround the fruitbearing organs.

Peristome, the fringe of teeth (or hairs) which surrounds the mouth of the capsule of a moss (p. 68).

Phanerogams, "flowering" plants, having stamens, pistils, and seeds.

Pleurocarpous, where the fruit is produced at the side of the stem or branch.

Postical, the lower portion (or lobe) of the leaves of certain liverworts (p. 139).

Protonema, the first growth from the spore; in mosses generally taking the form of delicate branching threads (p. 30), though sometimes a flat green plate (p. 120).

Pyriform, pear-shaped.

Ring, see Annulus.

Secund, of the leaves, when all turned to one side. Seta, the stalk of the fruit or capsule.

Sheath, the lower portion of the fruit-bearing organ in mosses (surrounding the base of the fruit-stalk), which is left behind when the veil is formed (Plate I. fig. 8). Spathulate, spoon-shaped. 


\section{GLOSSARY OF TERMS USED}

Spore-sack, the portion of the interior of the capsule in which the spores are formed.

Spores, extremely minute round bodies produced in the capsule, and from which future plants are developed.

Squarrose, spreading out; of the leaves when standing out from the stem.

Stipules, see Under-leaves.

Stomata, small pores or openings in the capsule walls of certain mosses (p. 55).

Strumose (Latin struma, a wen) ; of the capsule of some mosses, which have a small swelling at the base (Plate IV. fig. 2). Sulcate, of the capsule wall, when marked with furrows. Superficial, of the pores (or stomata), when the guard-cells are situate on the surface of the capsule wall (Plate IV. fig. 23). Synoicous, when the fertilising and fruit-bearing organs grow intermingled.

Trigones, thickenings at the angles of the cell-walls of the leaves of certain liverworts, generally triangular in form (p. 142).

Tympanum, the small round membrane (the top of the columella) which closes the mouth of the capsule in certain mosses (p. 75).

Under-leaves, small leaf-like growths on the under side of the stem in certain liverworts.

Vaginula, see Sheath.

Veil, see Calyptra. 



\section{N D E X}

A

Acetic acid, for cleaning coverglasses, etc., 166

Acrocarpous mosses, 58

Air, removal of, in mounting, 163 , $164,166,167,168$

Andrecea, 64

- family, mode of opening of capsules of, 64, 133

-alpina, 65, 133

- Rothii, 64

Andreæa, Alpine, 65, 133

- Black Falcate, 64

Aneura multifida, 116

Annulus. See Ring.

Anomodon, Tall, 24

Anomodon viticulosus, 24

Antheridium. See Fertilising

Organ.

Antherozoid (liverworts), 127

- (mosses), 39

Antitrichia curtipendula, 93

Apophysis, 52

"Apple-moss," 48

Apple-moss, Common, 48, 72

- Fountain, 22

- Eder's, 24

Archegonium. See Fruit-bearing organ.

Asphalt varnish, for sealing cells, 181

- - recipe for, 181

Aulacomnium androgynum, 87

Autoicous plants, 41
B

Barbula unguiculata, 76

Bartramia OEderi, 24

- pomiformis, 48, 72

Beardless-moss, Slender, 15

Bibliography, 143

Bichloride of mercury, use of, in mounting, 174

Bi-lobed leaves (liverworts), 110, 139

Blepharostoma trichophyllum, 113

Bog-dwellers (mosses), 21

Bog-moss, Blunt-leaved, 21

- Spreading-leaved, 126

Bog-mosses, 21

- earliest stages of, resembling those of liverworts, 120

- fertilising organs of, 123

- leaf-cells, 96

- reproductive organs of, resembling those of liverworts, 123

Brachythecium rutabulum, 36, 92

- velutinum, 38, 47, 57, 69

Bristle-moss, Frizzled, 86, 88

- Lyell's, 89

- River, 45, 53

- Wood, 56, 80

" Bristle-mosses," 22

"Brown cement" for sealing cells, 183

Bryum argenteum, 17

- inclinatum, 42

- intermedium, 40

- murale, 79 
Bryum pallens, 25

- pendulum, 73

Bulbils, 89, 90

Buxbaumia axhylla, 51

Buxbaumia, Leafless, 51

C

Cabinet for slides, 158

Calcareous soils, mosses of, 23

Calyptra. See Veil.

Camptothecium sericium, 36

Campylopus pyriformis, 20, 69

Canada balsam, use of, for sealing cells, 181

Capsule (liverworts), 129, 131

- - opening of, similarity to certain mosses, 133

- - rupture of, 132

- (mosses), 46-55

- exserted, 54

- - furrowed, 53

- - immersed, 54

- stomata on, 55

- - variations in form of, 46-54

Carbolic acid, use of in mounting, 173

Catharinea undulata, 12, 48, 74, 78

Cements for sealing cells, 181

Cephalozia bicuspidata, 114, 130

Ceratodon purpureus, 20, 47, 52, 61,82

Cernuous capsule, 47, 57

Chiloscyphus polyanthos, 109, 119

Cilia, 40

Cleaning cover-glasses, etc., 166

- slides for sealing, 171

Club-moss, 7

Colesule. See Cup.

Columella, 75

Commons, mosses of, 19

Copal varnish, use of, for sealing cells, 182
Cord-moss, Common, 20, 52, 57

- Fallow-field, 50

Cover-glasses, shapes and sizes of, 157,158

- cleaning of, 166

Cribrose peristome teeth, 79

Culpeper's “ Herbal," quotation from, 103

Cup (liverworts), 125

- - forms of, 125

- - resemblance to in certain mosses, 126 .

Cup-moss, 7

D

Deane's gelatine, mounting in, 177

- - recipe for, 177

Decurrent leaves, 94

Dicranoweisia cirrata, 22

Dicranum palustre, 49

- scoparium, 13, 78

Didymodon, Bent-leaved, 23

Didymodon flexuosus, 23

Dioicous plants, 41

Diplophyllum albicans, 109, 123, 139

Dissecting microscope, 153

- needles, 155

Drawings, remarks as to, 5

Dried specimens, 162

\section{E}

Early stages (liverworts), 117

- (mosses), 30

Earth-moss, Pointed, 19, 50, 65

- Serrated, 19, 30, 64

Elaters, 134

- supposed action of, 135

Encalypta streptocarpa, 94

Envelopes for collecting specimens, 149

Ephemerum serratum, 19, 30, 64 
Eurhynchium proelongum, 35, 97 - pumilum, 11

- rusciforme, 11

Excurrent nerve, 92

Exserted capsules, 54

Extinguisher-moss, Spiral-fruited, 94

\section{F}

Fallow fields, mosses of, 19

Farrant's solution, use of, for mounting, 178

- recipe for, 179

Feather-moss, Common Roughstalked, 36, 92

- Cypress-leaved, 23

-Dwarf, 11

- Long-beaked Water, 11

- Pointed Bog, 21

- Prolonged, 35, 97

- Sharp Flat-leaved, 13

- Tamarisk, 13

- Velvet, 47, 57, 69

- Wood, 13

"Feather-mosses," 11, 60

Fertilisation (liverworts), 127

-(mosses), 39, 42, 66

Fertilising-organs (liverworts), 121123 ,

- (mosses), 37, 39

Fissidens family. See "Flat Fork-mosses,",

- bryoides, 34

- taxifolius, 24

Flat Fork-moss, Common, 34

- Yew-leaved, 24

"Flat Fork-mosses," 24, 140

"Flowerless"? and "flowering" plants, 29, 66

Flowers (liverworts), 121

- - resembling those of bog. mosses, 123

- (mosses), 32, 39
Flowers (mosses), leaves surrounding, 35

- - position on plant, 33

Foliose plants (liverworts), 105, 109

Fontinalis antipyretica, 71

Fork-moss, Broom, 13, 78

- Marsh, 49

- Purple, 20, 47, 52, 61, 82

Formalin, solution of, for mounting, 179

- use of with glycerine-jelly in mounting, 174

Four-tooth Moss, Pellucid, 70, 86. 89,120

Fringe-mosses, leaf-cells of, 96

Frondose plants (liverworts), 107, 115

Fruit, position of, in mosses, 58 Fruit-bearing organ (liverworts), 124

- (mosses), 38

Fruit-stalk (liverworts), 129

- (mosses), 56-58

Frullania dilatata, 111, 125, 129, 136, 139

Funaria fascicularis, 50

- hygrometrica, 20, 52, 57

Furrowed capsules (mosses), 53

\section{G}

Gather mosses, when to, 26

Gemmæ (liverworts), 137

- (mosses), 86

- growth of, 88

Germ-cell, 127

Germ-leaves (moss) resembling liverwort growth, 120

Glycerine as mounting medium, 176

- use of, in preparing specimens, 164 
Glycerine-jelly as mounting medium, 163, 172

- experiments with, 173

- recipe for, 173

- rules for use of, 175

Gold-size, for sealing cells, 181

Grimmia apocarpa, 78, 79

- maritima, 25

- pulvinata, 16, 93

Grimmia, Grey-cushioned, 16, 93

- Seaside Sessile, 25

- Sessile, 78, 79

Grow mosses, how to, 31

- liverworts, how to, 118

Guard-cells, 55

\section{H}

Habitats (liverworts), 107

- (mosses), 9

Hair-moss, Aloe-leaved, 44

- Common, 74, 75, 98

-Wavy-leaved, 12, 48, 74, 78

"Hair-mosses," 20, 33

- capsules of, 54

- flowers of, 33, 41

Hair-points of leaves, 93

Handles for dissecting-needles, 156

Heaths and commons, mosses of, 19

Hedgerows, mosses of, 18

Hookeria, Shining, 106

Hot-water bath, 165

- reviving and cleaning specimens with, 147, 155, 163

Hypпасеа, 11

Hypnum cupressiforme, 23

- cuspidatum, 21

\section{I}

Immersed capsules, 54

Implements for collection and examination of specimens, 149,155
Inflorescence (liverworts), 121

- (mosses), 32

\section{J}

Jubula Hutchinsa, 114, 140

" Jungermannia," use of, 102

Jungermannia crenulata, 113

- exsecta, 115

- inflata, 110

- sphcerocarpa, 114, 123

- ventricosa, 137

K

Kantia trichomanis, 112

L

Leaf-cells (liverworts), 140

- - treatment of leaves to show, 140

- (mosses), 95

- — forms of, 95

Leaves (liverworts), 138

- (mosses), 90

- - from branch and stem, 92

- - papillose, $13,88,94$

- - perichætial, 35, 92, 124

Lejeunea serpyllifolia, 112

- ulicina, 114

Lepidozia reptans, 110

Lid (mosses), 60

- - raised by the ring, 62

Life-history (liverworts), 117

- (mosses), 27, 81

Liverwort, Broad-veined, 116

$\rightarrow$ Common, 122, 138

- Creeping, 110

- Crenulated, 113

- Flat-leaved, 125, 130

- Forked, 116, 130

- Four-lobed, 116 
Liverwort, Globe-fruited, 114

- Hair-leaved, 113

- Hutchins', 114, 140

- Inflated, 110

- Large-leaved, 119

- Little-lobed, 112

- Maidenhair, 112

- Many-lobed, 116

- Notch-leaved, 115

- Round-fruited, 114, 122

- Square-leaved, 109, 118

- Tubercled, 111, 125, 129, 136, 139

- Tumid, 137

- Two-horned, 114, 130

- Two-toothed, 109

- Whitish, 109, 123, 139

- Wood, 112

Liverworts, bi-lobed leaves of certain, 110, 139

- derivation of name, 102

- earliest stages of growth of, 117

- fertilisation, 127

- foliose and frondose, 105

— frondose, 107, 115

- general characteristics of, 105

- habitats of, 107

- how to grow, 118

- illustrative plants, 108

- number of species, 104

- relationship to mosses, 101

- reproductive organs of, 121

- spores of, 134

Lophocolea bidentata, 109

Lunularia cruciata, 116

\section{M}

Marchantia polymorpha, 122, 138

Marine glue, for sealing cells, 182

Marsh-dwellers (mosses), 21

Metzgeria furcata, 116, 130
Microscope, necessity for, 152

- dissecting, 153

- lenses used, 153

Mnium hornum, 31, 49, 60, 69, 78

- punctatum, 12, 106

- stellare, 24

Monoicous plants, 41

Mosses, acrocarpous, 58

- earliest stages, 30

- fertilisation, $39,42,66$

- flowers, 32

- habitats, 9

- how to grow, 31

- illustrative plants, 11-25

- number of species, 7

- pleurocarpous, 58

- reproductive organs, 36,39

- spores, 28

- times for gathering, 26

- uses of, 97

Mounting, instruments for, 155

- media, 163, 172-181

- slides for microscope, 163-172

\section{$\mathrm{N}$}

Neck, of capsule, 52

Neckera crispa, 23

Neckera, Crisped, 23

Needles, dissecting, 155

- bent, how to make, 157

Nerve of leaf (mosses), 16, 92

- pseudo, in liverwort leaf, 110 , 139

\section{o}

Oosphere, 38, 43, 128

Operculum, See Lid.

Orthotrichum affine, 56, 80

- Lyellii, 89

- rivulare, 45, 53

- saxatile, 53 
P

Pans for soaking specimens prior to mounting, 165

Papillose leaves, 13, 88, 94

Paraphyllia, 94

Paraphyses, 37

Paroicous plants, 41

Pellia calycina, 116

- epiphylla, 119

Pendulous capsules, 57

Perichætial leaves, 35, 92, 124

Peristome, 68

- action of, 69,72

- double, 71

- markings of, 77

- opening and closing of, 69

- sensitive to atmospheric conditions, 69

- teeth of, 69-74, 77

- - erect when dry, 79

\section{- twisted, 75}

Phascum cuspidatum, 19, 50, 63

Philonotis fontana, 22

Plagiothecium denticulatum, 13

- sylvaticum, 13

Platyscopic lens, 151

Pleurocarpous mosses, 58

Polytrichum. See "Hair-mosses."

- aloides, 44

- commune, 74, 75, 98

Pores in capsules of some mosses, 55

Pottia, Common, 18, 19, 50

Pottia truncatula, 18, 19, 50

Preparation of specimens for mounting, 164

Preparatory mixture, for preparing specimens to mount, 164 Protonema (liverworts), 118

- (mosses), 30, 89

— of bog-mosses, 31

Pterygophyllum lucens, 106

Pyriform capsule, 51
R

Radula complanata, 125, 130

Register of slides, etc., 158

Reproduction, special modes of (liverworts), 136

- - - (mosses), 85

Reproductive organs (liverworts), 121, 131

- - resembling those of bogmosses, 123

- - (mosses), 36, 39

-- leaves surrounding, 35 , 124

- _ - minuteness of, 38

- - position on plant, 41

Ring, 61

Rock-dwellers (mosses), 14

\section{S}

Saucers for soaking specimens in, 155

Scapania nemorosa, 112

Screw-moss, Awl-leaved, 58, 76

- Bird's-claw, 76

- Curly-leaved, 23

- Great Hairy, 23

- Roughish-leaved, 88

- Smaller Hairy, 47, 94

- Wall, 16, 43, 46, 60, 75, 93

"Screw-mosses," 76

Sea, mosses growing near to the, 25

Secund leaves, 13

Sheath (mosses), 43

Seta. See Fruit-stalk.

Slides, cabinet for, 158

- arrangement of, 159

- cleaning of before sealing cells, 171

- register of, 158

Soils, preference of mosses for certain, 23

Spathulate leaf, 16 
Species, number of (liverworts), 104 - - (mosses), 7

Specimens, collection and preservation of, 147

- preparation of, for mounting, 164

Sphagna. See Bog-mosses.

Sphagnum cymbifolium, 21

- squarrosum, 126

Spore-sack, 54

Spores (liverworts), 134

- escape of from capsule, 131

- (mosses), 28

- - escape of, 62,65

Squarrose leaves, 23

Stag's-horn moss, 7

Stipules. See Underleaves.

Stomata. See Pores.

Strumose capsules, 52

Swan-neck Moss, Dwarf, 20, 69

Synoicous plants, 41, 42

\section{T}

Tetraphis pellucida, 70, 86, 89, 120

Thatched roofs, mosses of, 22

Thread-moss, Bud-headed, 87

- Pale-fruited, 89

- Pale-leaved, 25

- Pink-fruited, 33

— Silky Pendulous, 77

- Silvery, 17

- Small-mouthed, 42

Thuidium tamariscinum, 13

Thyme-thread Moss, Dotted, 12, 106

\section{- - Star-leaved, 24}

- Swan-neck, 31, 49, 60, 69, 78

Tortula laripila, 47, 94

- muralis, 16, 43, 46, 60, 75, 93

- papillosa, 88

- ruralis, 23

- subulata, 58, 76
Tree-dwellers (mosses), 22

Trichostomum tortuosum, 23

Trigones, 142

Tympanum, 75

U

Ulota phyllantha, 86, 88

Underleaves (liverworts), 111

Uses of mosses, 97

\section{V}

Vaginula. See Sheath.

Varnishes for sealing cells, 181

Veil (liverworts), 128

- - rupture of, 129

- (mosses), 43, 128

W

Wall-dwellers (mosses), 15

Ward's "Brown cement" for sealing cells, 183

Watchmaker's glass, use of, for dissecting, etc., 155

Water-moss, Greater, 71

Webera annotina, 89

- carnea, 33

- elongata, 52

- nutans, 77

Weisia, Bent-leaved, 22

- Green-tufted, 18

- Pointed-leaved, 24

Weisia mucronata, 24

- tenuis, 15

- viridula, 18

Wing-moss, Pendulous, 93

\section{Y}

Yoke-moss, Green-tufted, 22

Z

Zygodon viridissimus, 22 



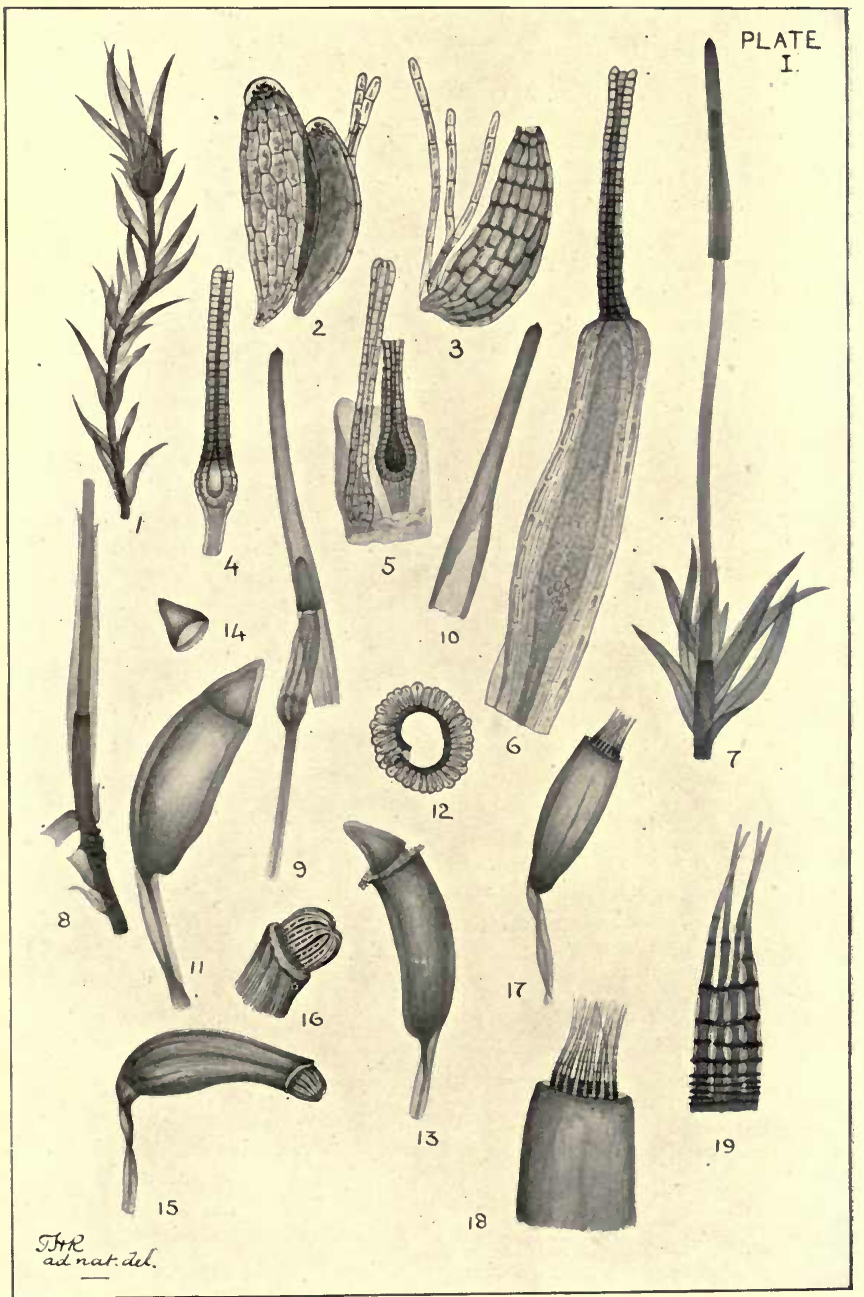





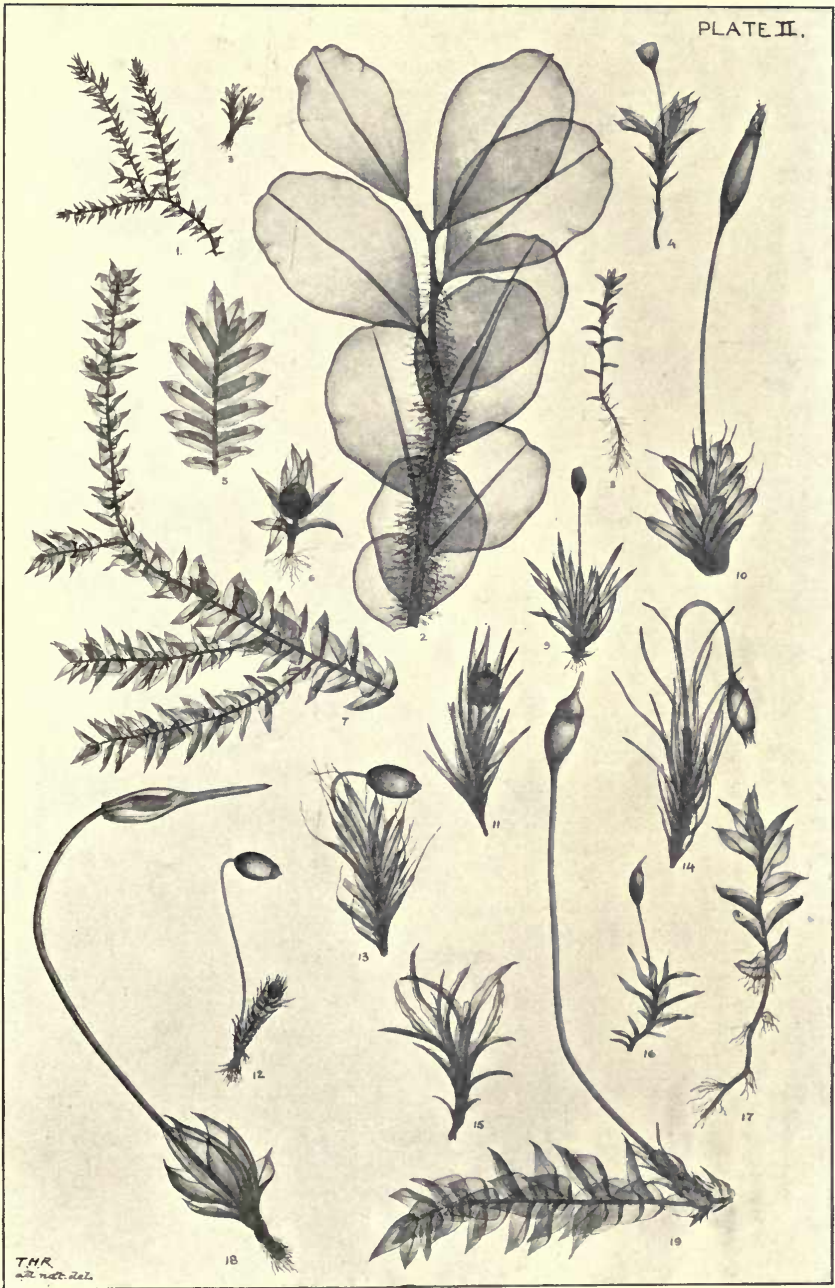





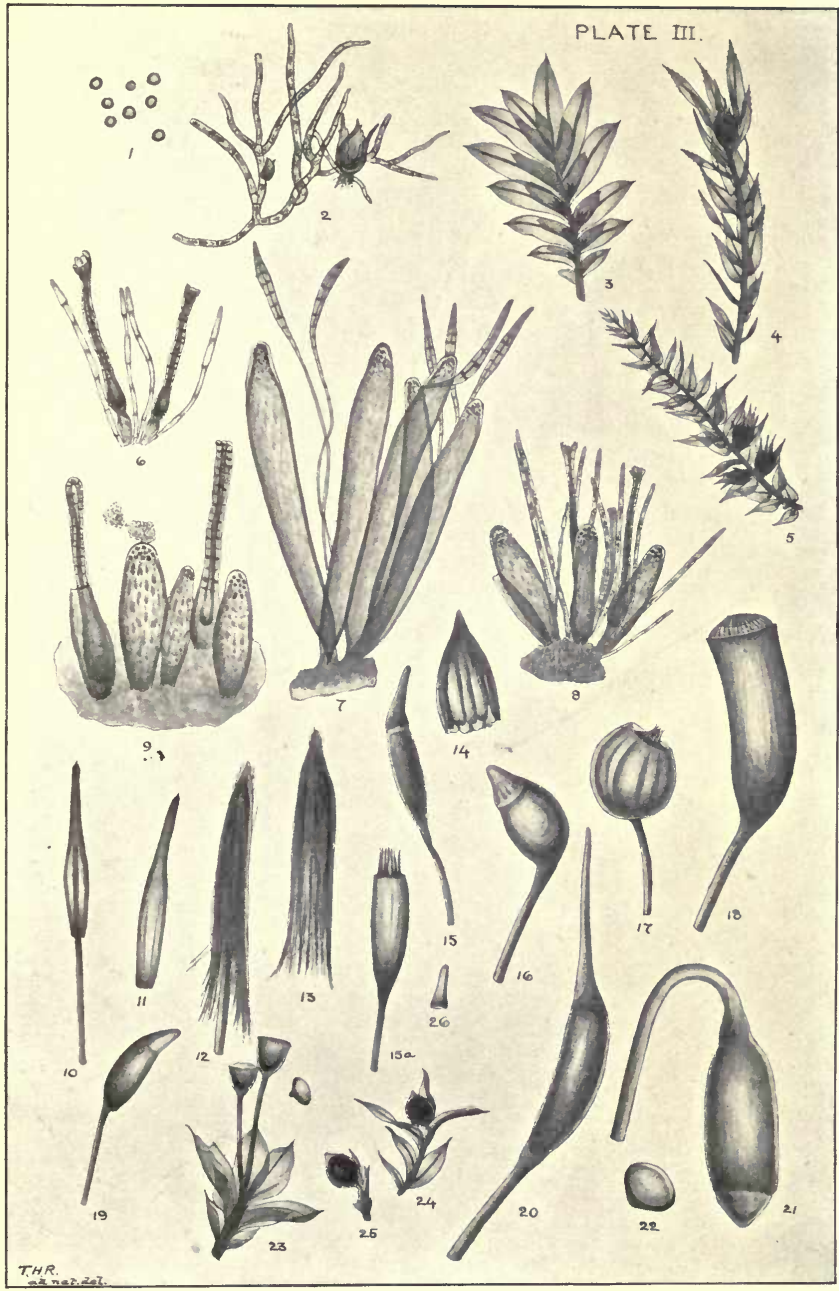





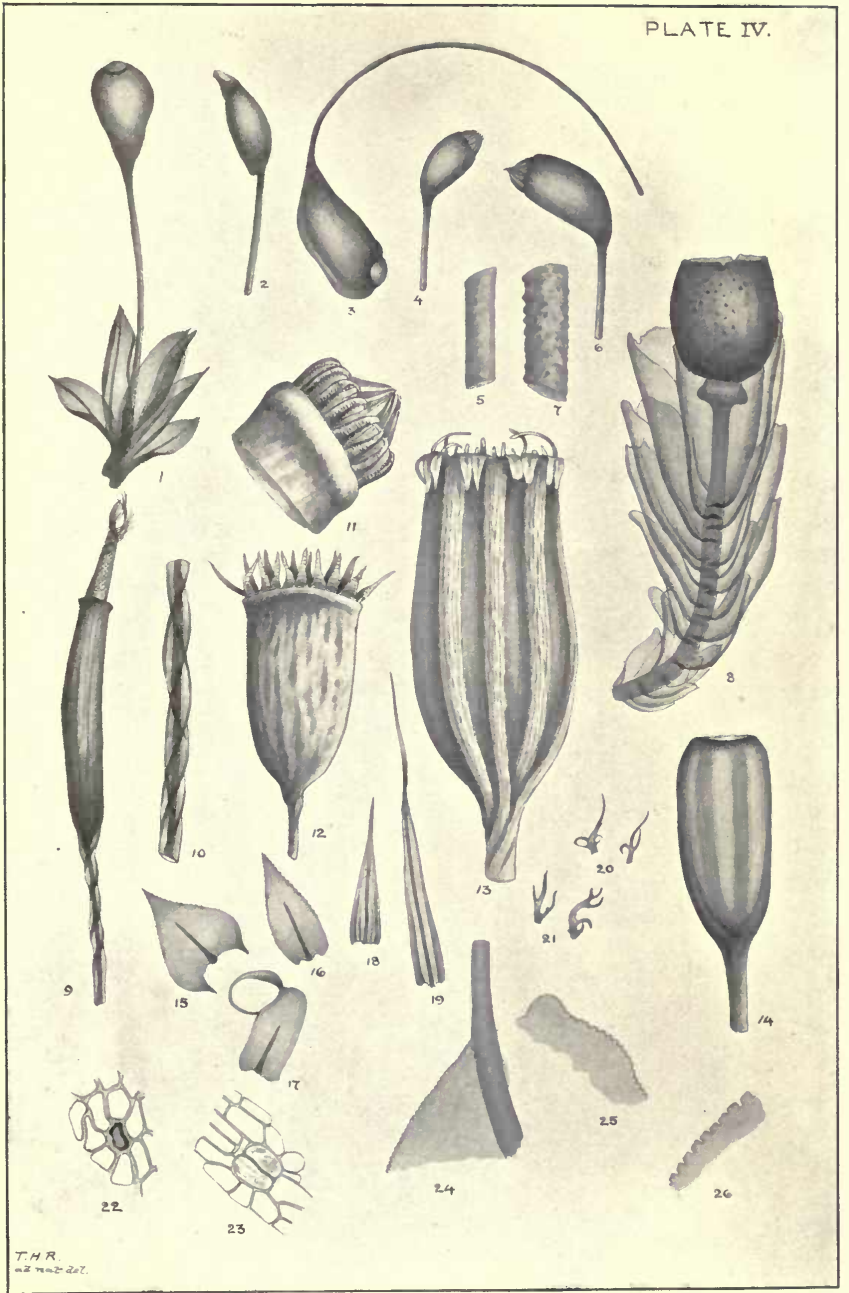




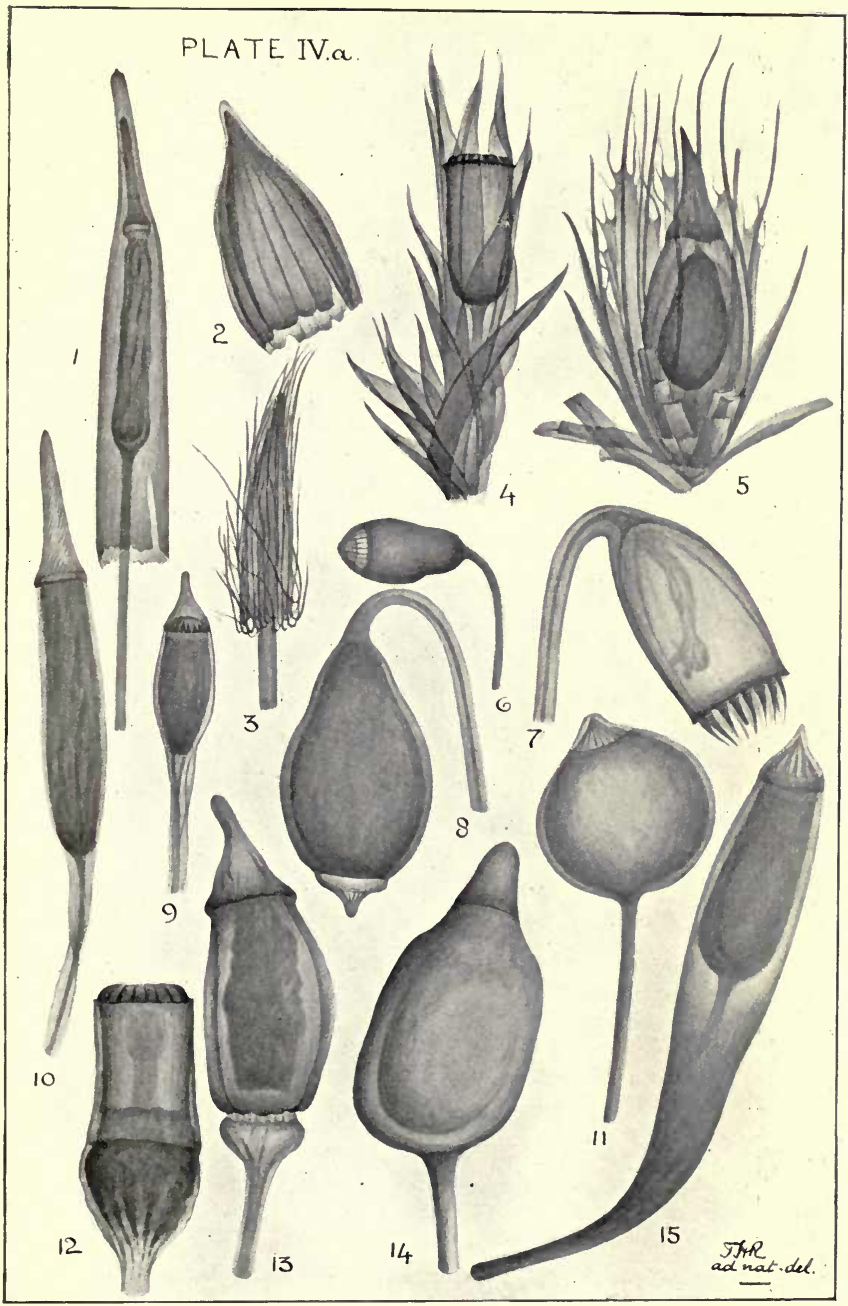





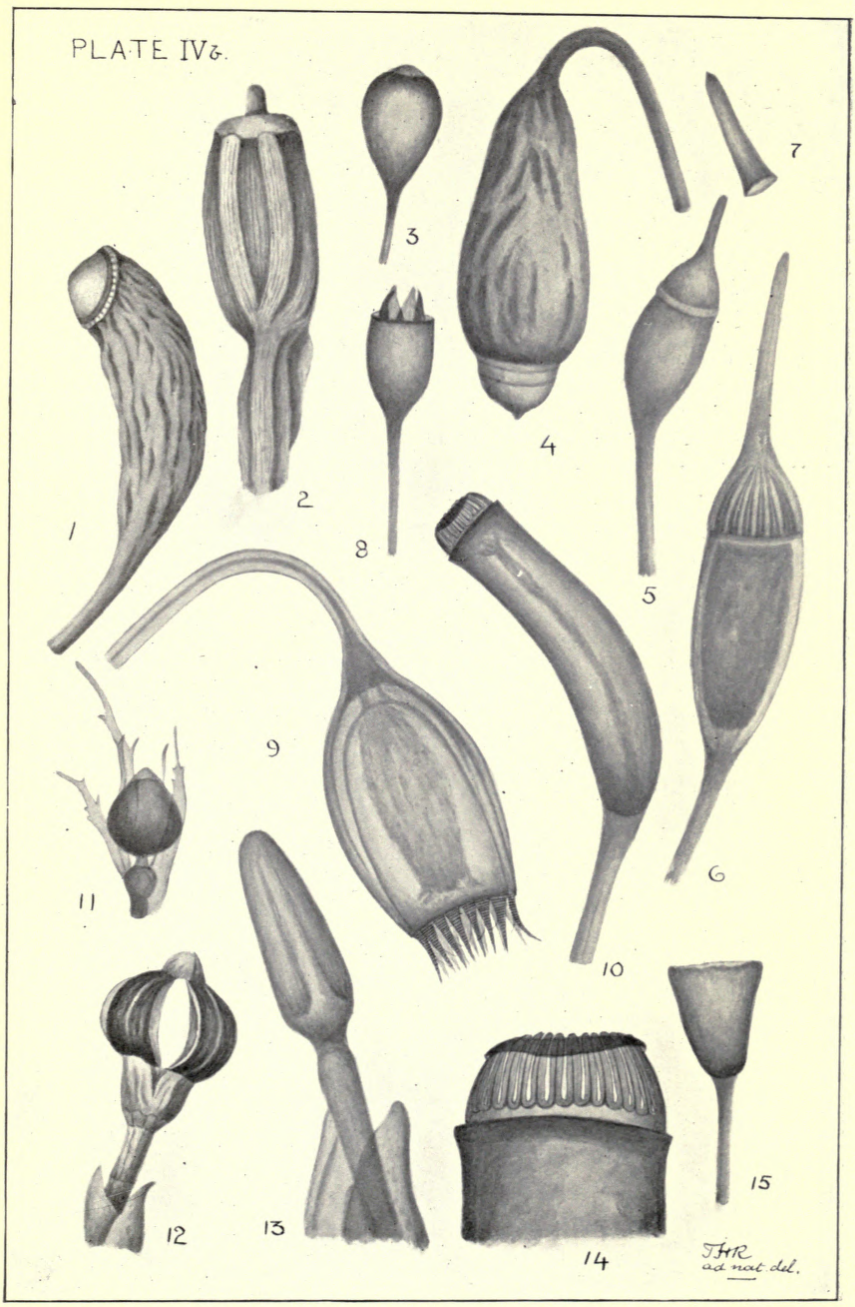





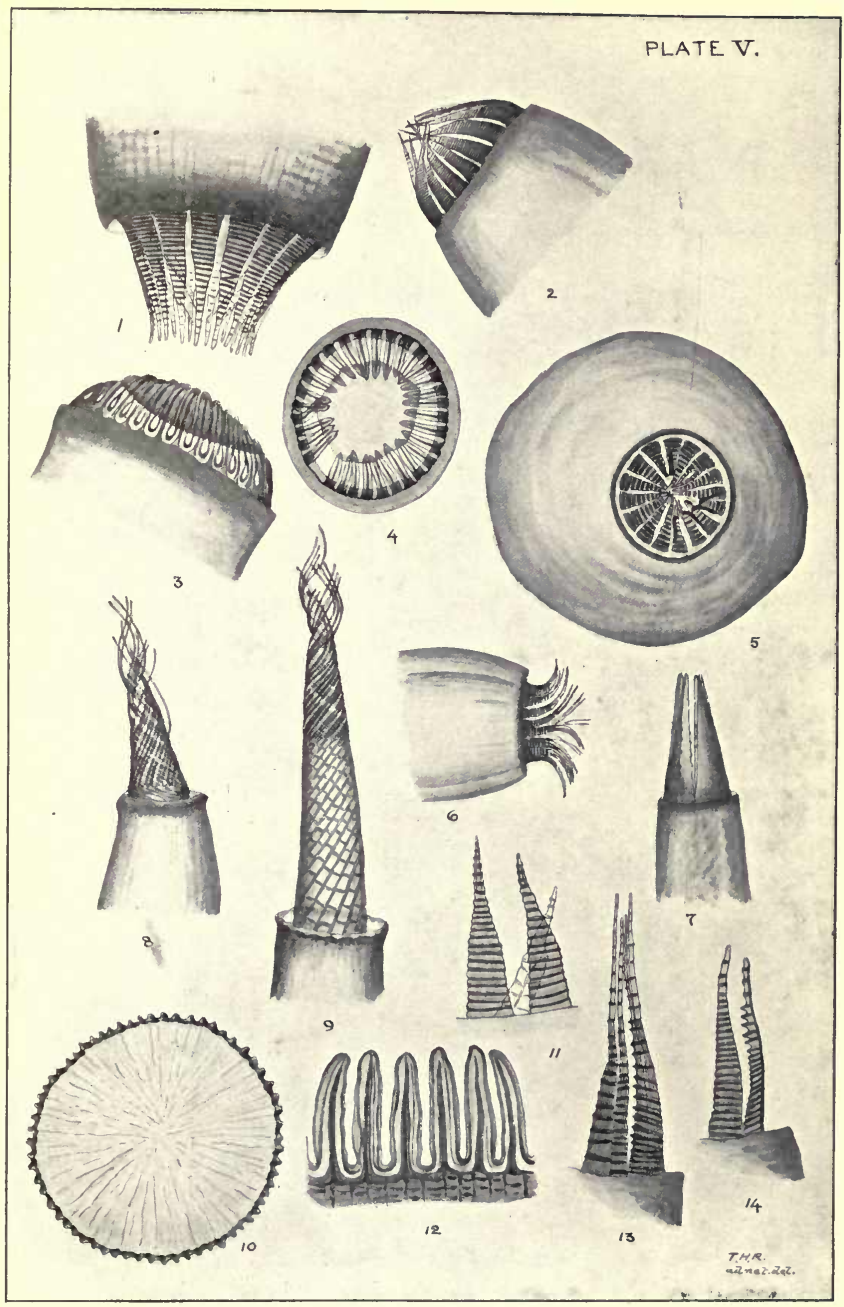





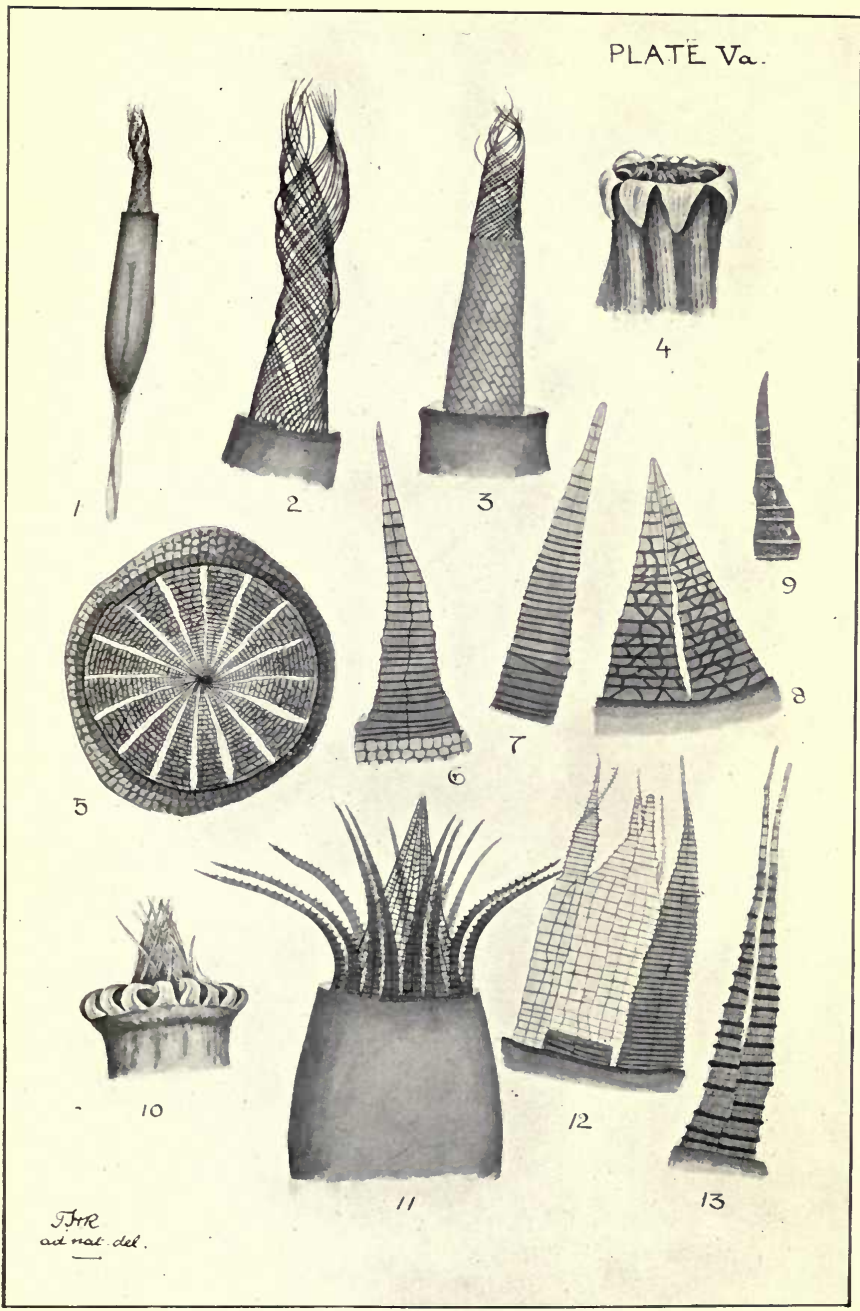





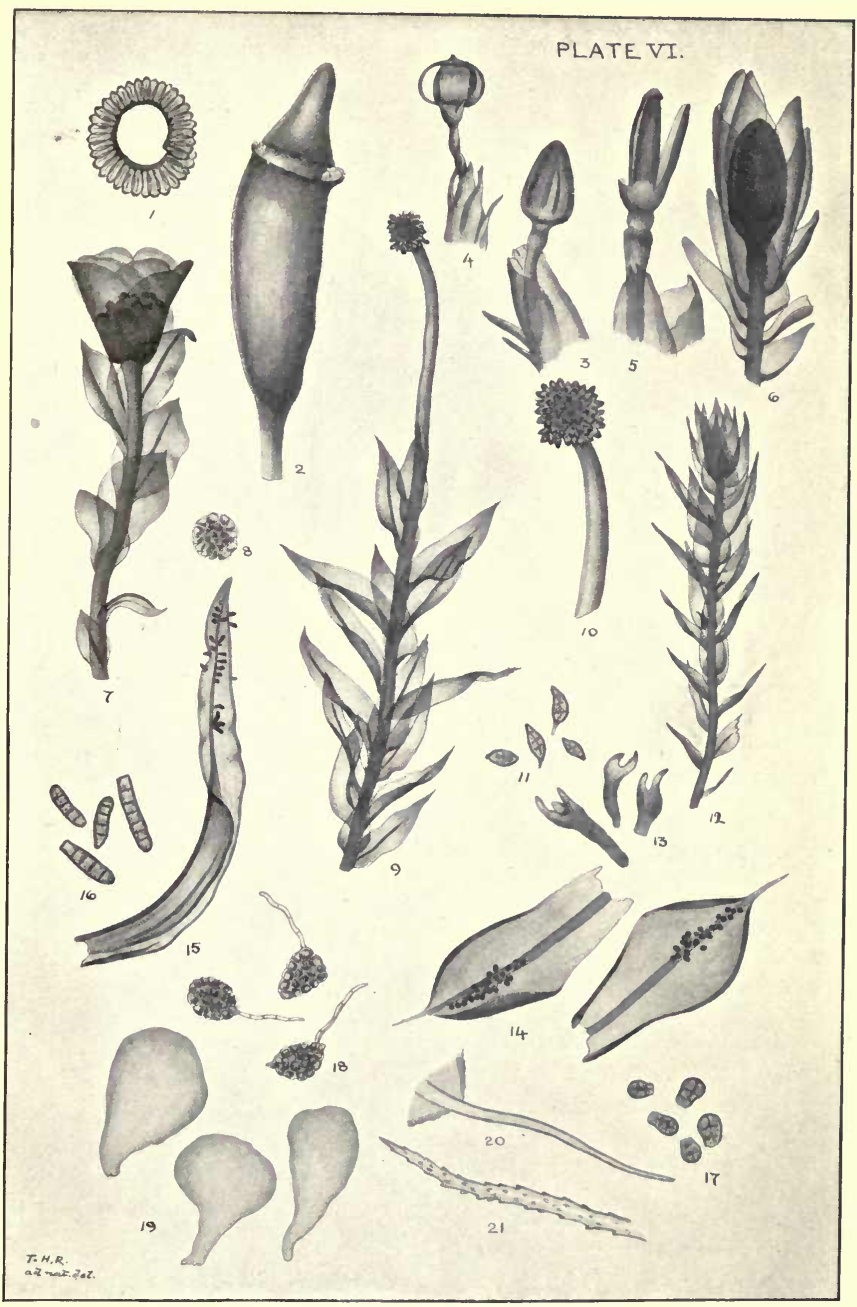





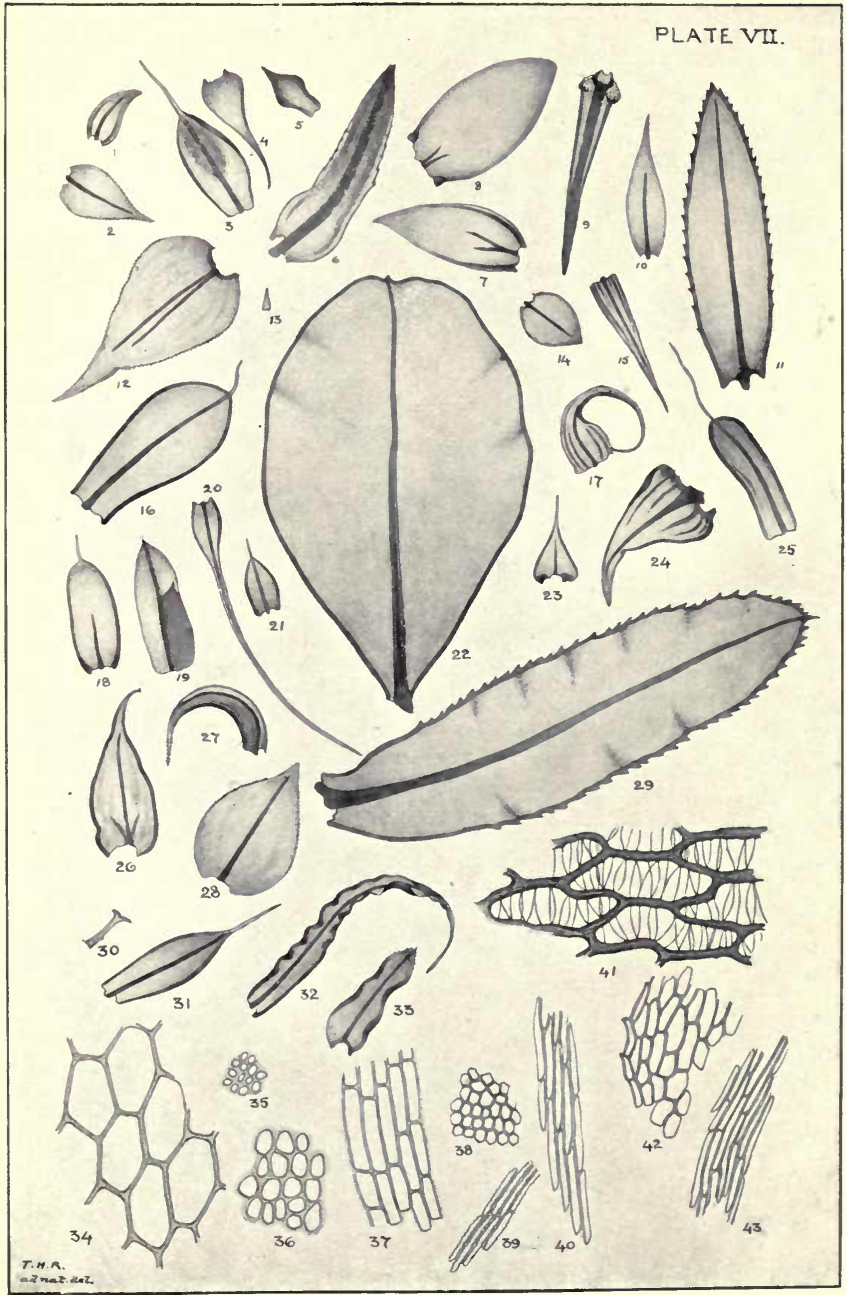





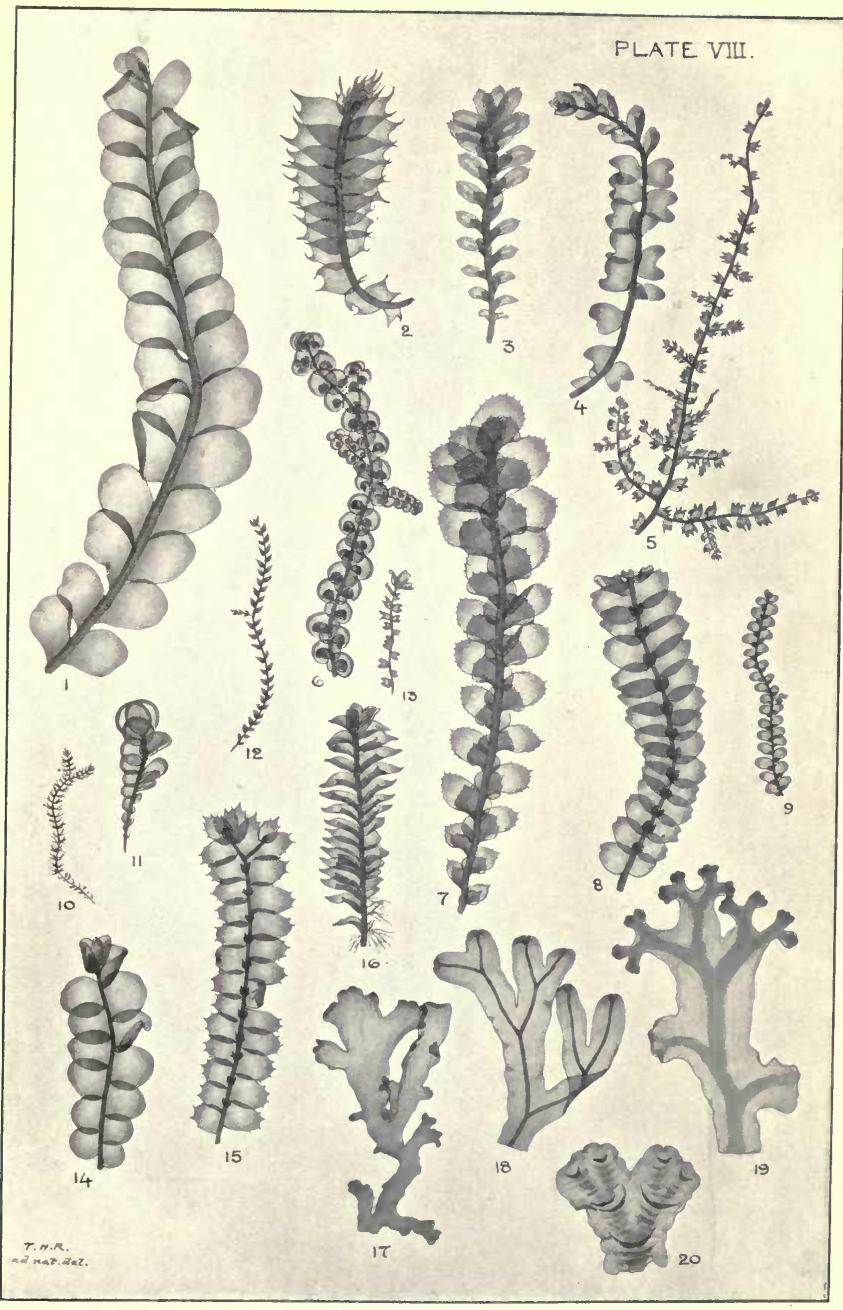





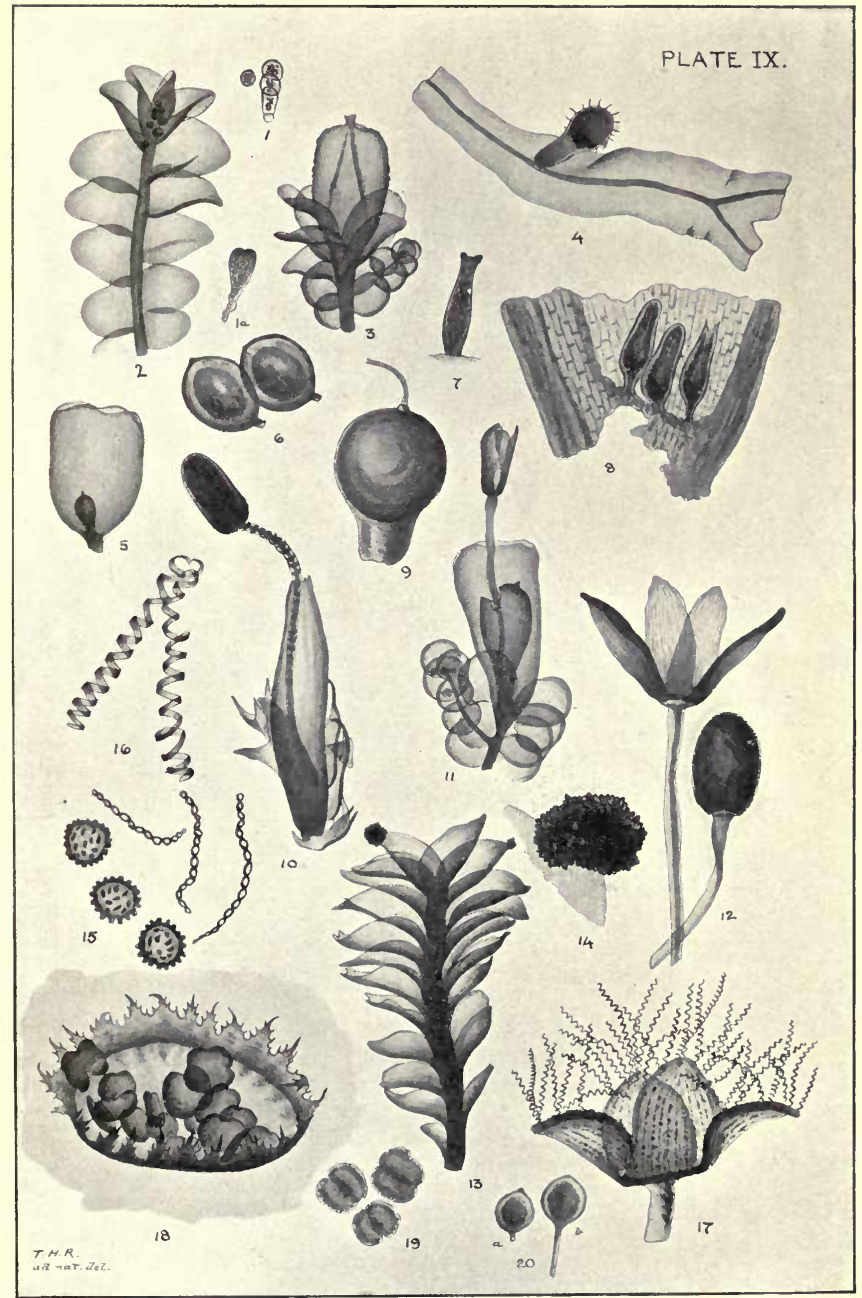





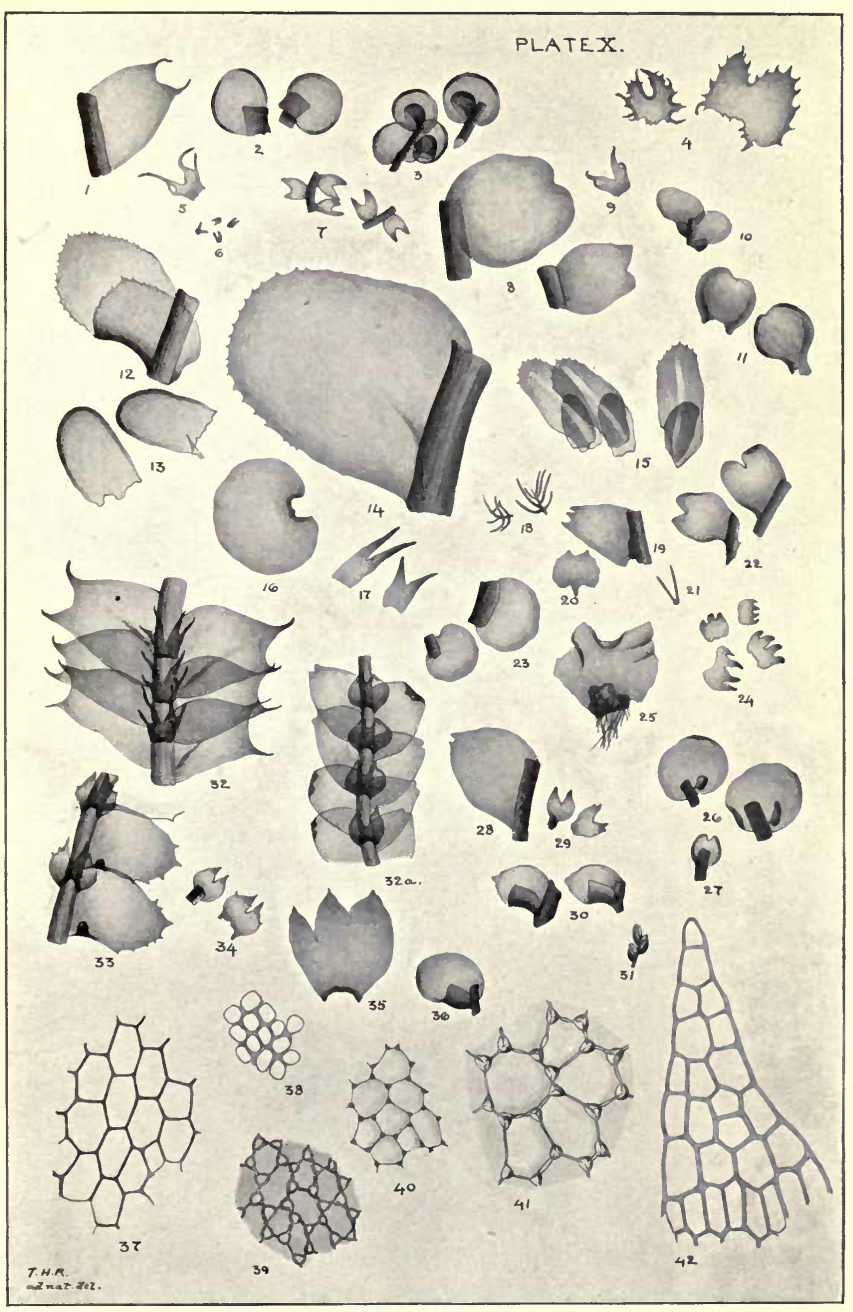





\section{UNIVERSITY OF CALIFORNIA LIBRARY}

\section{Los Angeles}

This book is DUE on the last date stamped below.

\section{REC'D LD-URU}

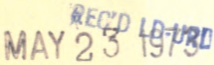

เ

URA JAN $_{3} 379 \%$

DISCHARGE-UKL
OI8I

MAR, 8 PF' 1980

FEB 281990 
